\title{
Oxidative Generation of Boron-Centered Radicals in Carboranes
}

\author{
Harrison A. Mills, Joshua L. Martin, Arnold L. Rheingold and Alexander M. Spokoyny* \\ SUPPLEMENTARY INFORMATION
}

Email: spokoyny@chem.ucla.edu 
Table of Contents

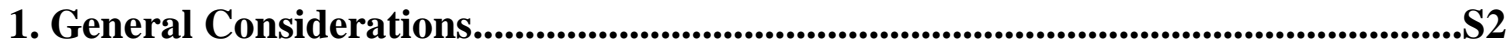

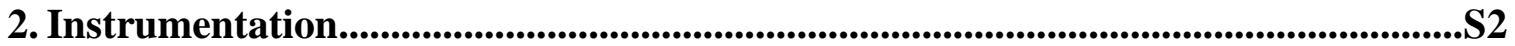

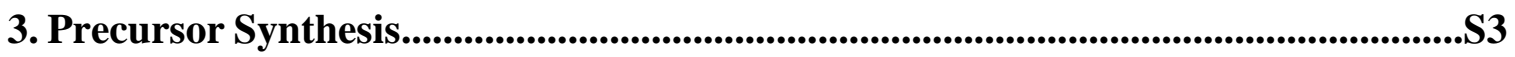

4. Optimization of Borylation Protocol....................................................................S4

5. Reactions with 2a, 2b, and 3-Bpin-oCB..........................................................................S7

6. Cyclic Voltammetry of 3a.............................................................................................S8

7. Optimization of Oxidation Protocol with N-Heterocycles..........................................S9

8. Inhibition by 9,10-Dihydroanthracene...............................................................S10

9. NMR and GC-MS Experiments for Reactions with Electron-Poor and Sterically

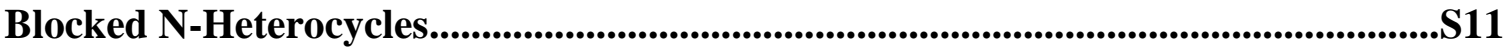

10. General Procedures for Oxidation of 3a...........................................................S14

11. General Procedure for Oxidation of $4 \mathrm{~b}$ or $4 c$..........................................................S17

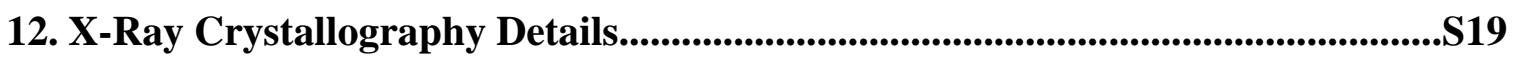

13. References......................................................................................................................S23

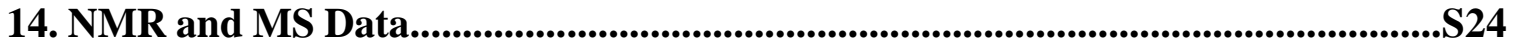

\section{General Considerations}

Meta- $\mathrm{C}_{2} \mathrm{~B}_{10} \mathrm{H}_{12} \quad$ (Katchem), ortho $-\mathrm{C}_{2} \mathrm{~B}_{10} \mathrm{H}_{12} \quad$ (Boron Specialties), and bis(pinacolato)diboron (Oakwood) were sublimed prior to use. Dry dichloromethane was obtained from a Grubbs column with an activated alumina and copper catalyst. $N, N$ dimethylformamide (Sigma-Aldrich) was vacuum distilled over $\mathrm{CaH}_{2}$ and stored in a Teflon valve-sealed flask without molecular sieves. The duration of stirring with $\mathrm{CaH}_{2}$ is noted to be quite critical. DMF used for the synthesis of 9-Bpin-oCB (2b) was stirred with $\mathrm{CaH}_{2}$ overnight while DMF used for 9-Bpin-mCB (2a) was stirred with $\mathrm{CaH}_{2}$ for 4-6 hours. DPPF (Oakwood) was recrystallized for $24 \mathrm{~h}$ from benzene layered with pentane prior to use. Palladium precatalysts were prepared according to reference $1 . \mathrm{Cs}_{2} \mathrm{CO}_{3}$ (Fisher) was used as received and stored in an $\mathrm{N}_{2}$-filled glovebox. Acetic acid was dried by distilling $50 \mathrm{~mL}$ from $1 \mathrm{~g} \mathrm{CrO}_{3}$ with $2 \mathrm{~mL}$ of acetic anhydride and stored under argon. (9-Se-oCB $)_{2}$ used in the synthesis of $\mathbf{5 e}$ was prepared by making the corresponding selenol (reference 2) and oxidizing it in refluxing methanol exposed to air for three days. Benzothiazole and 4-methylquinoline were vacuum distilled prior to use. All solvents used for cross-couplings and oxidations were deoxygenated by sparging with argon gas before use. All other chemicals were used as received.

Plastic-backed Baker-flex Silica Gel IB2-F TLC plates were used for thin layer chromatography. Silica used for flash column chromatography was SiliaFlash $®$ G60 60$200 \mu \mathrm{m}$ (70-230 mesh) purchased from Silicycle. TLC samples for carborane-containing compounds were stained with 1 wt. $\% \mathrm{PdCl}_{2}$ in $6 \mathrm{M} \mathrm{HCl}$ and developed with heat.

\section{Instrumentation}

${ }^{1} \mathrm{H},{ }^{13} \mathrm{C}\left\{{ }^{1} \mathrm{H}\right\},{ }^{11} \mathrm{~B},{ }^{11} \mathrm{~B}\left\{{ }^{1} \mathrm{H}\right\},{ }^{19} \mathrm{~F},{ }^{19} \mathrm{~F}\left\{{ }^{1} \mathrm{H}\right\},{ }^{77} \mathrm{Se}$, and ${ }^{125} \mathrm{Te}$ NMR spectra were recorded on either a Bruker DRX500 or Bruker AVIII 400 spectrometer in ambient conditions unless stated otherwise. MestReNova v6.0.2-5475 software was used to process the FID data and visualize the spectra. ${ }^{1} \mathrm{H}$ and ${ }^{13} \mathrm{C}\left\{{ }^{1} \mathrm{H}\right\}$ NMR spectra were referenced to residual solvent 
resonances in deuterated solvents $\left(\mathrm{CDCl}_{3}:{ }^{1} \mathrm{H}, 7.26 \mathrm{ppm} ;{ }^{13} \mathrm{C}, 77.16 \mathrm{ppm}\right.$, Note: due to high humidity $\mathrm{H}_{2} \mathrm{O}$ resonances are often present) and are reported relative to tetramethylsilane $(\delta=0 \mathrm{ppm}) .{ }^{11} \mathrm{~B}$ and ${ }^{11} \mathrm{~B}\left\{{ }^{1} \mathrm{H}\right\}$ NMR spectra were referenced externally to $\mathrm{Et}_{2} \mathrm{O} \cdot \mathrm{BF}_{3}(\delta=0$ ppm). ${ }^{19} \mathrm{~F}$ and ${ }^{19} \mathrm{~F}\left\{{ }^{1} \mathrm{H}\right\}$ NMR spectra were referenced externally to fluorobenzene $(\delta=-$ $113.15 \mathrm{ppm}) .{ }^{77} \mathrm{Se}$ NMR spectra were referenced externally to diphenyldiselenide $(\delta=$ $463.15 \mathrm{ppm}) .{ }^{125} \mathrm{Te}$ NMR spectra were referenced externally to diphenylditelluride in tetrahydrofuran at room temperature $(\delta=408 \mathrm{ppm})$

High Resolution Gas Chromatography Mass Spectrometry (HRGC-MS) measurements were carried out using an Agilent Model 7693 Autosampler, 7890B Gas Chromatograph, and 7250 Q-TOF Mass Selective Detector in the Electron Ionization mode. Samples injection was carried out on an Agilent HP5-MS column with dimensions $30 \mathrm{~m}$ x $250 \mu \mathrm{m}$ x $0.25 \mu \mathrm{m}$. Ultra High Purity Grade He (Airgas) was used as a carrier gas. Data collection and analysis were performed using Mass Hunter Acquisition and Qualitative Analysis software (Agilent).

DART-MS spectra were collected on a Thermo Exactive Plus MSD (Thermo Scientific) equipped with an ID-CUBE ion source and a Vapur Interface (IonSense). Both the source and MSD were controlled by Excalibur v. 3.0. The analyte was spotted onto OpenSpot sampling cards (IonSense). Ionization was accomplished using $\mathrm{He}$ plasma with no additional ionization agents. Mass calibration was carried out using Pierce LTQ Velos ESI (+) and (-) Ion calibration solutions (Thermo Fisher Scientific).

Elemental analysis of compounds 2a and 5f was performed by Atlantic Microlab.

\section{Precursor Synthesis}

\section{9-I-1,7-dicarba-closo-dodecaborane (1a)}

Meta- $\mathrm{C}_{2} \mathrm{~B}_{10} \mathrm{H}_{12}$ (1.44 g, $\left.10 \mathrm{mmol}\right)$ was added to an oven-dried Schlenk flask capped with a rubber septum and evacuated/backfilled with $\mathrm{N}_{2}$ three times. $\mathrm{I}_{2}(2.54 \mathrm{~g}, 10 \mathrm{mmol})$ was added under a positive $\mathrm{N}_{2}$ flow before the addition of dry $\mathrm{CH}_{2} \mathrm{Cl}_{2}(50 \mathrm{~mL})$ via cannula. $\mathrm{AlCl}_{3}(0.199 \mathrm{~g}, 15 \mathrm{~mol} \%)$ was added to the stirring solution under a positive $\mathrm{N}_{2}$ flow before the rubber septum was replaced with a greased ground-glass stopper. The reaction mixture was then left to stir overnight at room temperature. Upon completion of the reaction, determined by GC-MS, the reaction was slowly quenched by the addition of distilled $\mathrm{H}_{2} \mathrm{O}$ $(20 \mathrm{~mL})$, yielding a cloudy suspension. The opaque organic layer was separated from the aqueous layer and the aqueous layer was extracted with $\mathrm{CH}_{2} \mathrm{Cl}_{2}(2 \times 10 \mathrm{~mL})$. The organic portions were combined and dried with $\mathrm{MgSO}_{4}$ resulting in a clear, colorless solution. The solution was then filtered through a pad of Celite on a fritted funnel and the $\mathrm{CH}_{2} \mathrm{Cl}_{2}$ was removed under reduced pressure to yield a white solid that was further purified by sublimation at $100{ }^{\circ} \mathrm{C}$ to produce the title compound as a white solid.

Yields and spectra are in agreement to previously reported syntheses (reference 3) 


\section{9-I-1,2-dicarba-closo-dodecaborane (1b)}

Prepared in an analogous method to $\mathbf{1 a}$, where instead ortho- $\mathrm{C}_{2} \mathrm{~B}_{10} \mathrm{H}_{12}$ was used. Yields and spectra are in agreement to previously reported syntheses (reference 3 )

\section{Optimization of Borylation Protocol}

Optimizations were originally performed using I-oCB and subsequently transferred to I$\mathrm{mCB}$ for final optimizations. Optimization was used to identify a suitable catalyst (ML), base $(\mathbf{B})$, solvent $(\mathbf{S})$, and temperature $(\mathbf{T})$ required to achieve optimal conversion to Bpin$\mathrm{mCB}$. Catalyst, $\mathrm{B}_{2} \mathrm{Pin}_{2}$, and I-mCB were added to an oven-dried reaction tube and sealed with a PTFE septum cap. The reaction tube was evacuated and backfilled with $\mathrm{N}_{2}$ three times before transferring into an $\mathrm{N}_{2}$-filled glovebox. Under an inert atmosphere, dry base and solvent were added and the reaction tube was brought out and placed in a preheated oil bath when heating was necessary. Reaction progress was monitored by using a syringe to take an aliquot to be analyzed with HRGC-MS. Note: Later optimizations included the addition of deoxygenated $\mathrm{H}_{2} \mathrm{O}$ prior to heating. I-mCB was used in later optimizations to avoid deboronation present when using I-oCB.

Table S1. Base screen w/ DMF for solvent and [dppf-Pd-G3] as catalyst

\begin{tabular}{|c|c|c|c|c|c|c|c|}
\hline \multirow[t]{2}{*}{ Entry \# } & \multicolumn{5}{|c|}{ Experimental Conditions } & \multicolumn{2}{|c|}{ \% conversion by HRGC-MS } \\
\hline & ML & B & $\mathbf{S}$ & $\mathbf{T}$ & Time & $2 \mathrm{~b}$ & $1 \mathrm{~b}$ \\
\hline 1 & [dppf-Pd-G3], $5 \mathrm{~mol} \%$ & $\mathrm{CsF}, 1 \mathrm{eq}$ & DMF & $25^{\circ} \mathrm{C}$ & $3 \mathrm{~h}$ & 11 & 89 \\
\hline 2 & [dppf-Pd-G3], $5 \mathrm{~mol} \%$ & $\mathrm{Cs}_{2} \mathrm{CO}_{3}, 1 \mathrm{eq}$ & DMF & $25^{\circ} \mathrm{C}$ & $3 \mathrm{~h}$ & 37.5 & 62.5 \\
\hline 3 & [dppf-Pd-G3], $5 \mathrm{~mol} \%$ & $\mathrm{~K}^{\mathrm{t}} \mathrm{BuO}, 1 \mathrm{eq}$ & DMF & $25^{\circ} \mathrm{C}$ & $3 \mathrm{~h}$ & 32 & 68 \\
\hline 4 & [dppf-Pd-G3], $5 \mathrm{~mol} \%$ & $\mathrm{KF}, 1 \mathrm{eq}$ & DMF & $25^{\circ} \mathrm{C}$ & $3 \mathrm{~h}$ & $<1$ & $>99$ \\
\hline 5 & [dppf-Pd-G3], $5 \mathrm{~mol} \%$ & KOAc, 1 eq & DMF & $25^{\circ} \mathrm{C}$ & $3 \mathrm{~h}$ & 0 & 100 \\
\hline 6 & [dppf-Pd-G3], $5 \mathrm{~mol} \%$ & $\mathrm{~K}_{3} \mathrm{PO}_{4}, 1 \mathrm{eq}$ & DMF & $25^{\circ} \mathrm{C}$ & $3 \mathrm{~h}$ & 5 & 95 \\
\hline 7 & [dppf-Pd-G3], $5 \mathrm{~mol} \%$ & $\mathrm{~K}_{2} \mathrm{CO}_{3}, 1 \mathrm{eq}$ & DMF & $25^{\circ} \mathrm{C}$ & $3 \mathrm{~h}$ & 2 & 98 \\
\hline 8 & [dppf-Pd-G3], $5 \mathrm{~mol} \%$ & $\mathrm{KH}_{2} \mathrm{PO}_{4}, 1 \mathrm{eq}$ & DMF & $25^{\circ} \mathrm{C}$ & $3 \mathrm{~h}$ & 0 & 100 \\
\hline 9 & [dppf-Pd-G3], $5 \mathrm{~mol} \%$ & $\mathrm{NaOMe}, 1 \mathrm{eq}$ & DMF & $25^{\circ} \mathrm{C}$ & $3 \mathrm{~h}$ & 13.5 & 86.5 \\
\hline 10 & [dppf-Pd-G3], $5 \mathrm{~mol} \%$ & LiOAc, 1 eq & DMF & $25^{\circ} \mathrm{C}$ & $3 \mathrm{~h}$ & 0 & 100 \\
\hline
\end{tabular}

Table S2. Solvent screen w/ $\mathrm{Cs}_{2} \mathrm{CO}_{3}$ for base and [dppf-Pd-G3] as catalyst

\begin{tabular}{|c|c|c|c|c|c|c|c|}
\hline \multirow[t]{2}{*}{ Entry \# } & \multicolumn{5}{|c|}{ Experimental Conditions } & \multicolumn{2}{|c|}{ \% conversion by HRGC-MS } \\
\hline & ML & B & $\mathbf{S}$ & $\mathbf{T}$ & Time & $2 \mathbf{b}$ & 1b \\
\hline 1 & [dppf-Pd-G3], $5 \mathrm{~mol} \%$ & $\mathrm{Cs}_{2} \mathrm{CO}_{3}, 1 \mathrm{eq}$ & DMF & $25^{\circ} \mathrm{C}$ & $6 \mathrm{~h}$ & 55 & 45 \\
\hline 2 & [dppf-Pd-G3], $5 \mathrm{~mol} \%$ & $\mathrm{Cs}_{2} \mathrm{CO}_{3}, 1 \mathrm{eq}$ & THF & $25^{\circ} \mathrm{C}$ & $6 \mathrm{~h}$ & 0 & 100 \\
\hline 3 & [dppf-Pd-G3], $5 \mathrm{~mol} \%$ & $\mathrm{Cs}_{2} \mathrm{CO}_{3}, 1 \mathrm{eq}$ & Dioxane & $25^{\circ} \mathrm{C}$ & $6 \mathrm{~h}$ & 0 & 100 \\
\hline 4 & [dppf-Pd-G3], $5 \mathrm{~mol} \%$ & $\mathrm{Cs}_{2} \mathrm{CO}_{3}, 1 \mathrm{eq}$ & Toluene & $25^{\circ} \mathrm{C}$ & $6 \mathrm{~h}$ & 0 & 100 \\
\hline 5 & [dppf-Pd-G3], $5 \mathrm{~mol} \%$ & $\mathrm{Cs}_{2} \mathrm{CO}_{3}, 1 \mathrm{eq}$ & DMAc & $25^{\circ} \mathrm{C}$ & $6 \mathrm{~h}$ & 10 & 90 \\
\hline 6 & [dppf-Pd-G3], $5 \mathrm{~mol} \%$ & $\mathrm{Cs}_{2} \mathrm{CO}_{3}, 1 \mathrm{eq}$ & DME & $25^{\circ} \mathrm{C}$ & $6 \mathrm{~h}$ & 15 & 85 \\
\hline
\end{tabular}

Table S3. Catalyst Loading Screen

\begin{tabular}{|c|c|c|c|c|c|c|c|}
\hline \multirow{2}{*}{ Entry \# } & \multicolumn{3}{|c|}{ Experimental Conditions } & \% conversion by HRGC-MS \\
\cline { 2 - 9 } & ML & B & S & T & Time & 2b & 1b \\
\hline 1 & {$[d p p f-P d-G 3], 2.5 \mathrm{~mol} \%$} & $\mathrm{Cs}_{2} \mathrm{CO}_{3}, 1 \mathrm{eq}$ & $\mathrm{DMF}$ & $25^{\circ} \mathrm{C}$ & $6 \mathrm{~h}$ & 53 & 47 \\
\hline 2 & {$[\mathrm{dppf}-\mathrm{Pd}-\mathrm{G} 3], 5 \mathrm{~mol} \%$} & $\mathrm{Cs}_{2} \mathrm{CO}_{3}, 1 \mathrm{eq}$ & $\mathrm{DMF}$ & $25^{\circ} \mathrm{C}$ & $6 \mathrm{~h}$ & 61 & 39 \\
\hline 3 & {$[\mathrm{dppf}-\mathrm{Pd}-\mathrm{G} 3], 7.5 \mathrm{~mol} \%$} & $\mathrm{Cs}_{2} \mathrm{CO}_{3}, 1 \mathrm{eq}$ & $\mathrm{DMF}$ & $25^{\circ} \mathrm{C}$ & $6 \mathrm{~h}$ & 50 & 50 \\
\hline 4 & {$[\mathrm{dppf}-\mathrm{Pd}-\mathrm{G} 3], 10 \mathrm{~mol} \%$} & $\mathrm{Cs}_{2} \mathrm{CO}_{3}, 1 \mathrm{eq}$ & $\mathrm{DMF}$ & $25^{\circ} \mathrm{C}$ & $6 \mathrm{~h}$ & 38 & 62 \\
\hline
\end{tabular}


Table S4. Condition Screen for I-mCB as substrate

\begin{tabular}{|c|c|c|c|c|c|c|c|c|}
\hline \multirow{2}{*}{$\begin{array}{c}\text { Entry } \\
\#\end{array}$} & \multicolumn{5}{|c|}{ Experimental Conditions } & \multicolumn{3}{|c|}{$\%$ conversion by HRGC-MS } \\
\hline & ML & B & $\mathbf{S}$ & $\mathbf{T}$ & Time & $\mathbf{2 a}$ & $\mathbf{1 a}$ & $\mathrm{mCB}$ \\
\hline 1 & [dppf-Pd-G3], 5 mol\% & $\mathrm{Cs}_{2} \mathrm{CO}_{3}, 1 \mathrm{eq}$ & DMF & $25^{\circ} \mathrm{C}$ & $20 \mathrm{~h}$ & 51 & 48 & $<1$ \\
\hline 2 & [dppf-Pd-G3], $5 \mathrm{~mol} \%$ & $\mathrm{Cs}_{2} \mathrm{CO}_{3}, 1 \mathrm{eq}$ & DMF & $50^{\circ} \mathrm{C}$ & $6 \mathrm{~h}$ & 56 & 38 & 7 \\
\hline 3 & [dppf-Pd-G3], $5 \mathrm{~mol} \%$ & $\begin{array}{l}\mathrm{Cs}_{2} \mathrm{CO}_{3}, 1 \mathrm{eq} \\
\mathrm{Et}_{3} \mathrm{~N}, 0.25 \mathrm{eq}\end{array}$ & DMF & $50^{\circ} \mathrm{C}$ & $6 \mathrm{~h}$ & 53 & 42 & 5 \\
\hline 4 & [dppf-Pd-G3], $5 \mathrm{~mol} \%$ & $\mathrm{Cs}_{2} \mathrm{CO}_{3}, 1.5 \mathrm{eq}$ & DMF & $50^{\circ} \mathrm{C}$ & $6 \mathrm{~h}$ & 68 & 26 & 7 \\
\hline 5 & [dppf-Pd-G3], $5 \mathrm{~mol} \%$ & $\mathrm{Cs}_{2} \mathrm{CO}_{3}, 2 \mathrm{eq}$ & DMF & $50^{\circ} \mathrm{C}$ & $6 \mathrm{~h}$ & 72 & 22 & 6 \\
\hline
\end{tabular}

Table S5. Effect of $\mathrm{H}_{2} \mathrm{O}$ on cross coupling

\begin{tabular}{|c|c|c|c|c|c|c|c|}
\hline \multirow{2}{*}{$\begin{array}{c}\text { Entry } \\
\quad \#\end{array}$} & \multicolumn{4}{|c|}{ Experimental Conditions } & \multicolumn{3}{|c|}{ \% conversion by HRGC-MS } \\
\hline & ML & B & $\mathbf{S}$ & Time & $\mathbf{2 a}$ & 1a & mCB \\
\hline 1 & $\begin{array}{l}\text { [dppf-Pd-G3], } \\
5 \mathrm{~mol} \%\end{array}$ & $\begin{array}{c}\mathrm{Cs}_{2} \mathrm{CO}_{3}(\text { from } \\
\text { glovebox }), 2.5 \mathrm{eq}\end{array}$ & DMF & $8 \mathrm{~h}$ & 68 & 19 & 13 \\
\hline 2 & $\begin{array}{c}\text { [dppf-Pd-G3], } \\
5 \mathrm{~mol} \%\end{array}$ & $\begin{array}{c}\mathrm{Cs}_{2} \mathrm{CO}_{3} \text { (from } \\
\text { dessicator), } 2.5 \mathrm{eq}\end{array}$ & DMF & $8 \mathrm{~h}$ & 72 & 17 & 11 \\
\hline 3 & $\begin{array}{c}\text { [dppf-Pd-G3], } \\
5 \mathrm{~mol} \%\end{array}$ & $\mathrm{Cs}_{2} \mathrm{CO}_{3}(\mathrm{gb}), 2.5 \mathrm{eq}$ & $\begin{array}{c}\text { DMF, } 5 \%(\mathrm{v} / \mathrm{v}) \\
\mathrm{H}_{2} \mathrm{O}\end{array}$ & $2 \mathrm{~h}$ & 67 & 23 & 10 \\
\hline 4 & $\begin{array}{l}\text { [dppf-Pd-G3], } \\
5 \mathrm{~mol} \%\end{array}$ & $\mathrm{Cs}_{2} \mathrm{CO}_{3}(\mathrm{gb}), 2.5 \mathrm{eq}$ & $\begin{array}{c}\text { DMF, } \\
20 \%(\mathrm{v} / \mathrm{v}) \mathrm{H}_{2} \mathrm{O}\end{array}$ & $2 \mathrm{~h}$ & 58 & 37 & 5 \\
\hline
\end{tabular}

\section{Representative HRGC-MS of Crude Reaction Mixture for 2a}

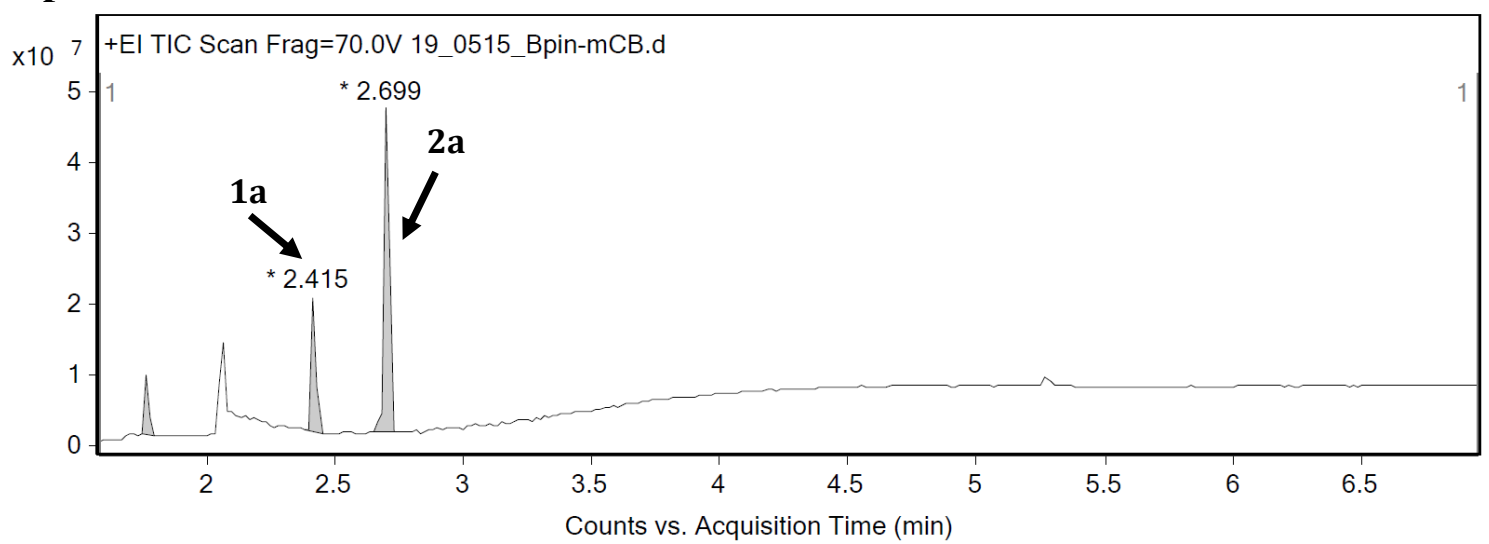

\section{9-B(OCMe2 $\left.\mathrm{CMe}_{2} \mathrm{O}\right)$-1,7-dicarba-closo-dodecaborane (2a, 5 mmol scale)}

9-I-mCB (1.35 g, $5 \mathrm{mmol}), \mathrm{B}_{2} \mathrm{pin}_{2}(2.0 \mathrm{~g}, 7.5 \mathrm{mmol}, 1.5 \mathrm{eq})$, and dppf-Pd-G3 precatalyst (231 mg, $5 \mathrm{~mol} \%$ ) were added to an oven-dried Schlenk flask and capped with a rubber septum. The flask was evacuated and backfilled with $\mathrm{N}_{2}$ three times and transferred into an $\mathrm{N}_{2}$-filled glovebox where $\mathrm{Cs}_{2} \mathrm{CO}_{3}(4.13 \mathrm{~g}, 12.5 \mathrm{mmol}, 2.5 \mathrm{eq})$ and DMF (18.75 mL) were added. The flask was then transferred outside of the glovebox, where deoxygenated $\mathrm{H}_{2} \mathrm{O}$ $(5 \% \mathrm{v} / \mathrm{v}, 0.94 \mathrm{~mL})$ was added and the reaction was allowed to stir for $2 \mathrm{~h}$ at $50{ }^{\circ} \mathrm{C}$. After 2 $\mathrm{h}$, the reaction was quenched by the addition of distilled $\mathrm{H}_{2} \mathrm{O}(200 \mathrm{~mL})$ to yield a cloudy/tan solution. Upon addition of hexanes $(7 \times 20 \mathrm{~mL})$ for extraction, a dark red emulsion formed and the hexanes layer was carefully decanted, making sure to keep the emulsion in the separatory funnel for subsequent extractions. The combined organic layers were washed with $\mathrm{H}_{2} \mathrm{O}(2 \times 50 \mathrm{~mL})$ and dried with $\mathrm{MgSO}_{4}$ before filtering through a pad of Celite on a 
fritted funnel to yield a clear, lightly colored solution. The solvent was then removed under reduced pressure to yield an off-white/orange crude solid. The crude product was subjected to purification by column chromatography with 1:1 DCM:Hexanes with 1\% TFA as eluent to yield a white solid that was further purified via sequential sublimation $\left(50{ }^{\circ} \mathrm{C}, 0.1\right.$ torr to remove residual TFA for 1 hour, then $75{ }^{\circ} \mathrm{C}, 0.1$ torr to sublime the desired product).

Yield: $580 \mathrm{mg}(43 \%)$, white solid

${ }^{1} \mathbf{H}$ NMR (400 MHz, $\left.\mathbf{C}_{6} \mathbf{D}_{\mathbf{6}}\right)$ : $\delta$ 3.5-1.4 (m, 9H, B $\left.\mathrm{B}_{\text {carborane }}-\mathrm{H}\right), 2.01$ (s, 2H, $\left.\mathrm{C}_{\text {carborane }}-\mathrm{H}\right), 1.06$ (s, $12 \mathrm{H})$

${ }^{13} \mathbf{C}\left\{{ }^{1} \mathbf{H}\right\}$ NMR (100 MHz, $\left.\mathbf{C}_{6} \mathbf{D}_{6}\right): \delta 82.61,56.75,24.76$

${ }^{11}$ B NMR (128 MHz): $\delta 35.26(\mathrm{~s}, 1 \mathrm{~b}),-5.74\left(\mathrm{~d}, 2 \mathrm{~B},{ }^{1} J_{B H}=163 \mathrm{~Hz}\right),-8.88\left(\mathrm{~d}, 1 \mathrm{~B},{ }^{1} J_{B H}=\right.$ $154 \mathrm{~Hz}),-10.73(\mathrm{~s}, 1 \mathrm{~B}),-12.28\left(\mathrm{~d}, 4 \mathrm{~B},{ }^{1} J_{B H}=166 \mathrm{~Hz}\right),-15.53(\mathrm{~d}, 1 \mathrm{~B}),-16.19(\mathrm{~d}, 1 \mathrm{~B})$

HRGC-MS $m / z: 270.2765$ (calc. 270.1800)

Elemental Analysis Calculated for $\mathrm{C}_{8} \mathrm{~B}_{11} \mathrm{H}_{23} \mathrm{O}_{2}$ : C, 35.27; H, 8.52; found: $\mathrm{C}, 35.57 ; \mathrm{H}$, 8.77

\section{9-B(OCMe $\left.2 \mathrm{CMe}_{2} \mathrm{O}\right)$-1,2-dicarba-closo-dodecaborane (2b, 1 mmol scale)}

$\mathrm{B}_{2} \mathrm{pin}_{2}$ (400 mg, $\left.1.5 \mathrm{mmol}, 1.5 \mathrm{eq}\right)$ and $\mathrm{CsOH} \cdot \mathrm{H}_{2} \mathrm{O}(252 \mathrm{mg}, 1.5 \mathrm{mmol}, 1.5 \mathrm{eq})$ were added to an oven-dried reaction tube equipped with a PTFE septum cap and evacuated and backfilled with $\mathrm{N}_{2}$ three times. Then, DMF $(1.88 \mathrm{~mL})$ was added and the resulting solution was allowed to stir at room temperature for five minutes before the addition of 9-I-ortho$\mathrm{C}_{2} \mathrm{~B}_{10} \mathrm{H}_{12}(270 \mathrm{mg}, 1 \mathrm{mmol})$ and dppf-Pd-G3 precatalyst $(45 \mathrm{mg}, 5 \mathrm{~mol} \%)$ under positive $\mathrm{N}_{2}$ pressure. The reaction was allowed to stir at room temperature for $6 \mathrm{~h}$. After $6 \mathrm{~h}$, the reaction was quenched by the addition of distilled $\mathrm{H}_{2} \mathrm{O}(20 \mathrm{~mL})$ to yield a cloudy/tan solution. The quenched reaction mixture was subsequently extracted with hexanes $(5 \times 10$ $\mathrm{mL})$ and the combined organic layers were washed with $\mathrm{H}_{2} \mathrm{O}(2 \times 25 \mathrm{~mL})$ and dried with $\mathrm{MgSO}_{4}$ before filtering through a pad of Celite on a fritted funnel to yield a clear, lightly colored solution. The solvent was then removed under reduced pressure to yield an offwhite/orange crude solid. The crude product was subjected to purification by column chromatography with 1:1 DCM:Hexanes with 1\% TFA as eluent to yield a white solid that was further purified via sequential sublimation $\left(50^{\circ} \mathrm{C}, 0.1\right.$ torr to remove residual TFA for 1 hour, then $85^{\circ} \mathrm{C}, 0.1$ torr to sublime the desired product).

Yield: $114 \mathrm{mg}(42 \%)$, white solid

${ }^{1} \mathbf{H}$ NMR (400 MHz, $\left.\mathbf{C}_{6} \mathbf{D}_{\mathbf{6}}\right)$ : $\delta$ 3.7-1.4 (m, 9H, $\left.\mathrm{B}_{\text {carborane }}-\mathrm{H}\right), 2.09$ (s, 1H, $\left.\mathrm{C}_{\text {carborane }}-\mathrm{H}\right), 2.03$ (s, $\left.1 \mathrm{H}, \mathrm{C}_{\text {carborane }} \mathrm{H}\right), 1.03(\mathrm{~s}, 12 \mathrm{H})$

${ }^{13} \mathbf{C}\left\{{ }^{1} \mathbf{H}\right\}$ NMR (100 MHz, $\left.\mathbf{C}_{6} \mathbf{D}_{\mathbf{6}}\right): \delta 82.40,57.00,55.79,24.74$

${ }^{11}$ B NMR (128 MHz): $\delta 34.53$ (s, 1B), $-1.68\left(\mathrm{~d}, 1 \mathrm{~B},{ }^{1} J_{B H}=145 \mathrm{~Hz}\right),-2.82(\mathrm{~s}, 1 \mathrm{~B}),-8.44$ $\left(\mathrm{d}, 2 \mathrm{~B},{ }^{1} J_{B H}=148 \mathrm{~Hz}\right),-13.31\left(\mathrm{~d}, 4 \mathrm{~B},{ }^{1} J_{B H}=172 \mathrm{~Hz}\right),-14.64\left(\mathrm{~d}, 2 \mathrm{~B},{ }^{1} J_{B H}=175 \mathrm{~Hz}\right)$

HRGC-MS $m / z: 270.2796$ (calc. 270.1800) 


\section{Reactions with $2 a, 2 b$, and 3-Bpin-oCB}

\section{Synthesis of 9-BF3K-1,7-dicarba-closo-dodecaborane (3a)}

Synthetic procedures adapted from reference 4. 9-Bpin-mCB $(675 \mathrm{mg}, 2.5 \mathrm{mmol})$ was added to a round-bottomed flask equipped with a stir bar and suspended in a methanol and acetonitrile mixture $(1: 1,25.0 \mathrm{~mL})$. While stirring the dissolved boronic ester, a solution of potassium fluoride in $\mathrm{H}_{2} \mathrm{O}(1.19 \mathrm{~g}$ in $6.25 \mathrm{~mL})$ was added dropwise over 5 minutes while heating at $45^{\circ} \mathrm{C}$. Once addition was complete, the reaction was stirred for an additional 25 minutes at $45{ }^{\circ} \mathrm{C}$. Subsequently, a solution of L-(+)-tartaric acid in a minimal amount of THF $(1.58 \mathrm{~g}$ in $\sim 10 \mathrm{~mL}$, sonication and heat may be required to fully dissolve the acid) was added dropwise over 10 minutes to the stirring mixture at $45{ }^{\circ} \mathrm{C}$ as a white precipitate formed. The reaction was stirred for an additional $20 \mathrm{~min}$ at $45^{\circ} \mathrm{C}$ before the slow addition of two acetonitrile portions $(2 \times 15 \mathrm{~mL})$ over a $10 \mathrm{~min}$ period before removing from heat. The precipitate was filtered off and washed with acetonitrile. The filtrate was then concentrated under reduced pressure to yield a white, crystalline powder. Remaining 2a and pinacol were removed by heating with a heat gun under high vacuum until pinacol no longer condensed inside the flask, yielding $\mathbf{3 a}$ as a fine, white powder.

Yield: $510 \mathrm{mg}(82 \%)$, white solid

${ }^{1} \mathrm{H}$ NMR (500 MHz, CD $\left.{ }_{3} \mathbf{C N}\right): \delta 3.10\left(\mathrm{~s}, 2 \mathrm{H}, \mathrm{C}_{\text {carborane }}-\mathrm{H}\right), 2.8-1.3\left(\mathrm{~m}, 9 \mathrm{H}, \mathrm{B}_{\text {carborane }}-\mathrm{H}\right)$ ${ }^{13} \mathbf{C}\left\{{ }^{1} \mathrm{H}\right\}$ NMR (100 MHz, $\left.\mathbf{C D}_{3} \mathrm{CN}\right): \delta 57.15$

${ }^{11}$ B NMR (160 MHz): $\delta 4.74$ (s, 1B), -2.49 (s, 1B), $-5.54\left(\mathrm{~d}, 2 \mathrm{~B},{ }^{1} J_{B H}=161 \mathrm{~Hz}\right),-8.96(\mathrm{~d}$, $\left.1 \mathrm{~B},{ }^{1} J_{B H}=146 \mathrm{~Hz}\right),-11.79\left(\mathrm{~d}, 2 \mathrm{~B},{ }^{1} J_{B H}=158 \mathrm{~Hz}\right),-12.34\left(\mathrm{~d}, 2 \mathrm{~B},{ }^{1} J_{B H}=158 \mathrm{~Hz}\right),-15.52$ $\left(\mathrm{d}, 1 \mathrm{~B},{ }^{1} J_{B H}=174 \mathrm{~Hz}\right),-16.64\left(\mathrm{~d}, 1 \mathrm{~B},{ }^{1} J_{B H}=170 \mathrm{~Hz}\right)$

${ }^{19}$ F NMR (376 MHz): $\delta-127.07$ (s, br)

DART-MS $m / z: 211.1916$ (calc. 211.1903)

\section{Synthesis of 9-B(OH)2-1,7-dicarba-closo-dodecaborane (4a)}

Synthetic procedures adapted from reference 5. 9-Bpin-mCB $(135 \mathrm{mg}, 0.5 \mathrm{mmol})$ was added to a screw-top reaction tube equipped with a stir bar and dissolved in EtOH (1.7 mL) and conc. $\mathrm{HCl}(3.4 \mathrm{~mL})$. The resulting solution was stirred at room temperature for 10 minutes before refluxing the solution $\left(\sim 80^{\circ} \mathrm{C}\right)$ for $8 \mathrm{~h}$. After $8 \mathrm{~h}$, the reaction mixture was allowed to cool to room temperature and was extracted with $\mathrm{Et}_{2} \mathrm{O}(3 \times 10 \mathrm{~mL})$. The organic layers were combined and the solvent was subsequently removed under reduced pressure to yield a light grey oil that solidifies into an off-white solid.

Yield: $79 \mathrm{mg}(83 \%)$, off-white solid

${ }^{1}$ H NMR (400 MHz, DMSO-d 6 ): $\delta 7.27$ (s, 2H), 3.85 (s, 2H, C carborane-H) , 3.1-1.3 (m, 9H, $\left.\mathrm{B}_{\text {carborane- }} \mathrm{H}\right)$

${ }^{13} \mathrm{C}\left\{{ }^{1} \mathrm{H}\right\}$ NMR (100 MHz, DMSO-d6): $\delta 58.33$

${ }^{11}$ B NMR (128 MHz): $\delta 33.88$ (s, 1B), -11.11 (m, 10B)

DART-MS $m / z: 187.1943$ (calc. 187.1934) 


\section{Synthesis of 9-B(OH)2-1,2-dicarba-closo-dodecaborane (4b)}

Prepared in an analogous method to $\mathbf{4 a}$, where instead $\mathbf{2 b}$ was used.

Yield: $50 \mathrm{mg}(53 \%)$, off-white solid

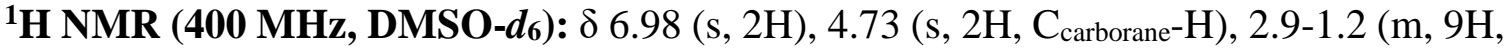
B $_{\text {carborane }}-\mathrm{H}$ )

${ }^{13} \mathbf{C}\left\{{ }^{1} \mathrm{H}\right\}$ NMR (100 MHz, DMSO-d $\left.\mathbf{6}\right): \delta 58.91,58.38$

${ }^{11}$ B NMR (128 MHz): $\delta 34.35$ (s, 1B), -1.64 (m, 2B), -7.84 (d, 2B, $\left.{ }^{1} J_{B H}=150 \mathrm{~Hz}\right),-12.29$ $(\mathrm{m}, 6 \mathrm{~B})$

DART-MS $m / z: 187.1938$ (calc. 187.1934)

\section{Synthesis of 3-B(OH)2-1,2-dicarba-closo-dodecaborane (4c)}

Prepared in an analogous method to $4 \mathbf{a}$, where instead 3-Bpin-oCB (prepared according to reference 6) was used.

Yield: $78 \mathrm{mg}(83 \%)$, off-white solid

${ }^{1}$ H NMR (400 MHz, DMSO-d $\left.\mathbf{6}\right): \delta 5.00$ (s, br, 2H), 4.57 (s, 2H, $\mathrm{C}_{\text {carborane-H) }}$ ) 2.8-1.2 (m, $\left.9 \mathrm{H}, \mathrm{B}_{\text {carborane }}-\mathrm{H}\right)$

${ }^{13} \mathbf{C}\left\{{ }^{1} \mathrm{H}\right\}$ NMR (100 MHz, DMSO-d $): \delta 58.17$

${ }^{11}$ B NMR (128 MHz): $\delta 32.16$ (s, 1B), $-2.78\left(\mathrm{~d}, 2 \mathrm{~B},{ }^{1} J_{B H}=135 \mathrm{~Hz}\right),-12.07(\mathrm{~m}, 8 \mathrm{~B})$

DART-MS $m / z: 187.1937$ (calc. 187.1934)

\section{Cyclic Voltammetry of $3 a$}

Cyclic voltammetry measurements of 3a $(2 \mathrm{mM})$ were performed with a Gamry Instruments Interface $1010 \mathrm{E}$ potentiostat using a glassy carbon working electrode, platinum wire counter electrode and $\mathrm{Ag} / \mathrm{Ag}^{+}$pseudo-reference electrode wire. Measurements were conducted at a scan rate of $100 \mathrm{mV} / \mathrm{s}$ with $\left[\mathrm{TBA}^{\mathrm{T}}\left[\mathrm{PF}_{6}\right](0.15 \mathrm{M})\right.$ supporting electrolyte under an inert atmosphere of $\mathrm{N}_{2}$ in dry acetonitrile, and referenced vs. $\mathrm{Fc} / \mathrm{Fc}^{+}$.

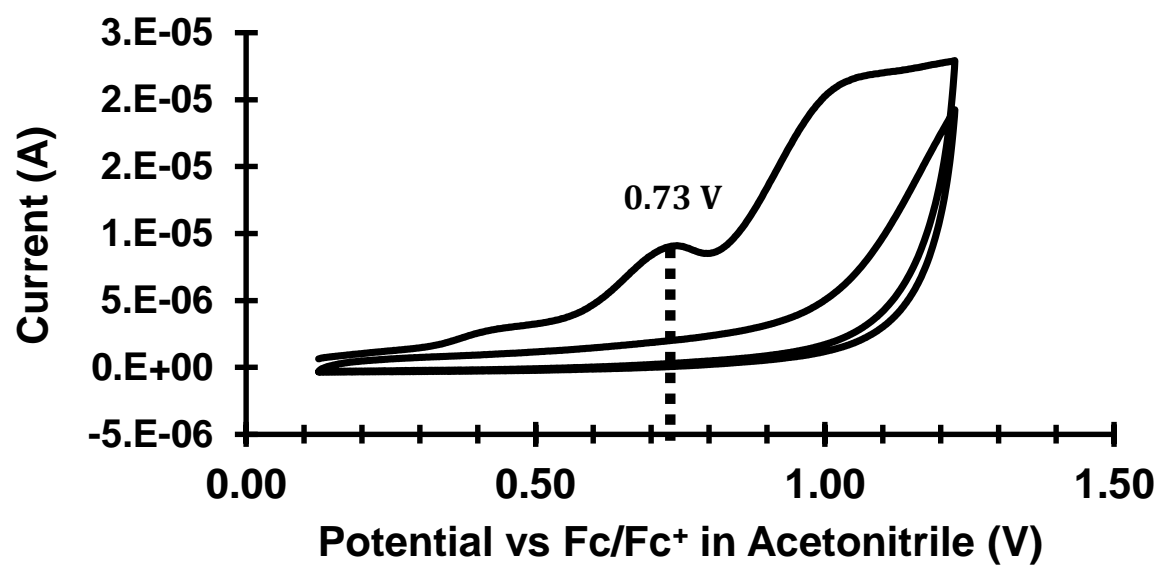




\section{Optimization of Oxidation Protocol with N-Heterocycles}

Optimizations were used to identify a suitable excess of trifluoroborate salt (3a) and manganese(III) acetate dihydrate $\left(\mathrm{Mn}(\mathrm{OAc})_{3} \cdot 2 \mathrm{H}_{2} \mathrm{O}\right)$, solvent type and amount $(\mathbf{S})$ required to achieve optimal conversion to (4-methylquinoline)-mCB. Manganese(III) acetate used in Entry 6 was dried under high vacuum for $4 \mathrm{~h}$ at $150{ }^{\circ} \mathrm{C}$. 3a was added to reaction tube and dissolved in solvent. Once dissolved, 4-methylquinoline $(0.05 \mathrm{mmol}, 1 \mathrm{eq})$ and TFA (1 eq) were added to the solution. After stirring the reaction mixture for two minutes at room temperature, $\mathrm{Mn}(\mathrm{OAc})_{3} \cdot 2 \mathrm{H}_{2} \mathrm{O}$ was added before the reaction tube was sealed with a PTFE septum cap. The reaction tube was then placed in a preheated oil bath at $60{ }^{\circ} \mathrm{C}$ and stirred for $18 \mathrm{~h}$ before removing from heat. All volatiles were removed by high vacuum before resuspending the crude reaction mixture in $\sim 1 \mathrm{~mL}$ of ethyl acetate and washing with $\sim 1 \mathrm{~mL}$ of aqueous sat. $\mathrm{NaHCO}_{3}$. An aliquot was taken from the organic layer and analyzed by HRGC-MS.

Table S6. Optimization of oxidation conditions for carboranyl radical-heterocycle coupling

\begin{tabular}{|c|c|c|c|c|}
\hline $\begin{array}{c}\text { Entry } \\
\#\end{array}$ & \multicolumn{3}{|c|}{ Experimental Conditions } & \% conversion by HRGC-MS \\
\hline $\mathbf{1}$ & $\mathbf{3 a}$ & $\mathbf{M n}(\mathbf{O A c})_{\mathbf{3}} \cdot \mathbf{2} \mathbf{H}_{\mathbf{2}} \mathbf{O}$ & Solvent & $\mathbf{5 f}$ \\
\hline $\mathbf{2}$ & $1.5 \mathrm{eq}$ & $3 \mathrm{eq}$ & $\mathrm{AcOH}, 1 \mathrm{~mL}$ & 17 \\
\hline $\mathbf{3}$ & $2 \mathrm{eq}$ & $4 \mathrm{eq}$ & $\mathrm{AcOH}, 1 \mathrm{~mL}$ & 28 \\
\hline $\mathbf{4}$ & $2 \mathrm{eq}$ & $4 \mathrm{eq}$ & $\mathrm{AcOH}, 0.5 \mathrm{~mL}$ & 32 \\
\hline $\mathbf{5}$ & $2 \mathrm{eq}$ & $4 \mathrm{eq}$ & $1: 1 \mathrm{AcOH}: \mathrm{H}_{2} \mathrm{O}, 0.5 \mathrm{~mL}$ & 10 \\
\hline $\mathbf{6}$ & $2 \mathrm{eq}$ & $4 \mathrm{eq}$ & $\mathrm{AcOH}, 0.25 \mathrm{~mL}$ & 32 \\
\hline
\end{tabular}

\section{HRGC-MS for Entry 1}

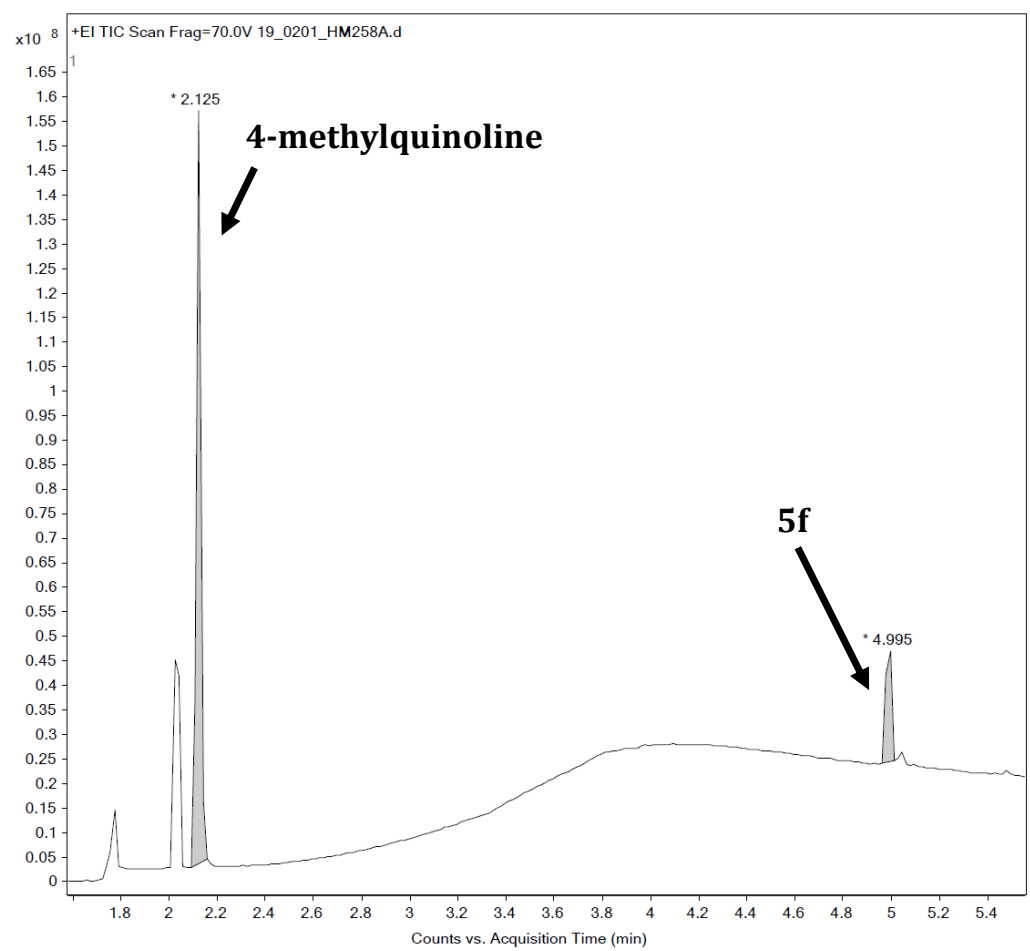




\section{HRGC-MS for Entry 3}

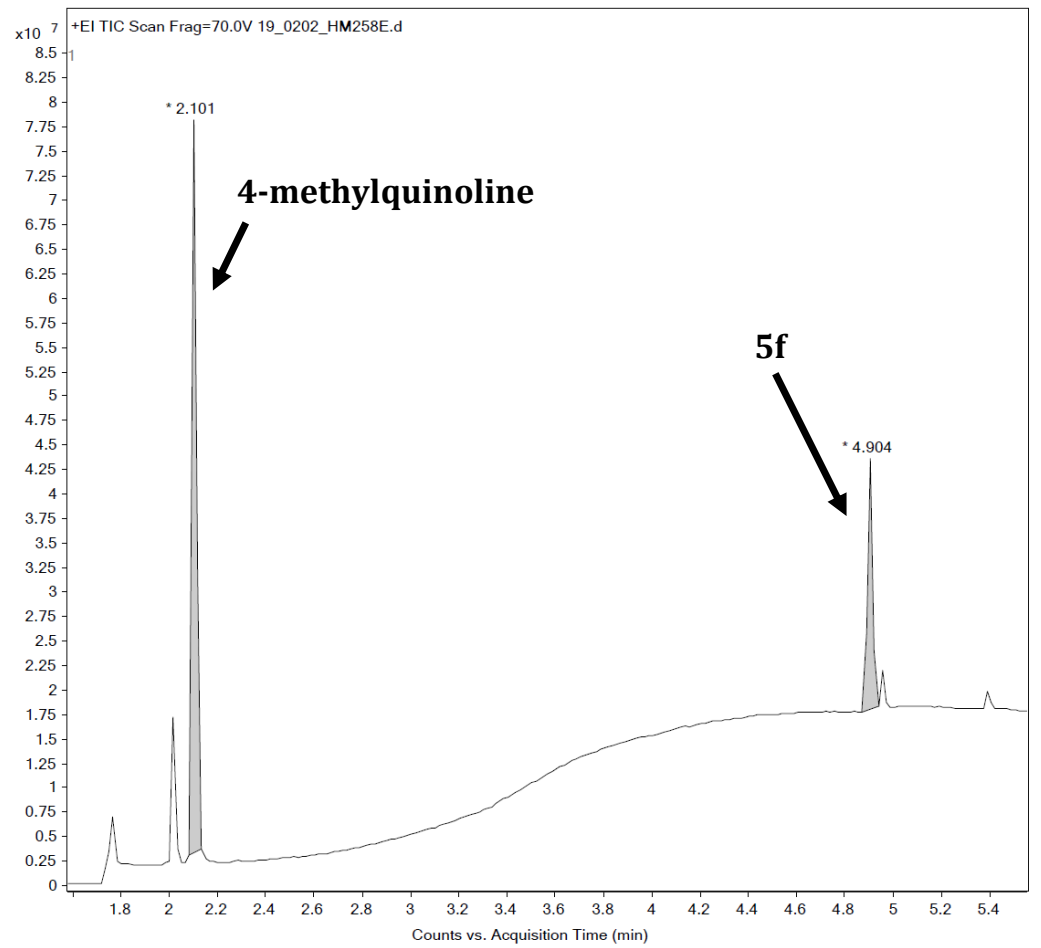

\section{Inhibition by 9,10-Dihydroanthracene}

Radical inhibition experiments were used to confirm the need for a radical intermediate in the oxidation of 3a and subsequent trapping by 4-methylquinoline. Three trials were prepared where $3 \mathbf{a}(25 \mathrm{mg}, 0.1 \mathrm{mmol}, 2 \mathrm{eq})$ and 4-methylquinoline $(6.6 \mu \mathrm{L}, 0.05 \mathrm{mmol}, 1$ eq) were added to a reaction tube and dissolved in distilled acetic acid $(0.4 \mathrm{~mL})$. Subsequently, trifluoroacetic acid (5 $\mu \mathrm{L}, 1.25 \mathrm{eq})$, 9,10-dihydroanthracene, and manganese(III) acetate dihydrate (54 mg, $0.2 \mathrm{mmol}, 4 \mathrm{eq})$ were added to the stirring solution. The reaction was sealed with a PTFE cap and the reaction mixture was stirred for $18 \mathrm{~h}$ at $60^{\circ} \mathrm{C}$. After $18 \mathrm{~h}$ the reaction was then allowed to cool to room temperature and the solvent was removed under reduced pressure. The crude residue was re-suspended in EtOAc $(1 \mathrm{~mL})$ and washed with an aqueous solution of sat. $\mathrm{NaHCO}_{3}(1 \mathrm{~mL})$. An aliquot of the organic layer was subsequently taken for analysis by HRGC-MS.

Table S7. Inhibition by 9,10 -Dihydroanthracene

\begin{tabular}{|c|c|c|}
\hline $\begin{array}{c}\text { Entry } \\
\#\end{array}$ & Experimental Conditions & $\begin{array}{c}\text { \% inhibition of 5f } \\
\text { by HRGC-MS }\end{array}$ \\
\hline $\mathbf{1}$ & $\mathbf{9 , 1 0 - d i h y d r o a n t h r a c e n e}$ & $0 \%$ \\
\hline $\mathbf{2}$ & ----- & $68 \%$ \\
\hline $\mathbf{3}$ & $0.5 \mathrm{eq}$ & $71 \%$ \\
\hline
\end{tabular}




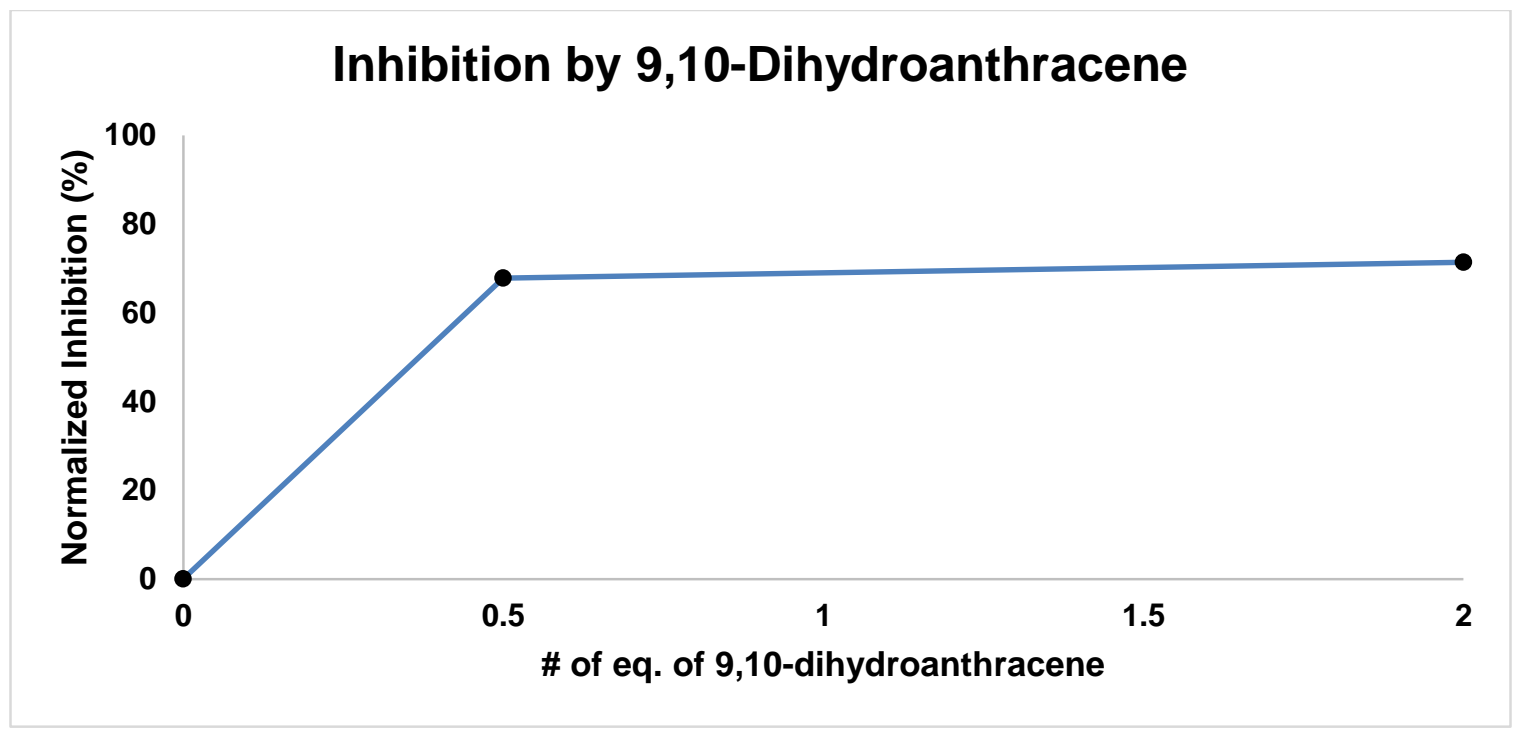

\section{NMR and GC-MS Experiments for Reactions with Electron-Poor and Sterically Blocked N-Heterocycles}

NMR and GC-MS experiments were used to further validate the anticipated regioselectivity of N-heterocycle substitution when using electron-poor N-heterocycles (4triflouoromethylpyridine) or when some positions on the N-heterocycle are sterically blocked (3,5-dimethylpyridine, 2,4,6-trimethylpyridine). These reactions were prepared where $3 \mathbf{a}(25 \mathrm{mg}, 0.1 \mathrm{mmol}, 2 \mathrm{eq})$ and substrate $(0.05 \mathrm{mmol}, 1 \mathrm{eq})$ of interest were added to a reaction tube and dissolved in distilled acetic acid $(0.4 \mathrm{~mL})$ and TFA $(5 \mu \mathrm{L}, 1.25 \mathrm{eq})$ was added. Once all of the solids had dissolved, manganese(III) acetate dihydrate $(54 \mathrm{mg}$, $0.2 \mathrm{mmol}, 4 \mathrm{eq}$ ) was added to the stirring solution. The reactions were then sealed with a PTFE cap and the reaction mixture was stirred for $18 \mathrm{~h}$ at $60{ }^{\circ} \mathrm{C}$. After $18 \mathrm{~h}$ the reaction was then allowed to cool to room temperature and EtOAc $(1 \mathrm{~mL})$ was added, followed by the addition of an aqueous solution of sat. $\mathrm{NaHCO}_{3}(\sim 4 \mathrm{~mL})$ to neutralize the mixture. The organic layer was removed, and the aqueous layer was further extracted with EtOAc $(2 \mathrm{x}$ $2 \mathrm{~mL}$ ). An aliquot of the combined organic layers was subsequently taken for analysis by HRGC-MS. The remaining EtOAc was removed under reduced pressure and the crude residue was redissolved in dichloromethane- $d_{6}$ for analysis by NMR spectroscopy. See reference 7 for further analysis of carbon-based radical-heterocycle coupling regioselectivity. 
Reaction with 4-trifuoromethylpyridine

HRGC-MS of Crude Reaction Mixture

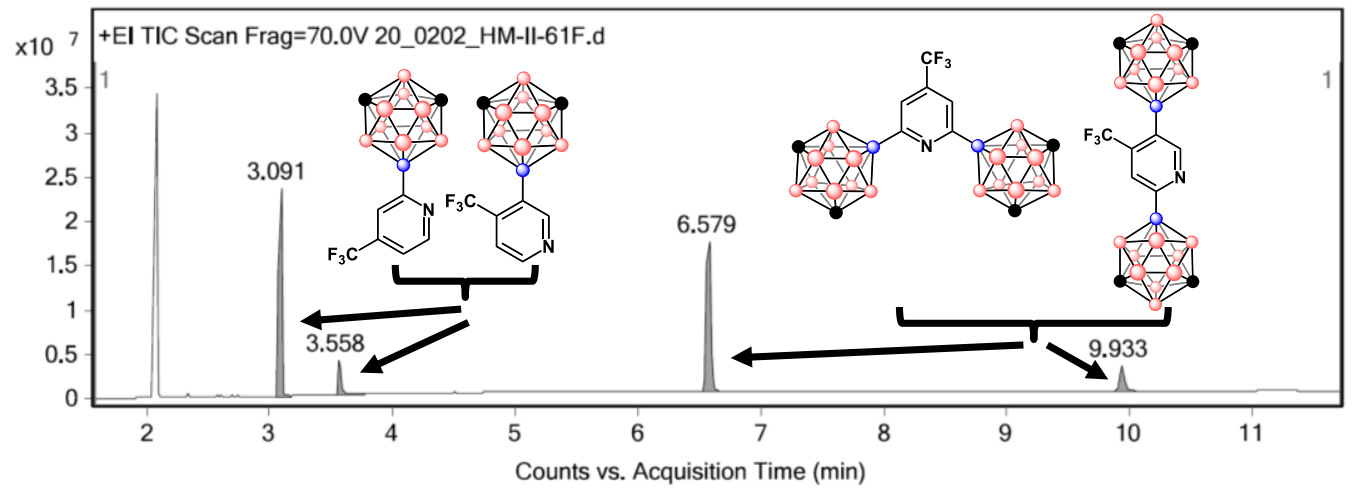

${ }^{1} \mathrm{H}$ NMR $\left({ }^{19} \mathrm{~F}\right.$ NMR inlay) of Crude Reaction Mixture (10-6.5 ppm)

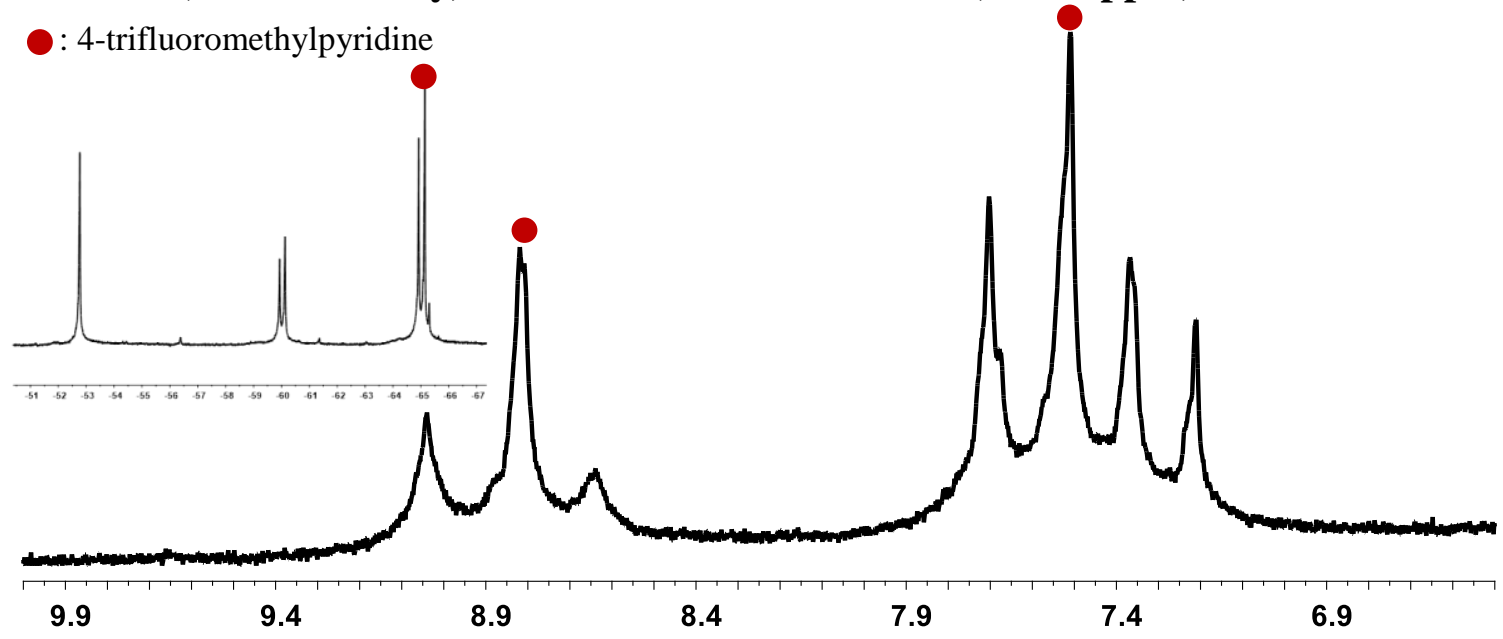

Reaction with 3,5-dimethylpyridine

HRGC-MS of Crude Reaction Mixture

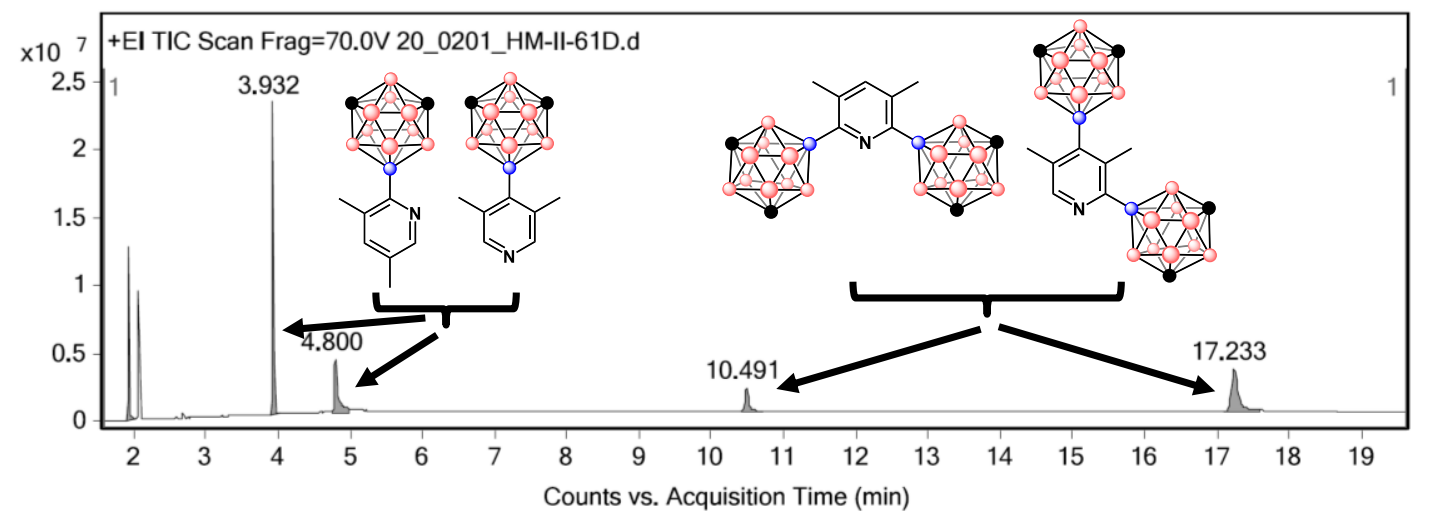


${ }^{1} \mathrm{H}$ NMR of Crude Reaction Mixture (10-6.5 ppm)

: 3,5-dimethylpyridine

: impurity present in 3,5dimethylpyridine

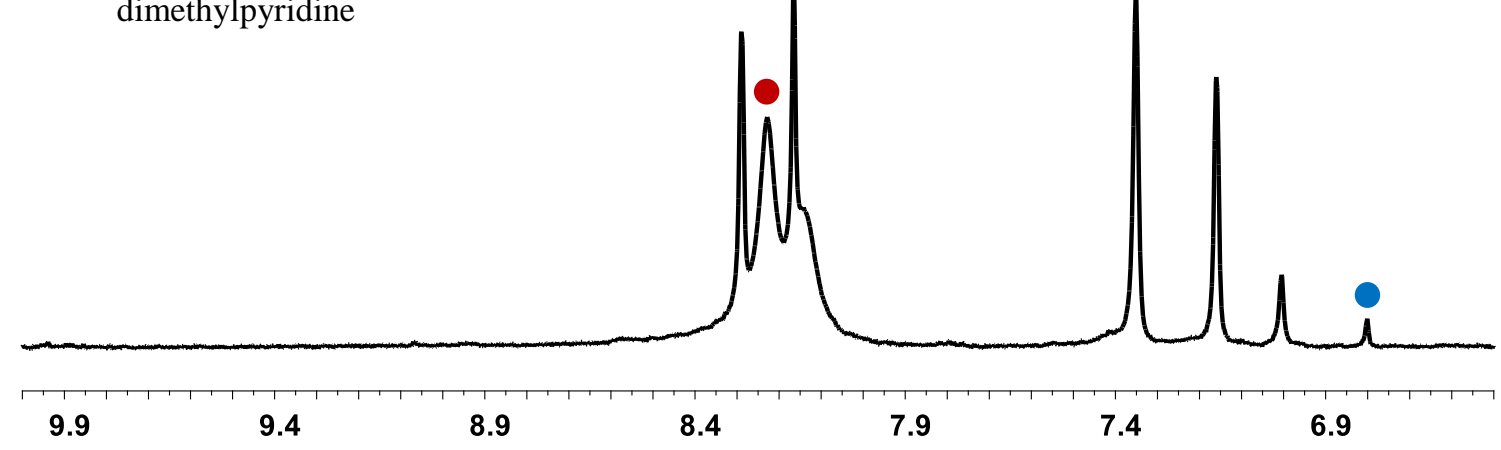

\section{Reaction with 2,4,6-trimethylpyridine}

\section{HRGC-MS of Crude Reaction Mixture}

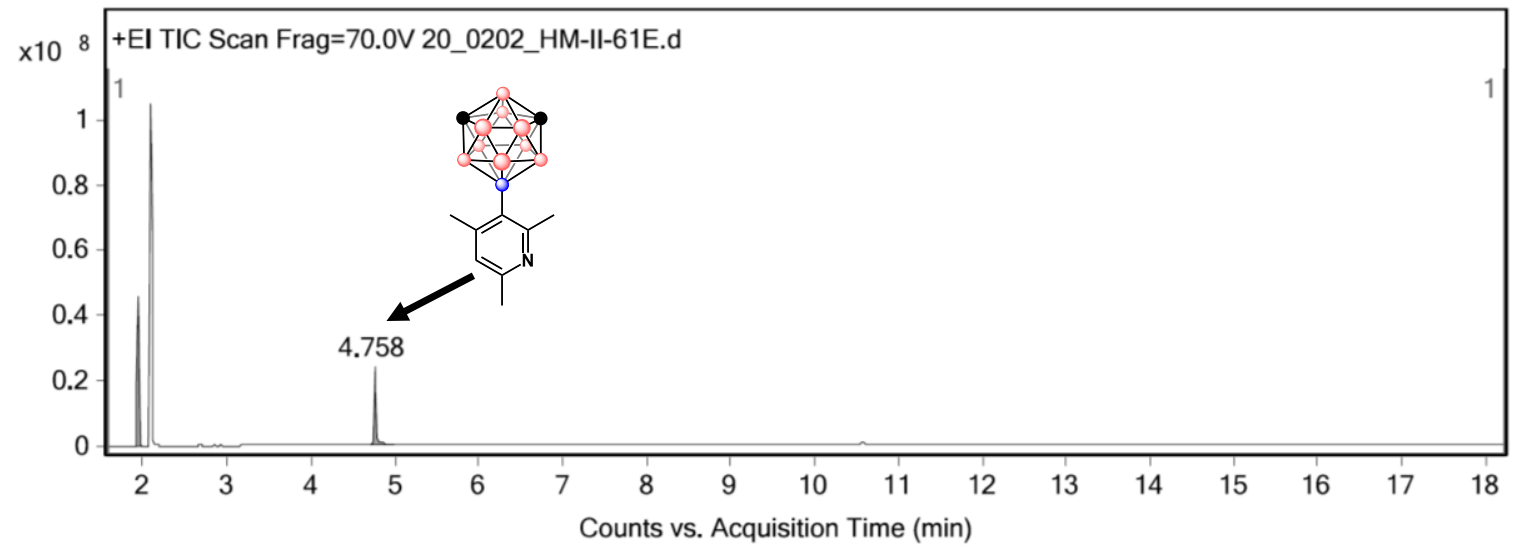

${ }^{1} \mathrm{H}$ NMR of Crude Reaction Mixture (10-6.5 ppm)

๑: 2,4,6-trimethylpyridine

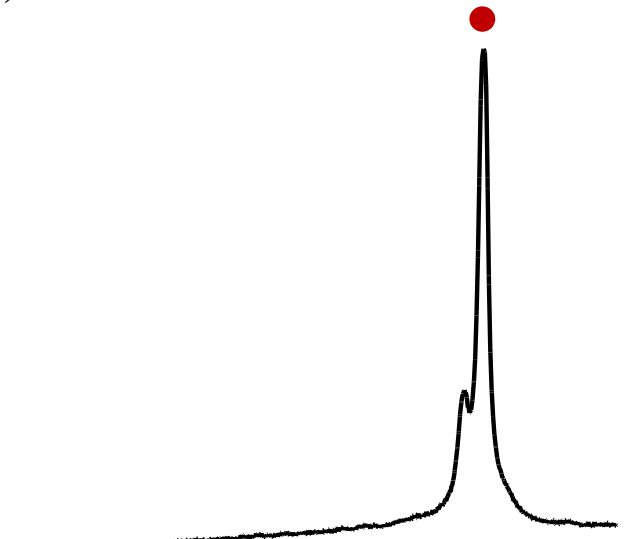

\begin{tabular}{llllllll}
\hline & 9.9 & 9.4 & 8.9 & 8.4 & 7.9 & 7.4 & 6.9
\end{tabular}




\section{General Procedures for Oxidation of 3a}

\section{General Procedure A}

3a $(125 \mathrm{mg}, 0.5 \mathrm{mmol}, 2 \mathrm{eq})$ and the substrate $(0.25 \mathrm{mmol}, 1 \mathrm{eq})$ of interest were added to a reaction tube and dissolved in distilled acetic acid $(2 \mathrm{~mL})$. Subsequently, manganese(III) acetate dihydrate $(270 \mathrm{mg}, 1 \mathrm{mmol}, 4 \mathrm{eq})$ was added to the stirring solution. The reaction tube was sealed with a PTFE cap and the reaction mixture was stirred for $18 \mathrm{~h}$ at $60{ }^{\circ} \mathrm{C}$. After $18 \mathrm{~h}$ the reaction was then allowed to cool to room temperature and the solvent was removed under reduced pressure. The crude residue was re-suspended in EtOAc $(2 \mathrm{~mL})$ and washed with an aqueous solution of sat. $\mathrm{NaHCO}_{3}(2 \mathrm{~mL})$. The organic layer was separated from aqueous layer before subsequent extractions with EtOAc $(3 \times 2 \mathrm{~mL})$. The combined organic layers were dried under reduced pressure to yield the crude product that was further purified by column chromatography. All compounds subjected to purification by column chromatography were dry loaded with silica onto the column.

\section{General Procedure B}

3a (125 mg, $0.5 \mathrm{mmol}, 2 \mathrm{eq})$ and the substrate $(0.25 \mathrm{mmol}, 1 \mathrm{eq})$ of interest were added to a reaction and dissolved in distilled acetic acid $(2 \mathrm{~mL})$. Subsequently, trifluoroacetic acid ( $25 \mu \mathrm{L}, 1.25 \mathrm{eq}$ ) and manganese(III) acetate dihydrate (270 mg, $1 \mathrm{mmol}, 4 \mathrm{eq}$ ) were added to the stirring solution. The reaction tube was sealed with a PTFE cap and the reaction mixture was stirred for $18 \mathrm{~h}$ at $60{ }^{\circ} \mathrm{C}$. The reaction was then allowed to cool to room temperature and the solvent was removed under reduced pressure. The crude residue was re-suspended in EtOAc $(2 \mathrm{~mL})$ and washed with an aqueous solution of sat. $\mathrm{NaHCO}_{3}(2$ $\mathrm{mL}$ ). The organic layer was separated from aqueous layer before subsequent extractions with EtOAc $(3 \times 2 \mathrm{~mL})$. The combined organic layers were dried under reduced pressure to yield the crude product that was further purified by column chromatography. All compounds subjected to purification by column chromatography were dry loaded with silica onto the column.

\section{9-O-(2,2,6,6-tetramethylpiperidin-1-yl)oxyl-1,7-dicarba-closo-dodecaborane (5a)}

Procedure A, though 3a $(93.75 \mathrm{mg}, 0.375 \mathrm{mmol}, 1.5 \mathrm{eq})$ and manganese(III) acetate dihydrate (101.25 mg, $0.375 \mathrm{mmol}, 1.5 \mathrm{eq}$ ) was used instead

Isolation: Flash column chromatography, 1:9 Ethyl Acetate:Hexanes

Yield: $55 \mathrm{mg}$ (74\%), light orange solid

${ }^{1}$ H NMR (400 MHz, CDCl3): $\delta$ 3.30-1.25 (m, 9H, B carborane-H), 2.65 (s, 2H, C carborane-H), $1.45(\mathrm{~s}, 6 \mathrm{H}), 1.19(\mathrm{~m}, 12 \mathrm{H})$

${ }^{13} \mathbf{C}\left\{{ }^{1} \mathbf{H}\right\}$ NMR (100 MHz, CDCl 3$): \delta$ 60.79, 48.85, 40.20, 35.00, 19.93, 17.14

${ }^{11}$ B NMR (128 MHz): $\delta 10.54(\mathrm{~s}, 1 \mathrm{~B}),-8.58\left(\mathrm{~d}, 2 \mathrm{~B},{ }^{1} J_{B H}=157 \mathrm{~Hz}\right),-11.96\left(\mathrm{~d}, 1 \mathrm{~B},{ }^{1} J_{B H}=\right.$ $146 \mathrm{~Hz}),-15.32\left(\mathrm{~d}, 2 \mathrm{~B},{ }^{1} J_{B H}=169 \mathrm{~Hz}\right),-17.37\left(\mathrm{~d}, 2 \mathrm{~B},{ }^{1} J_{B H}=169 \mathrm{~Hz}\right),-20.86\left(\mathrm{~d}, 1 \mathrm{~B},{ }^{1} J_{B H}\right.$ $=185 \mathrm{~Hz}),-26.41\left(\mathrm{~d}, 1 \mathrm{~B},{ }^{1} J_{B H}=182 \mathrm{~Hz}\right)$

HRGC-MS $m / z: 299.3244$ (calc. 299.3252) 


\section{9-S-phenylsulfide-1,7-dicarba-closo-dodecaborane (5b)}

Procedure A

Isolation: Flash column chromatography, 1:99 Ethyl Acetate:Hexanes

Yield: $70 \mathrm{mg}(56 \%)$, white solid

${ }^{1}$ H NMR (400 MHz, CDCl3): $\delta 7.52$ (m, 2H), 7.26 (m, 3H), 3.40-1.40 (m, 9H, B carborane$\mathrm{H}), 2.91$ (s, 2H, $\mathrm{C}_{\text {carborane-H) }}$

${ }^{13} \mathbf{C}\left\{{ }^{1} \mathbf{H}\right\}$ NMR (100 MHz, CDCl 3$): \delta 135.06,128.73,127.13,54.05$

${ }^{11}$ B NMR (128 MHz): $\delta 0.38(\mathrm{~s}, 1 \mathrm{~B}),-6.86\left(\mathrm{~d}, 2 \mathrm{~B},{ }^{1} J_{B H}=164 \mathrm{~Hz}\right),-10.05\left(\mathrm{~d}, 1 \mathrm{~B},{ }^{1} J_{B H}=\right.$ $154 \mathrm{~Hz}),-13.48\left(\mathrm{~d}, 2 \mathrm{~B},{ }^{1} J_{B H}=152 \mathrm{~Hz}\right),-14.34\left(\mathrm{~d}, 2 \mathrm{~B},{ }^{1} J_{B H}=154 \mathrm{~Hz}\right),-17.96\left(\mathrm{~d}, 1 \mathrm{~B},{ }^{1} J_{B H}\right.$ $=180 \mathrm{~Hz}),-20.89\left(\mathrm{~d}, 1 \mathrm{~B},{ }^{1} J_{B H}=185 \mathrm{~Hz}\right)$

HRGC-MS $m / z: 252.1957$ (calc. 252.1976)

\section{9-Se-phenylselenide-1,7-dicarba-closo-dodecaborane (5c)}

Procedure A

Isolation: Flash column chromatography, Hexanes to 1:99 Ethyl Acetate:Hexanes gradient Yield: $85 \mathrm{mg}$ (57\%), white solid

${ }^{1}$ H NMR (400 MHz, CDCl3): $\delta 7.63\left(\mathrm{~d}, 2 \mathrm{H},{ }^{1} \mathrm{~J}_{H H}=6.78 \mathrm{~Hz}\right), 7.24(\mathrm{~m}, 3 \mathrm{H}), 3.50-1.50(\mathrm{~m}$, 9H, B carborane-H), 2.95 (s, 2H, $\left.\mathrm{C}_{\text {carborane }}-\mathrm{H}\right)$

${ }^{13} \mathbf{C}\left\{{ }^{1} \mathbf{H}\right\}$ NMR (100 MHz, CDCl $\left.\mathbf{3}\right): \delta 136.37,129.00,128.76,127.20,55.17$

${ }^{11}$ B NMR (128 MHz): $\delta-4.09$ (s, 1B), $-6.39\left(\mathrm{~d}, 2 \mathrm{~B},{ }^{1} J_{B H}=170 \mathrm{~Hz}\right),-9.53\left(\mathrm{~d}, 1 \mathrm{~B},{ }^{1} J_{B H}=\right.$ $154 \mathrm{~Hz}),-13.02\left(\mathrm{~d}, 2 \mathrm{~B},{ }^{1} J_{B H}=159 \mathrm{~Hz}\right),-13.60\left(\mathrm{~d}, 2 \mathrm{~B},{ }^{1} J_{B H}=170 \mathrm{~Hz}\right),-17.28\left(\mathrm{~d}, 1 \mathrm{~B},{ }^{1} J_{B H}\right.$ $=180 \mathrm{~Hz}),-19.60\left(\mathrm{~d}, 1 \mathrm{~B},{ }^{1} J_{B H}=185 \mathrm{~Hz}\right)$

${ }^{77}$ Se NMR (95 MHz): $\delta 81.13\left(\mathrm{q},{ }^{1} J_{S e B}=45 \mathrm{~Hz}\right)$

HRGC-MS $m / z: 300.1881$ (calc. 300.1420)

\section{9-Te-phenyltelluride-1,7-dicarba-closo-dodecaborane (5d)}

Procedure A, though the reaction was performed under an inert atmosphere of argon.

Isolation: Flash column chromatography, Hexanes to 1:99 Ethyl Acetate:Hexanes gradient Yield: 46 mg (27\%), off-white solid

${ }^{1}$ H NMR (400 MHz, CDCl $): \delta 7.82\left(\mathrm{~d}, 2 \mathrm{H},{ }^{1} J_{H H}=7.78 \mathrm{~Hz}\right), 7.29\left(\mathrm{t}, 1 \mathrm{H},{ }^{1} J_{H H}=7.29 \mathrm{~Hz}\right)$, $7.14\left(\mathrm{t}, 1 \mathrm{H},{ }^{1} J_{H H}=8.10 \mathrm{~Hz}\right), 3.60-1.60\left(\mathrm{~m}, 9 \mathrm{H}, \mathrm{B}_{\text {carborane }}-\mathrm{H}\right), 3.01\left(\mathrm{~s}, 2 \mathrm{H}, \mathrm{C}_{\text {carborane }}-\mathrm{H}\right)$

${ }^{13} \mathbf{C}\left\{{ }^{1} \mathbf{H}\right\}$ NMR (100 MHz, CDCl 3$): \delta 140.81,128.80,127.46,108.71,57.00$

${ }^{11}$ B NMR (128 MHz): $\delta-5.78\left(\mathrm{~d}, 2 \mathrm{~B},{ }^{1} J_{B H}=175 \mathrm{~Hz}\right),-8.81\left(\mathrm{~d}, 1 \mathrm{~B},{ }^{1} J_{B H}=157 \mathrm{~Hz}\right),-12.64$ (m, 4B), -15.70 (s, 1B), -17.00 (m, 2B)

${ }^{125}$ Te NMR (158 MHz): $\delta 66.76$ (sept.)

HRGC-MS $m / z: 349.1301$ (calc. 349.1263) 


\section{9-Se-(9-seleno-1,2-dicarba-closo-dodecaborane)-1,7-dicarba-closo-dodecaborane (5e)}

Procedure A

Isolation: Flash column chromatography, Hexanes to 3:7 Ethyl Acetate:Hexanes gradient Yield: $53 \mathrm{mg},(29 \%)$, pale yellow solid

${ }^{1} \mathbf{H}$ NMR (400 MHz, $\mathbf{C D}_{2} \mathrm{Cl}_{2}$ ): $\delta 3.66$ (s, 1H, Cortho-carborane-H), 3.61 (s, 1H, Cortho-carborane$\mathrm{H}), 3.40-1.60\left(\mathrm{~m}, 18 \mathrm{H}, \mathrm{B}_{\text {carborane }} \mathrm{H}\right), 3.01\left(\mathrm{~s}, 2 \mathrm{H}, \mathrm{C}_{\text {meta-carborane }} \mathrm{H}\right)$

${ }^{13} \mathbf{C}\left\{{ }^{1} \mathbf{H}\right\}$ NMR (100 MHz, $\left.\mathbf{C D}_{\mathbf{2}} \mathbf{C l}_{2}\right): \delta 55.06,54.09,49.34$

${ }^{11}$ B NMR (128 MHz): $\delta 1.04$ (s, 1B), -2.36 (d, 2B), -6.60 (s, 1B), -6.62 (d, 2B), -8.90 (d, 2B), -10.05 (d, 1B), -14.45 (m, 9H), -17.98 (d, 1B), -20.41 (d, 1B)

${ }^{77}$ Se NMR (95 MHz): $\delta$-283.96 (m, br)

HRGC-MS $m / z: 366.2893$ (calc. 366.2893 )

\section{9-(2)-4-methylquinoline-1,7-dicarba-closo-dodecaborane (5f)}

Procedure B

Isolation: Flash column chromatography, 1:9 Ethyl Acetate:Hexanes

Yield: $22 \mathrm{mg}$ (30\%), white solid

${ }^{1} \mathbf{H}$ NMR $\left(400 \mathrm{MHz}, \mathbf{C D C l}_{3}\right): \delta 8.19\left(\mathrm{~d}, 1 \mathrm{H},{ }^{1} J_{H H}=8.05 \mathrm{~Hz}\right), 7.94\left(\mathrm{~d}, 1 \mathrm{H},{ }^{1} J_{H H}=8.62 \mathrm{~Hz}\right)$, $7.65\left(\mathrm{t}, 1 \mathrm{H},{ }^{1} J_{H H}=8.05 \mathrm{~Hz}\right), 3.60-1.80\left(\mathrm{~m}, 9 \mathrm{H}, \mathrm{B}_{\text {carborane }}-\mathrm{H}\right), 3.07\left(\mathrm{~s}, 2 \mathrm{H}, \mathrm{C}_{\text {carborane }}-\mathrm{H}\right), 2.67$ $(\mathrm{s}, 3 \mathrm{H})$

${ }^{13} \mathbf{C}\left\{{ }^{1} \mathbf{H}\right\}$ NMR (100 MHz, $\left.\mathbf{C D C l}_{3}\right): \delta 148.36,141.49,130.53,128.55,127.10,126.23$, $125.75,123.49,54.45,18.63$

${ }^{11}$ B NMR (128 MHz): $\delta-0.67$ (s, 1B), $-6.45\left(\mathrm{~d}, 2 \mathrm{~B},{ }^{1} J_{B H}=176 \mathrm{~Hz}\right),-9.71\left(\mathrm{~d}, 1 \mathrm{~B},{ }^{1} J_{B H}=\right.$ $159 \mathrm{~Hz}),-12.91\left(\mathrm{~d}, 2 \mathrm{~B},{ }^{1} J_{B H}=131 \mathrm{~Hz}\right),-13.82\left(\mathrm{~d}, 2 \mathrm{~B},{ }^{1} J_{B H}=154 \mathrm{~Hz}\right),-17.40\left(\mathrm{~d}, 1 \mathrm{~B},{ }^{1} J_{B H}\right.$ $=186 \mathrm{~Hz}),-19.27\left(\mathrm{~d}, 1 \mathrm{~B},{ }^{1} J_{B H}=235 \mathrm{~Hz}\right)$

HRGC-MS $m / z: 285.2964$ (calc. 285.2521)

Elemental Analysis Calculated for $\mathrm{C}_{12} \mathrm{~B}_{10} \mathrm{H}_{19} \mathrm{~N}$ : C, 50.15; H, 6.67; found: C, 50.18; H, 6.85

\section{9-(2)-benzothiazole-1,7-dicarba-closo-dodecaborane (5g)}

Procedure B, though the reaction was performed in 1:1 distilled acetic acid: $\mathrm{H}_{2} \mathrm{O}$ Isolation: Flash column chromatography, Hexanes to 2:8 Acetone:Hexanes gradient Yield: $28 \mathrm{mg}(40 \%)$, pale yellow solid

${ }^{1} \mathbf{H}$ NMR (400 MHz, $\left.\mathbf{C D C l}_{3}\right): \delta 8.15\left(\mathrm{dq}, 1 \mathrm{H},{ }^{1} J_{H H}=8.27 \mathrm{~Hz},{ }^{2} J_{H H}=0.88 \mathrm{~Hz}\right), 7.88(\mathrm{dq}$, $\left.1 \mathrm{H},{ }^{1} J_{H H}=7.97,{ }^{2} J_{H H}=0.63 \mathrm{~Hz}\right), 7.44(\mathrm{~m}, 1 \mathrm{H}), 7.34(\mathrm{~m}, 1 \mathrm{H}), 3.5-1.5\left(\mathrm{~m}, 9 \mathrm{H}, \mathrm{B}_{\text {carborane- }}\right)$, $3.10\left(\mathrm{~s}, 2 \mathrm{H}, \mathrm{C}_{\text {carborane- }} \mathrm{H}\right)$

${ }^{13} \mathbf{C}\left\{{ }^{1} \mathbf{H}\right\}$ NMR (100 $\left.\mathbf{~ M H z}, \mathbf{C D C l}_{3}\right): \delta 155.86,152.03,136.74,125.69,124.77,123.19$, $121.27,54.73$

${ }^{11}$ B NMR (128 MHz): $\delta-3.95(\mathrm{~s}, 1 \mathrm{~B}),-6.38\left(\mathrm{~d}, 2 \mathrm{~B},{ }^{1} J_{B H}=162 \mathrm{~Hz}\right),-9.64\left(\mathrm{~d}, 1 \mathrm{~B},{ }^{1} J_{B H}=\right.$ $154 \mathrm{~Hz}),-12.95\left(\mathrm{~d}, 2 \mathrm{~B},{ }^{1} J_{B H}=154 \mathrm{~Hz}\right),-13.66\left(\mathrm{~d}, 2 \mathrm{~B},{ }^{1} J_{B H}=161 \mathrm{~Hz}\right),-17.32\left(\mathrm{~d}, 1 \mathrm{~B},{ }^{1} J_{B H}\right.$ $=183 \mathrm{~Hz}),-18.55\left(\mathrm{~d}, 1 \mathrm{~B},{ }^{1} J_{B H}=163 \mathrm{~Hz}\right)$ 
HRGC-MS m/z: 277.1914 (calc. 277.1928)

\section{9-(2)-7,8-dimethylquinoxaline-1,7-dicarba-closo-dodecaborane (5h)}

Procedure B

Isolation: Flash column chromatography, 15:85 Ethyl Acetate:Hexanes. Residual 9-HO$\mathrm{mCB}$ was removed by sublimation at $85^{\circ} \mathrm{C}$ and 0.1 torr

Yield: $33 \mathrm{mg}$ (44\%), pale yellow solid

${ }^{1}$ H NMR (400 MHz, CDCl3): $\delta 8.87(\mathrm{~s}, 1 \mathrm{H}), 7.91(\mathrm{~s}, 1 \mathrm{H}), 7.78(\mathrm{~s}, 1 \mathrm{H}), 3.60-1.60(\mathrm{~m}, 9 \mathrm{H}$, $\left.\mathrm{B}_{\text {carborane }}-\mathrm{H}\right), 3.11\left(\mathrm{~s}, 2 \mathrm{H}, \mathrm{C}_{\text {carborane }}-\mathrm{H}\right), 2.47(\mathrm{~s}, 6 \mathrm{H})$

${ }^{13} \mathbf{C}\left\{{ }^{1} \mathbf{H}\right\}$ NMR (100 MHz, CDCl$): \delta 139.85,139.82,128.95,128.11,54.77,20.33,20.22$

${ }^{11}$ B NMR (128 MHz): $\delta-1.87(\mathrm{~s}, 1 \mathrm{~B}),-6.38\left(\mathrm{~d}, 2 \mathrm{~B},{ }^{1} J_{B H}=164 \mathrm{~Hz}\right),-9.66\left(\mathrm{~d}, 1 \mathrm{~B},{ }^{1} J_{B H}=\right.$ $159 \mathrm{~Hz}),-12.90\left(\mathrm{~d}, 2 \mathrm{~B},{ }^{1} J_{B H}=159 \mathrm{~Hz}\right),-13.58\left(\mathrm{~d}, 2 \mathrm{~B},{ }^{1} J_{B H}=148 \mathrm{~Hz}\right),-17.23\left(\mathrm{~d}, 1 \mathrm{~B},{ }^{1} J_{B H}\right.$ $=185 \mathrm{~Hz}),-18.76\left(\mathrm{~d}, 1 \mathrm{~B},{ }^{1} J_{B H}=176 \mathrm{~Hz}\right)$

HRGC-MS $m / z: 300.3110$ (calc. 300.2630)

\section{9-(2)-4-tert-butylpyridine-1,7-dicarba-closo-dodecaborane (5i)}

Procedure B

Isolation: Flash column chromatography, Hexanes to 3:7 Ethyl Acetate:Hexanes gradient Yield: $24 \mathrm{mg}$ (34\%), white solid

${ }^{1} \mathbf{H}$ NMR (400 MHz, CDCl 3$): \delta 8.59\left(\mathrm{dd}, 1 \mathrm{H},{ }^{1} J_{H H}=5.51 \mathrm{~Hz},{ }^{2} J_{H H}=0.51 \mathrm{~Hz}\right), 7.53(\mathrm{~d}$, $\left.1 \mathrm{H},{ }^{1} J_{H H}=1.58 \mathrm{~Hz}\right), 7.16\left(\mathrm{dd}, 1 \mathrm{H},{ }^{1} J_{H H}=5.46 \mathrm{~Hz},{ }^{2} J_{H H}=2.17 \mathrm{~Hz}\right), 3.6-1.5(\mathrm{~m}, 9 \mathrm{H}$, $\left.\mathrm{B}_{\text {carborane }} \mathrm{H}\right), 3.04\left(\mathrm{~s}, 2 \mathrm{H}, \mathrm{C}_{\text {carborane }}-\mathrm{H}\right), 1.30(\mathrm{~s}, 9 \mathrm{H})$

${ }^{13} \mathbf{C}\left\{{ }^{1} \mathbf{H}\right\}$ NMR (100 MHz, CDCl3): $\delta$ 158.46, 149.08, 125.14, 119.22, 54.40, 34.61, 30.53 ${ }^{11}$ B NMR (128 MHz): $\delta-0.93(\mathrm{~s}, 1 \mathrm{~B}),-6.55\left(\mathrm{~d}, 2 \mathrm{~B},{ }^{1} J_{B H}=161 \mathrm{~Hz}\right),-9.79\left(\mathrm{~d}, 1 \mathrm{~B},{ }^{1} J_{B H}=\right.$ $154 \mathrm{~Hz}),-13.04\left(\mathrm{~d}, 2 \mathrm{~B},{ }^{1} J_{B H}=145 \mathrm{~Hz}\right),-13.90\left(\mathrm{~d}, 2 \mathrm{~B},{ }^{1} J_{B H}=147 \mathrm{~Hz}\right),-17.47\left(\mathrm{~d}, 1 \mathrm{~B},{ }^{1} J_{B H}\right.$ $=183 \mathrm{~Hz}),-19.36\left(\mathrm{~d}, 1 \mathrm{~B},{ }^{1} J_{B H}=170 \mathrm{~Hz}\right)$

HRGC-MS $m / z: 277.2807$ (calc. 277.2834)

\section{General Procedures for Oxidation Reactions with $\mathbf{4 b}$ or $\mathbf{4 c}$}

The synthesis of compounds $\mathbf{6 a - d}$ followed identical procedures used in the synthesis of compounds $\mathbf{5 a}$ or $\mathbf{5 i}$, depending on substrate, where the addition of $\mathbf{3 a}$ was replaced with either $\mathbf{4 b}$ or $\mathbf{4 c}$.

9-O-(2,2,6,6-tetramethylpiperidin-1-yl)oxyl -1,2-dicarba-closo-dodecaborane (6a) Isolation: Flash column chromatography, Hexanes to 1:9 Ethyl Acetate:Hexanes gradient Yield: $21 \mathrm{mg}$ (70\%), light yellow solid

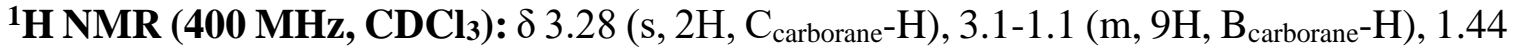
(s, 6H), $1.13(\mathrm{~s}, \mathrm{br}, 12 \mathrm{H})$

${ }^{13} \mathbf{C}\left\{{ }^{1} \mathbf{H}\right\}$ NMR (100 MHz, CDCl3): $\delta$ 60.54, 48.24, 40.19, 38.39, 34.94, 19.98, 17.11 
${ }^{11}$ B NMR (128 MHz): $\delta 16.21(\mathrm{~s}, 1 \mathrm{~B}),-4.52\left(\mathrm{~d}, 1 \mathrm{~B},{ }^{1} J_{B H}=144 \mathrm{~Hz}\right),-10.54\left(\mathrm{~d}, 2 \mathrm{~B},{ }^{1} J_{B H}=\right.$ $144 \mathrm{~Hz}),-17.20(\mathrm{~m}, 6 \mathrm{~B})$

HRGC-MS $m / z: 299.3131$ (calc. 299.3244)

3-O-(2,2,6,6-tetramethylpiperidin-1-yl)oxyl-1,2-dicarba-closo-dodecaborane (6b)

Isolation: Flash column chromatography, Hexanes to 1:9 Ethyl Acetate:Hexanes gradient Yield: $22 \mathrm{mg}$ (73\%), light yellow solid

${ }^{1} \mathbf{H}$ NMR (400 MHz, CDCl 3$): \delta 3.70\left(\mathrm{~s}, 2 \mathrm{H}, \mathrm{C}_{\text {carborane }}-\mathrm{H}\right), 3.0-1.0\left(\mathrm{~m}, 9 \mathrm{H}, \mathrm{B}_{\text {carborane }}-\mathrm{H}\right), 1.52$ (s, 6H), 1.21 (s, br, 12H)

${ }^{13} \mathbf{C}\left\{{ }^{1} \mathbf{H}\right\}$ NMR (100 MHz, CDCl $\left.\mathbf{3}\right): \delta 61.39,55.84,40.12,34.79,20.06,16.88$

${ }^{11}$ B NMR (128 MHz): $\delta 1.32(\mathrm{~s}, 1 \mathrm{~B}),-5.67\left(\mathrm{~d}, 1 \mathrm{~B},{ }^{1} J_{B H}=154 \mathrm{~Hz}\right),-11.30\left(\mathrm{~d}, 2 \mathrm{~B},{ }^{1} J_{B H}=\right.$ $145 \mathrm{~Hz}),-15.43(\mathrm{~m}, 5 \mathrm{~B}),-19.25\left(\mathrm{~d}, 1 \mathrm{~B},{ }^{1} J_{B H}=154 \mathrm{~Hz}\right)$

HRGC-MS $m / z: 299.3131$ (calc. 299.3244)

9-(2)-4-tert-butylpyridine-1,2-dicarba-closo-dodecaborane (6c)

Isolation: Flash column chromatography, Hexanes to 3:7 Ethyl Acetate:Hexanes gradient Yield: $9 \mathrm{mg}(33 \%)$, white solid

${ }^{1} \mathbf{H}$ NMR $\left(400 \mathrm{MHz}, \mathbf{C D C l}_{3}\right): \delta 8.55\left(\mathrm{~d}, 1 \mathrm{H},{ }^{1} J_{H H}=5.33 \mathrm{~Hz}\right), 7.39\left(\mathrm{~d}, 1 \mathrm{H},{ }^{1} J_{H H}=1.53 \mathrm{~Hz}\right)$, $7.11\left(\mathrm{dd}, 1 \mathrm{H},{ }^{1} J_{H H}=5.27 \mathrm{~Hz},{ }^{2} J_{H H}=1.76 \mathrm{~Hz}\right), 3.70\left(\mathrm{~s}, 1 \mathrm{H}, \mathrm{C}_{\text {carborane- }} \mathrm{H}\right), 3.60(\mathrm{~s}, 1 \mathrm{H}$, $\left.\left.\mathrm{C}_{\text {carborane }}-\mathrm{H}\right), 3.1-1.5\left(\mathrm{~m}, 9 \mathrm{H}, \mathrm{B}_{\text {carborane- }} \mathrm{H}\right)\right), 1.28(\mathrm{~s}, 9 \mathrm{H})$

${ }^{13} \mathbf{C}\left\{{ }^{1} \mathbf{H}\right\}$ NMR (100 MHz, $\left.\mathbf{C D C l}_{3}\right): \delta 158.27,149.91,124.43,118.92,53.38,50.01,34.59$, 30.53

${ }^{11}$ B NMR (128 MHz): $\delta 6.32(\mathrm{~s}, 1 \mathrm{~B}),-2.34\left(\mathrm{~d}, 1 \mathrm{~B},{ }^{1} J_{B H}=142 \mathrm{~Hz}\right),-8.78\left(\mathrm{~d}, 2 \mathrm{~B},{ }^{1} J_{B H}=150\right.$ $\mathrm{Hz}),-14.40(\mathrm{~m}, 6 \mathrm{~B})$

HRGC-MS $m / z: 277.2813$ (calc. 277.2834)

3-(2)-4-tert-butylpyridine-1,2-dicarba-closo-dodecaborane (6d)

Isolation: Flash column chromatography, Hexanes to 3:7 Ethyl Acetate:Hexanes gradient Yield: $10 \mathrm{mg}(36 \%)$, white solid

${ }^{1} \mathbf{H}$ NMR (400 MHz, CDCl $): \delta 8.44\left(\mathrm{dd}, 1 \mathrm{H},{ }^{1} J_{H H}=5.30 \mathrm{~Hz},{ }^{2} J_{H H}=0.66 \mathrm{~Hz}\right), 7.85(\mathrm{~d}$, $\left.1 \mathrm{H},{ }^{1} J_{H H}=1.32 \mathrm{~Hz}\right), 7.28\left(\mathrm{dd}, 1 \mathrm{H},{ }^{1} J_{H H}=5.36 \mathrm{~Hz},{ }^{2} J_{H H}=2.04 \mathrm{~Hz}\right), 4.08\left(\mathrm{~s}, 2 \mathrm{H}, \mathrm{C}_{\text {carborane- }}\right.$ $\left.\mathrm{H}, 3.3-1.4\left(\mathrm{~m}, 9 \mathrm{H}, \mathrm{B}_{\text {carborane }} \mathrm{H}\right)\right), 1.35$ (s, $\left.9 \mathrm{H}\right)$

${ }^{13} \mathbf{C}\left\{{ }^{1} \mathbf{H}\right\}$ NMR (100 MHz, $\left.\mathbf{C D C l}\right): \delta$ 159.39, 149.19, 126.50, 121.01, 57.28, 34.78, 30.52

${ }^{11}$ B NMR (128 MHz): $\delta-2.90\left(\mathrm{~d}, 2 \mathrm{~B},{ }^{1} J_{B H}=145 \mathrm{~Hz}\right),-7.11(\mathrm{~s}, 1 \mathrm{~B}),-12.79(\mathrm{~m}, 7 \mathrm{~B})$

HRGC-MS $m / z: 277.2807$ (calc. 277.2834) 


\section{X-ray Crystallography Details}

Table S8. Crystal data and structure refinement for $\mathbf{2 a}$.

CCDC number

Empirical formula

Formula weight

Temperature

Wavelength

Crystal system

Space group

Unit cell dimensions

Volume

Z

Density (calculated)

Absorption coefficient

$F(000)$

Crystal size

Theta range for data collection

Index ranges

Reflections collected

Independent reflections

Completeness to theta $=25.242^{\circ}$

Absorption correction

Max. and min. transmission

Refinement method

Data / restraints / parameters

Goodness-of-fit on $F^{2}$

Final R indices $[I>2 \sigma(I)]$

$R$ indices (all data)

Extinction coefficient

Largest diff. peak and hole
1967645

$\mathrm{C}_{8} \mathrm{H}_{23} \mathrm{~B}_{11} \mathrm{O}_{2}$

270.17

$100.0 \mathrm{~K}$

$0.71073 \AA$

Monoclinic

$P 21 / n$

$a=13.2848(13) \AA \quad \alpha=90^{\circ}$.

$b=17.384(2) \AA$

$\beta=91.954(5)^{\circ}$.

$c=14.224(3) \AA$

$3283.0(8) \AA^{3}$

$\gamma=90^{\circ}$.
8

$1.093 \mathrm{Mg} / \mathrm{m}^{3}$

$0.059 \mathrm{~mm}^{-1}$

1136

$0.32 \times 0.28 \times 0.25 \mathrm{~mm}^{3}$

1.851 to $25.380^{\circ}$.

$-16<=h<=11,-20<=k<=20,-17<=l<=17$

20454

$5982[R($ int $)=0.0471]$

$99.5 \%$

Semi-empirical from equivalents

0.7452 and 0.6989

Full-matrix least-squares on $F^{2}$

5982 / 0 / 387

\subsection{5}

$R 1=0.0509, \mathrm{w} R 2=0.1152$

$R 1=0.0832, \mathrm{w} R 2=0.1307$

n/a

0.287 and -0.274 e. $\AA^{-3}$

Table S9. Crystal data and structure refinement for 5a.

CCDC number

Empirical formula

Formula weight

Temperature

Wavelength

Crystal system

Space group

Unit cell dimensions
1967643

$\mathrm{C}_{11} \mathrm{H}_{29} \mathrm{~B}_{10} \mathrm{NO}$

299.45

$100.0 \mathrm{~K}$

$0.71073 \AA$

Orthorhombic

Pbca

$a=16.1941(6) \AA \quad \alpha=90^{\circ}$. 
Volume

Z

Density (calculated)

Absorption coefficient

$F(000)$

Crystal size

Theta range for data collection

Index ranges

Reflections collected

Independent reflections

Completeness to theta $=25.242^{\circ}$

Absorption correction

Max. and min. transmission

Refinement method

Data / restraints / parameters

Goodness-of-fit on $F^{2}$

Final $R$ indices $[I>2 \sigma(I)]$

$R$ indices (all data)

Extinction coefficient

Largest diff. peak and hole

$b=13.2477(4) \AA \quad \beta=90^{\circ}$.
$c=16.5076(4) \AA \quad \quad \AA^{\circ}$.
$3541.45(19) \AA^{3}$
8
$1.123 \mathrm{Mg} / \mathrm{m}^{3}$
$0.059 \mathrm{~mm}^{-1}$
1280
$0.32 \times 0.31 \times 0.28 \mathrm{~mm}^{3}$
2.338 to $28.281^{\circ}$.
$-17<=h<=21,-17<=k<=17,-21<=l<=21$
26580
$4392[R($ int $)=0.0559]$
$100.0 \%$
Semi-empirical from equivalents
0.7457 and 0.6931
Full-matrix least-squares on $F^{2}$
$4392 / 0 / 212$
1.051
$R 1=0.0482, \mathrm{w} R 2=0.1177$
$R 1=0.0635, \mathrm{w} R 2=0.1274$
n/a
0.323 and -0.288 e. $\AA^{-3}$

Table S10. Crystal data and structure refinement for $\mathbf{5 g}$.

CCDC number

Empirical formula

Formula weight

Temperature

Wavelength

Crystal system

Space group

Unit cell dimensions

Volume

Z

Density (calculated)

Absorption coefficient

$F(000)$

Crystal size

Theta range for data collection

Index ranges
1667644

$\mathrm{C}_{9} \mathrm{H}_{15} \mathrm{~B}_{10} \mathrm{NS}$

277.38

$100.0 \mathrm{~K}$

$0.71073 \AA$

Monoclinic

$P 21 / n$

$a=16.4854(6) \AA \quad \alpha=90^{\circ}$.

$b=9.7782(4) \AA \quad \beta=113.470(2)^{\circ}$.

$c=19.2767(7) \AA \quad \gamma=90^{\circ}$.

2850.28(19) $\AA^{3}$

8

$1.293 \mathrm{Mg} / \mathrm{m}^{3}$

$0.205 \mathrm{~mm}^{-1}$

1136

$0.33 \times 0.32 \times 0.3 \mathrm{~mm}^{3}$

1.380 to $28.355^{\circ}$.

$-20<=h<=22,-13<=k<=13,-25<=l<=25$ 
Reflections collected

Independent reflections

Completeness to theta $=25.242^{\circ}$

Absorption correction

Max. and min. transmission

Refinement method

Data / restraints / parameters

Goodness-of-fit on $F^{2}$

Final $R$ indices $[\mathrm{I}>2 \sigma(\mathrm{I})]$

$R$ indices (all data)

Extinction coefficient

Largest diff. peak and hole
25121

$7084[R($ int $)=0.0724]$

$100.0 \%$

Semi-empirical from equivalents

0.7457 and 0.6496

Full-matrix least-squares on $F^{2}$

7084 / 0 / 379

1.028

$R 1=0.0446, \mathrm{w} R 2=0.1159$

$R 1=0.0563, \mathrm{w} R 2=0.1256$

$\mathrm{n} / \mathrm{a}$

0.368 and -0.359 e. $\AA^{-3}$

Table S11. Crystal data and structure refinement for 5i.

CCDC number

Empirical formula

Formula weight

Temperature

Wavelength

Crystal system

Space group

Unit cell dimensions

Volume

$Z$

Density (calculated)

Absorption coefficient

$F(000)$

Crystal size

Theta range for data collection

Index ranges

Reflections collected

Independent reflections

Completeness to theta $=67.679^{\circ}$

Absorption correction

Max. and min. transmission

Refinement method

Data / restraints / parameters

Goodness-of-fit on $F^{2}$

Final $R$ indices $[I>2 \sigma(I)]$

$R$ indices (all data)
1967642

$\mathrm{C}_{11} \mathrm{H}_{23} \mathrm{~B}_{10} \mathrm{~N}$

277.40

$100.0 \mathrm{~K}$

$1.54178 \AA$

Monoclinic

$P 21 / c$

$a=11.0668(2) \AA \quad \alpha=90^{\circ}$.

$b=11.6755(2) \AA \quad \beta=91.0920(10)^{\circ}$.

$c=13.1623(2) \AA \quad \gamma=90^{\circ}$.

$1700.40(5) \AA^{3}$

4

$1.084 \mathrm{Mg} / \mathrm{m}^{3}$

$0.374 \mathrm{~mm}^{-1}$

584

$0.29 \times 0.28 \times 0.26 \mathrm{~mm}^{3}$

3.995 to $68.277^{\circ}$.

$-13<=h<=13,-14<=k<=13,-15<=l<=15$

21437

$3115[R($ int $)=0.0247]$

$100.0 \%$

Semi-empirical from equivalents

0.7531 and 0.6585

Full-matrix least-squares on $\mathrm{F}^{2}$

3115 / 0 / 202

1.099

$R 1=0.0456, \mathrm{w} R 2=0.1213$

$R 1=0.0480, \mathrm{w} R 2=0.1237$ 
Extinction coefficient

Largest diff. peak and hole

$\mathrm{n} / \mathrm{a}$

0.314 and -0.287 e. $\AA^{-3}$

Table S12. Crystal data and structure refinement for $6 \mathbf{6}$.

CCDC number

Empirical formula

Formula weight

Temperature

Wavelength

Crystal system

Space group

Unit cell dimensions

Volume

Z

Density (calculated)

Absorption coefficient

$F(000)$

Crystal size

Theta range for data collection

Index ranges

Reflections collected

Independent reflections

Completeness to theta $=67.679^{\circ}$

Absorption correction

Max. and min. transmission

Refinement method

Data / restraints / parameters

Goodness-of-fit on $F^{2}$

Final R indices $[I>2 \sigma(I)]$

$R$ indices (all data)

Extinction coefficient

Largest diff. peak and hole
1967641

C11 H29 B10 N O

299.45

$100.0 \mathrm{~K}$

$1.54178 \AA$

Orthorhombic

Pbca

$a=13.1543(5) \AA$

$\alpha=90^{\circ}$.

$b=16.2210(5) \AA$

$c=16.6984(5) \AA$

$3563.0(2) \AA^{3}$

8

$1.116 \mathrm{Mg} / \mathrm{m}^{3}$

$0.427 \mathrm{~mm}^{-1}$

1280

$0.31 \times 0.29 \times 0.27 \mathrm{~mm}^{3}$

5.075 to $68.154^{\circ}$.

$-15<=h<=15,-18<=k<=19,-20<=l<=19$

14603

$3224[R($ int $)=0.0284]$

$99.3 \%$

Semi-empirical from equivalents

0.7531 and 0.6802

Full-matrix least-squares on $F^{2}$

3224 / 0 / 212

1.024

$R 1=0.0475, \mathrm{w} R 2=0.1303$

$R 1=0.0522, \mathrm{w} R 2=0.1360$

$\mathrm{n} / \mathrm{a}$

0.309 and -0.359 e. $\AA^{-3}$ 


\section{References:}

1. Bruno, N. C.; Tudge, M. T.; Buchwald, S. L. Design and preparation of new palladium precatalysts for C-C and C-N cross-coupling reactions. Chem. Sci. 2013 4, 916-920

2. Spokoyny, A. M.; Machan, C. W.; Clingerman, D. J.; Rosen, M. S.; Weister, M. J.; Kennedy, R. D.; Stern, C. L.; Sarjeant, A. A.; Mirkin, C. A. A coordination chemistry dichotomy for icosahedral carborane-based ligands. Nature Chemistry 2011, 3, 590-596.

3. Anderson, K. P.; Mills, H. A.; Mao, C.; Kirlikovali, K. O.; Actell, J. C.; Rhenigold, A. L.; Spokoyny, A. M. Improved Synthesis of Icosahedral Carboranes Containing Exohedral B-C and C-C bonds. Tetrahedron 2019, 75, 187-191.

4. Lennox, A. J. J.; Lloyd-Jones, G. C. Preparation of Organotrifluoroborate Salts: Precipitation-Driven Equilibrium under Non-Etching Conditions. Angew. Chem. Int. Ed. 2012, 51, 9385-9388.

5. Chen, I-H.; Yin, L.; Itano, W.; Kanai, M.; Shibasaki, M. Catalytic Asymmetric Synthesis of Chiral Tertiary Organoboronic Esters through Conjugate Boration of $\beta$-Substituted Cyclic Enones. J. Am. Chem. Soc. 2009, 131, 33, 11664-11665.

6. Cheng, R.; Qiu, Z.; Xie, Z. Iridium-catalysed regioselective borylation of carboranes via direct B-H activation. Nature Communications 2017, 8, 14827.

7. O'Hara, F.; Blackmond, D. G.; Baran, P. S. Radical-Based Regioselective C-H Functionalization of Electron-Deficient Heteroarenes: Scope, Tunability, and Predictability. J. Am. Chem. Soc. 2013, 135, 32, 12122-12134. 


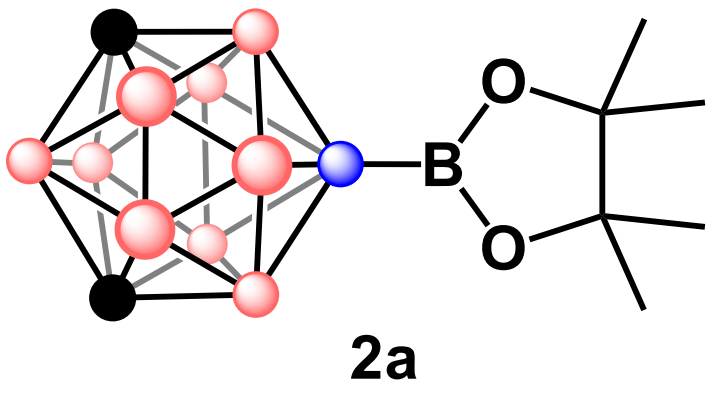

$\delta$
$\infty$
$\infty$

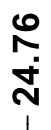

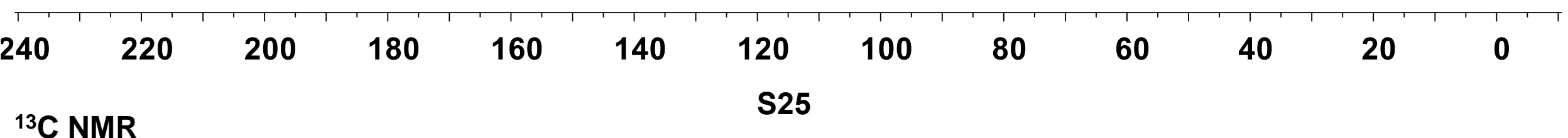




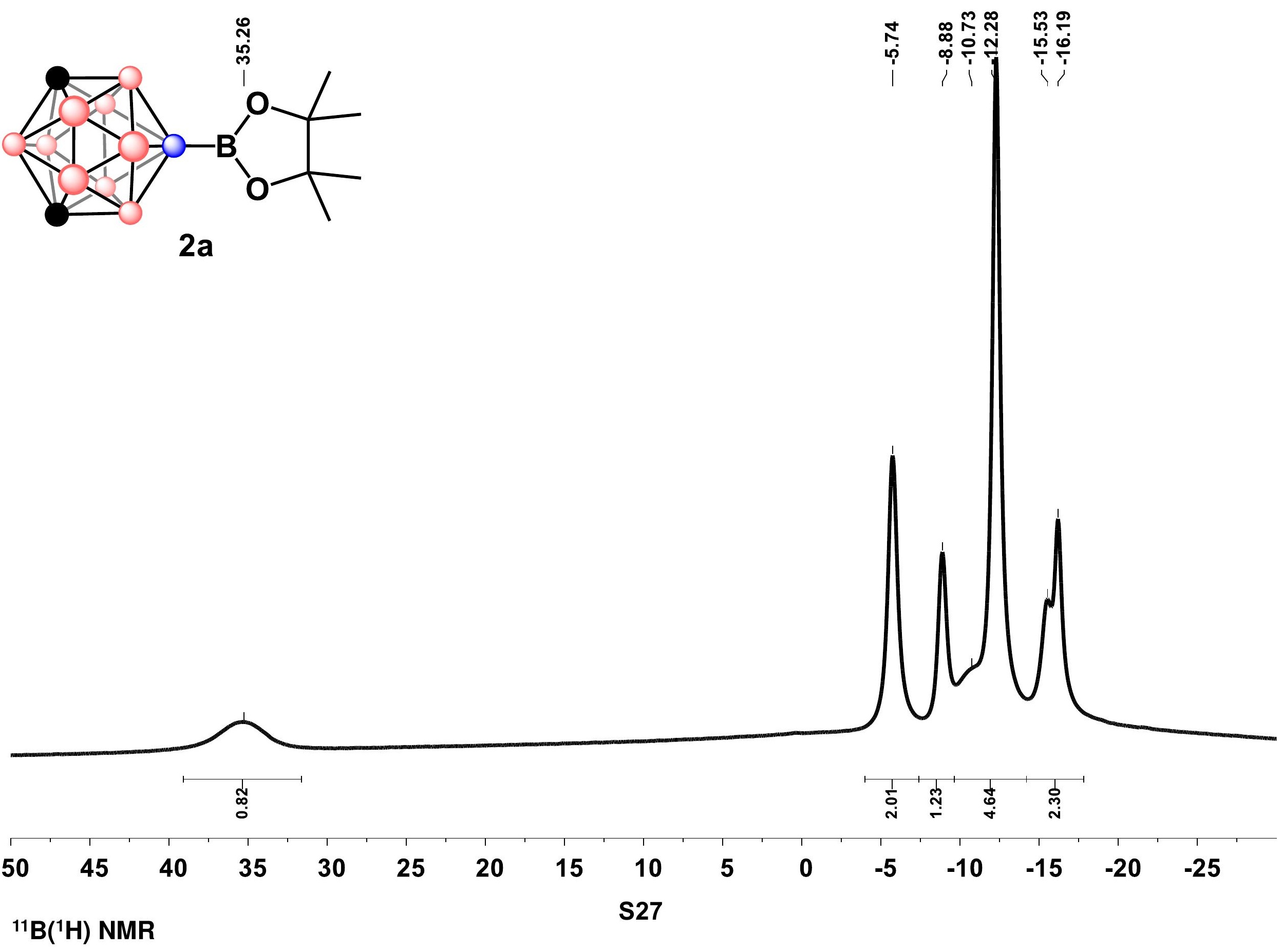




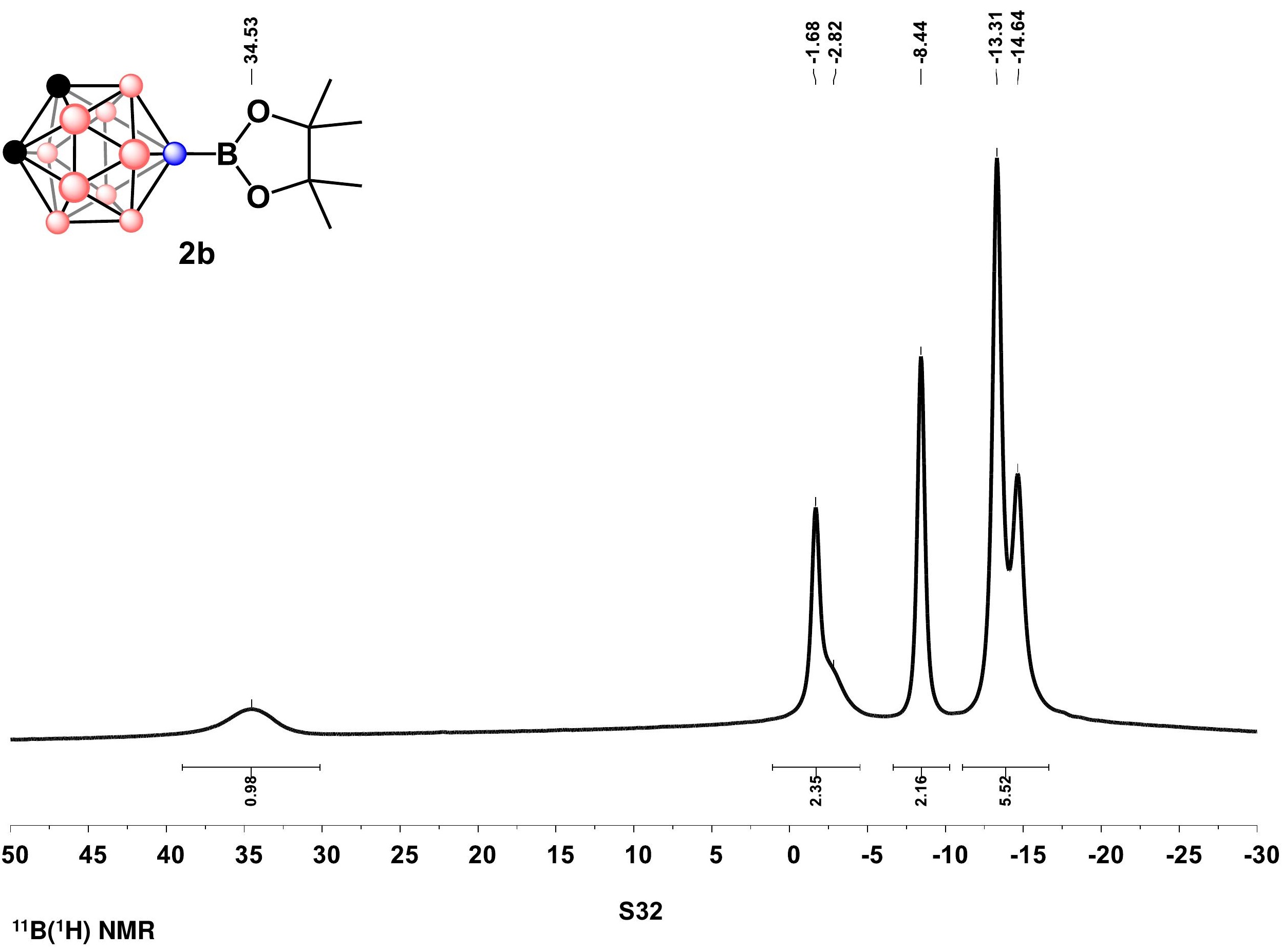



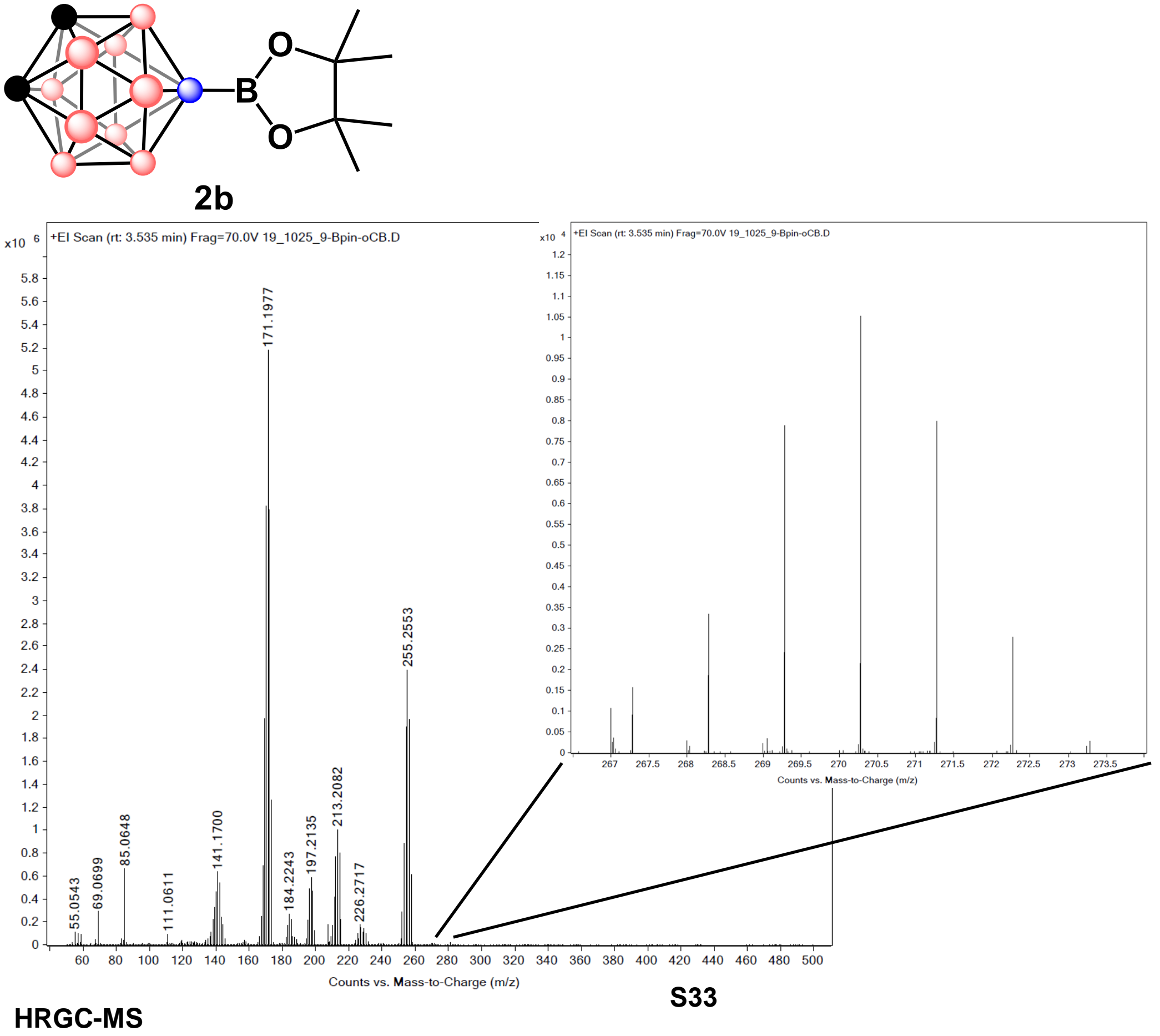


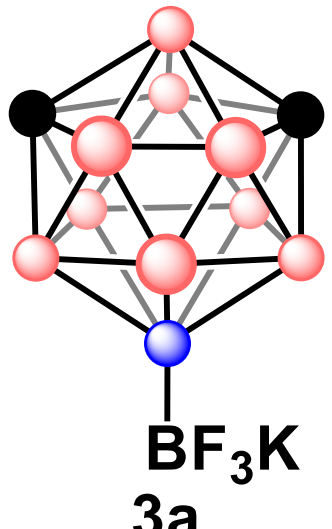

$3 a$ 


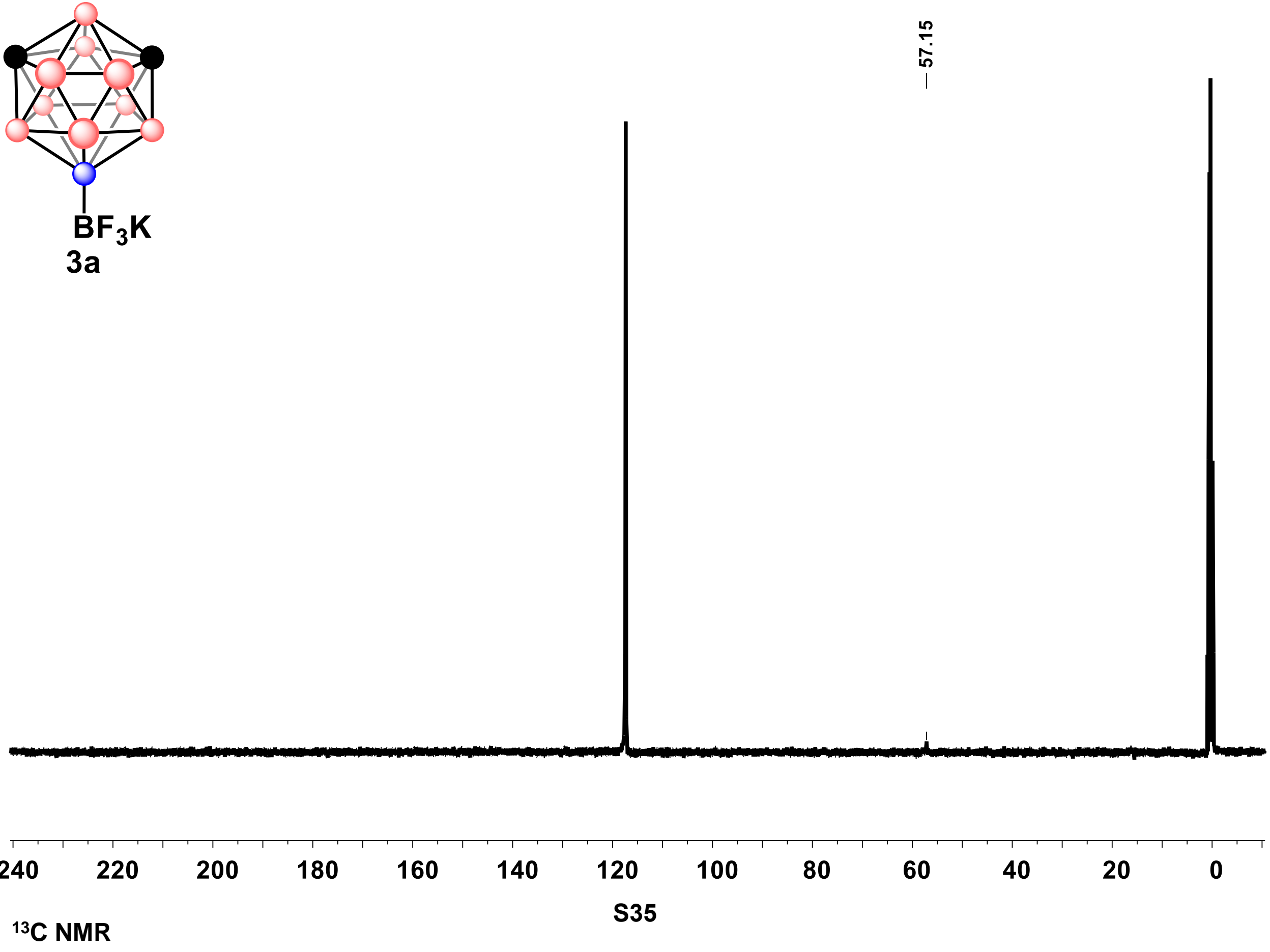



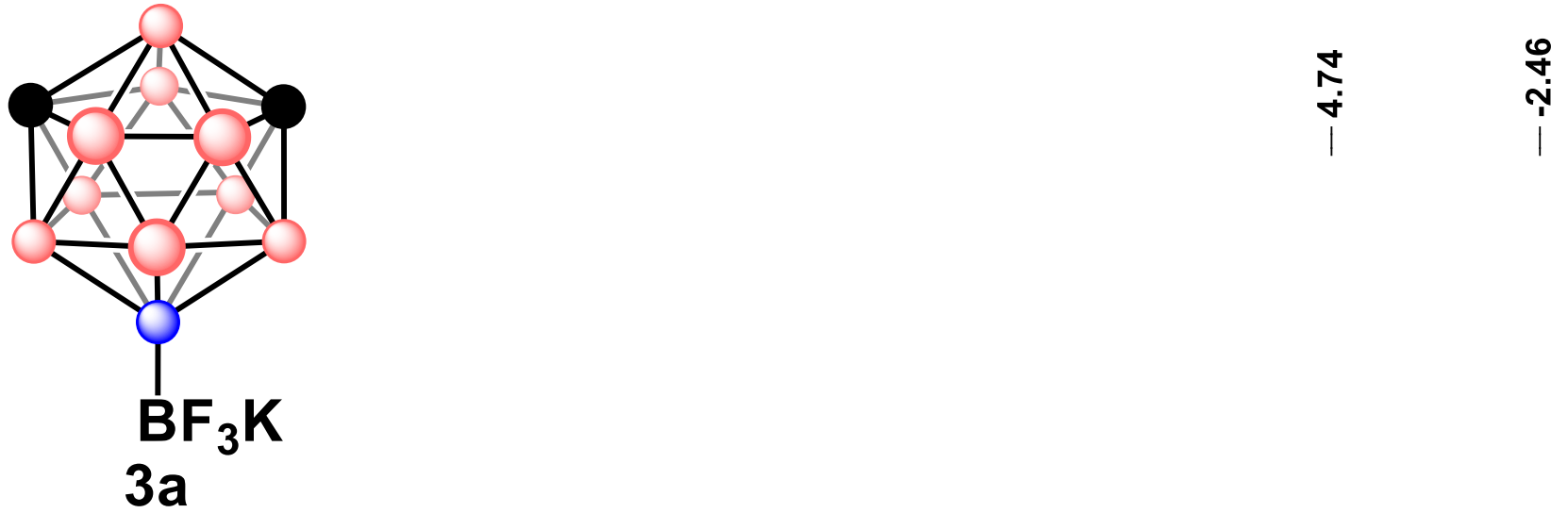

$\mathrm{BF}_{3} \mathrm{~K}$

3a

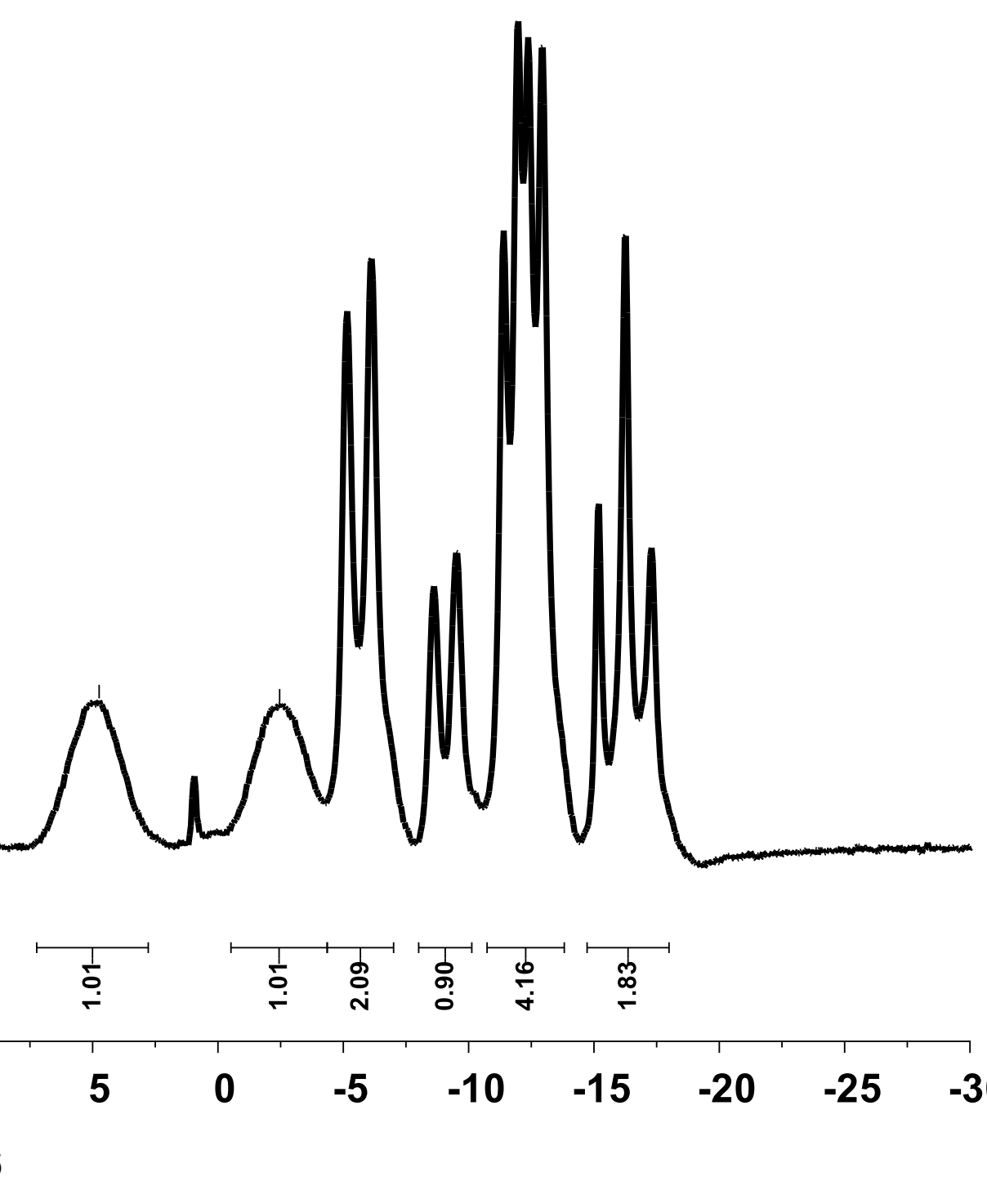
${ }^{11} B$ NMR

\begin{tabular}{|rrrrrrrrrrrrrrrrr}
\hline 50 & 45 & 40 & 35 & 30 & 25 & 20 & 15 & 10 & 5 & 0 & -5 & -10 & -15 & -20 & -25 & -3 \\
&
\end{tabular}




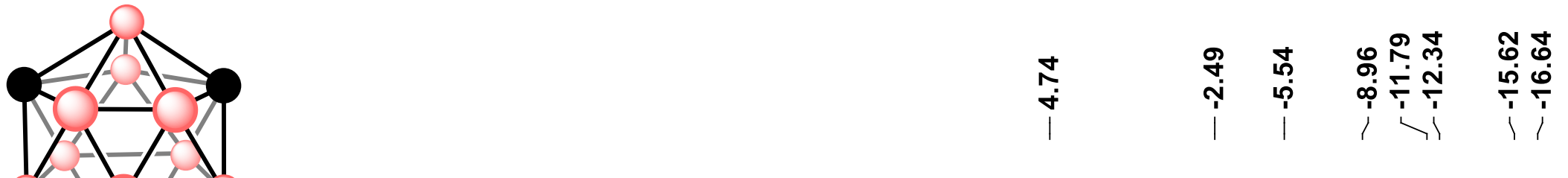

$\mathrm{BF}_{3} \mathrm{~K}$

$3 a$

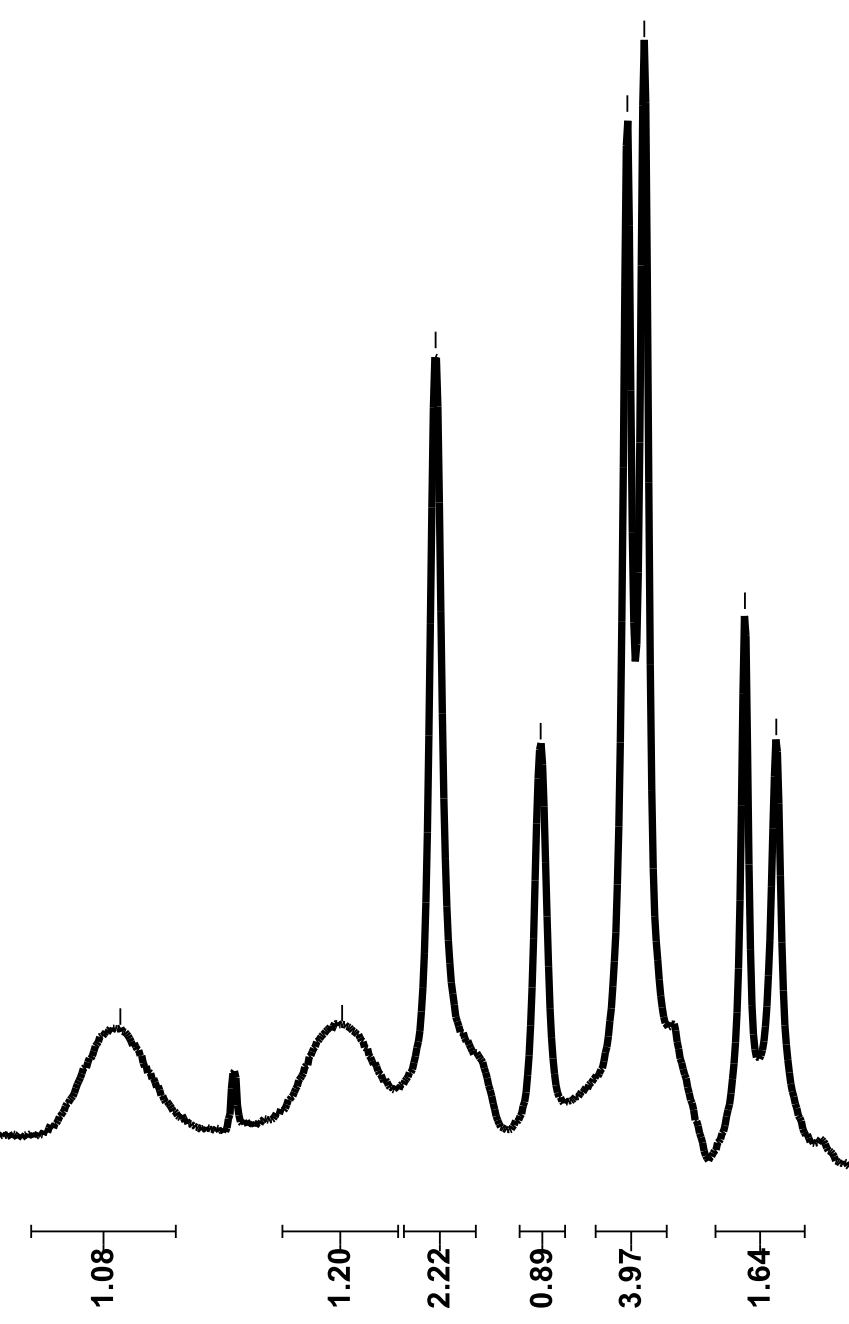

$\begin{array}{lllllllllllllllll}50 & 45 & 40 & 35 & 30 & 25 & 20 & 15 & 10 & 5 & 0 & -5 & -10 & -15 & -20 & -25 & -3\end{array}$ ${ }^{11} \mathrm{~B}\left({ }^{1} \mathrm{H}\right) \mathrm{NMR}$ 

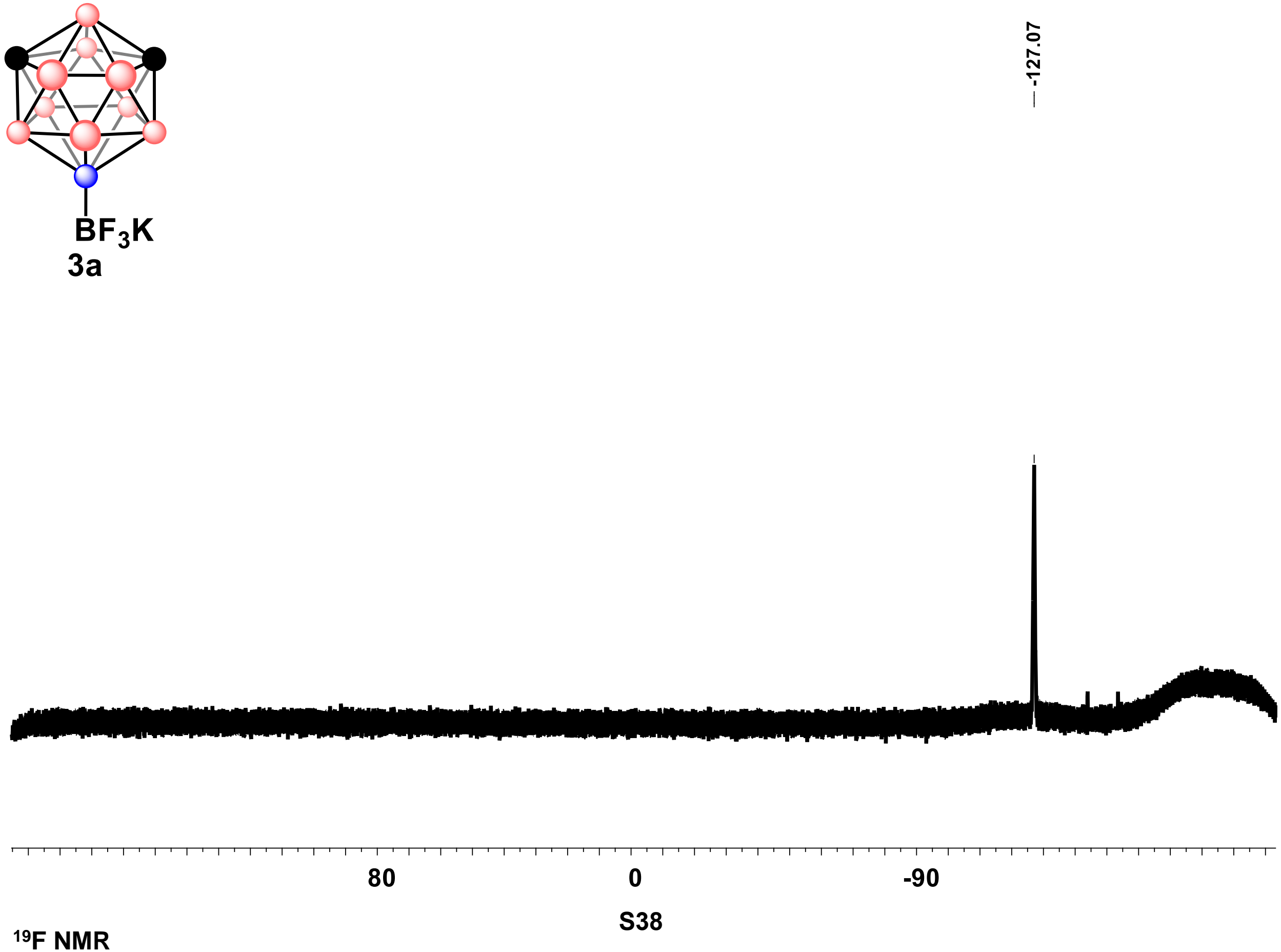


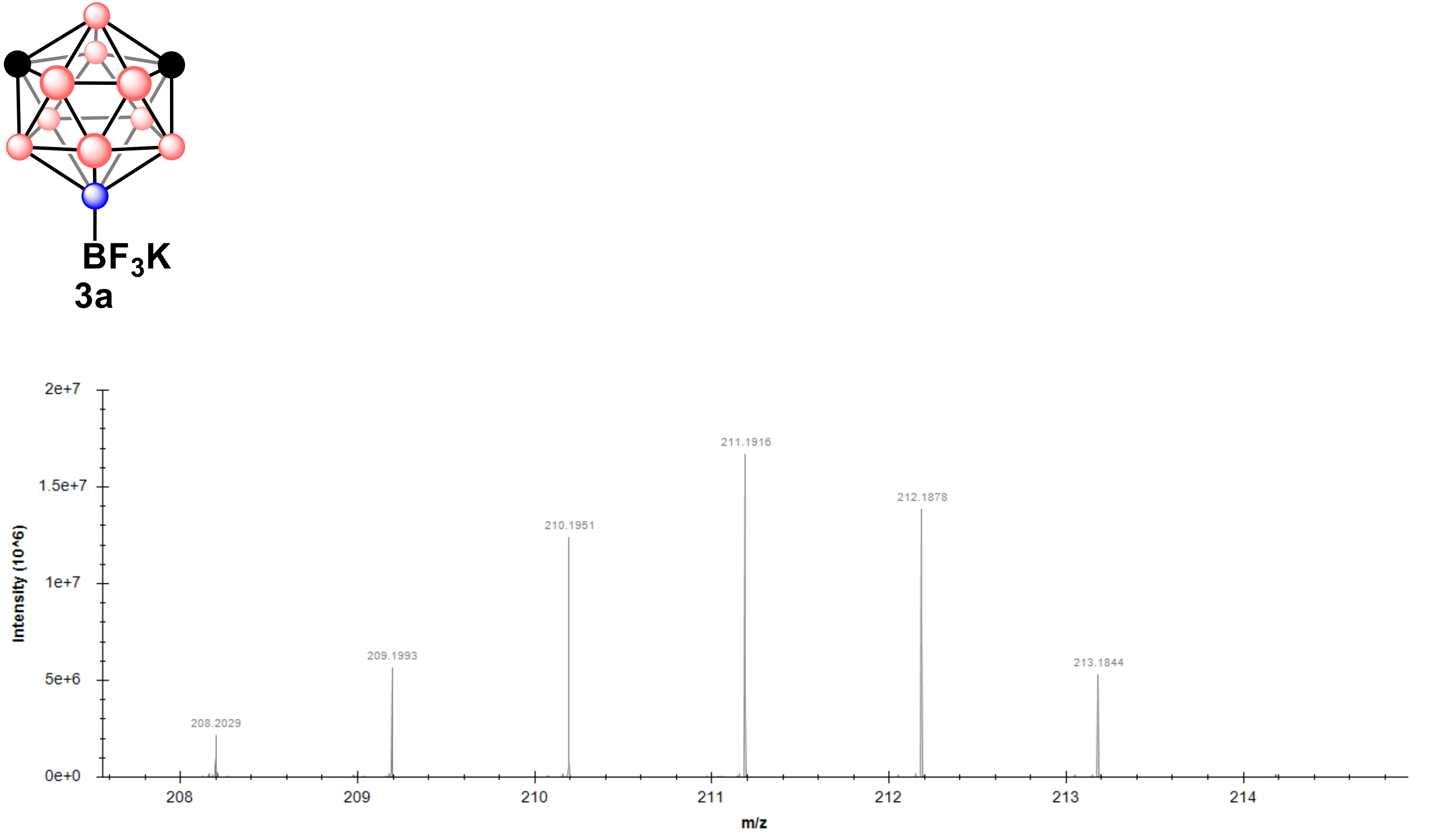




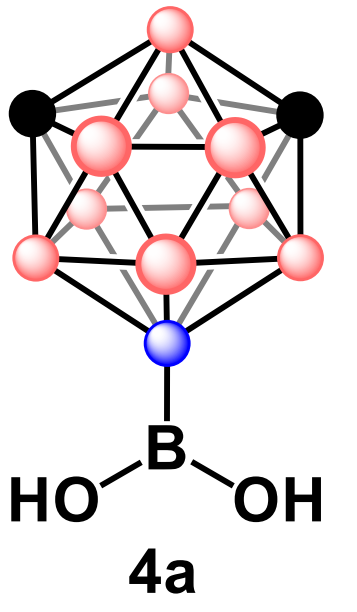

$\stackrel{m}{\infty}$

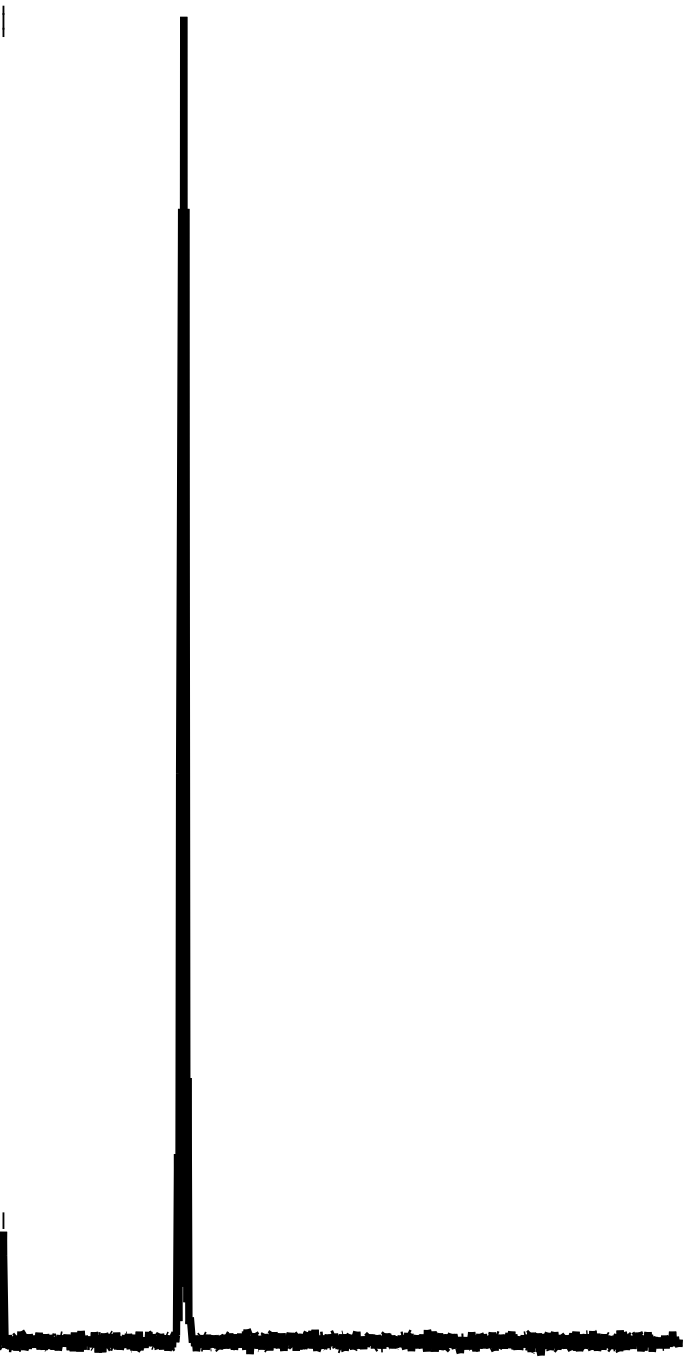

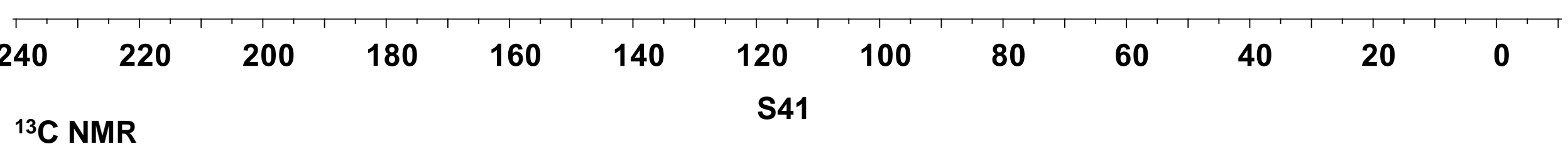




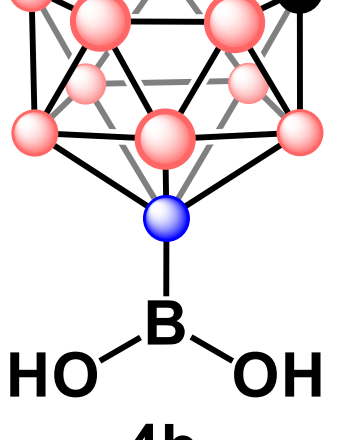

4b

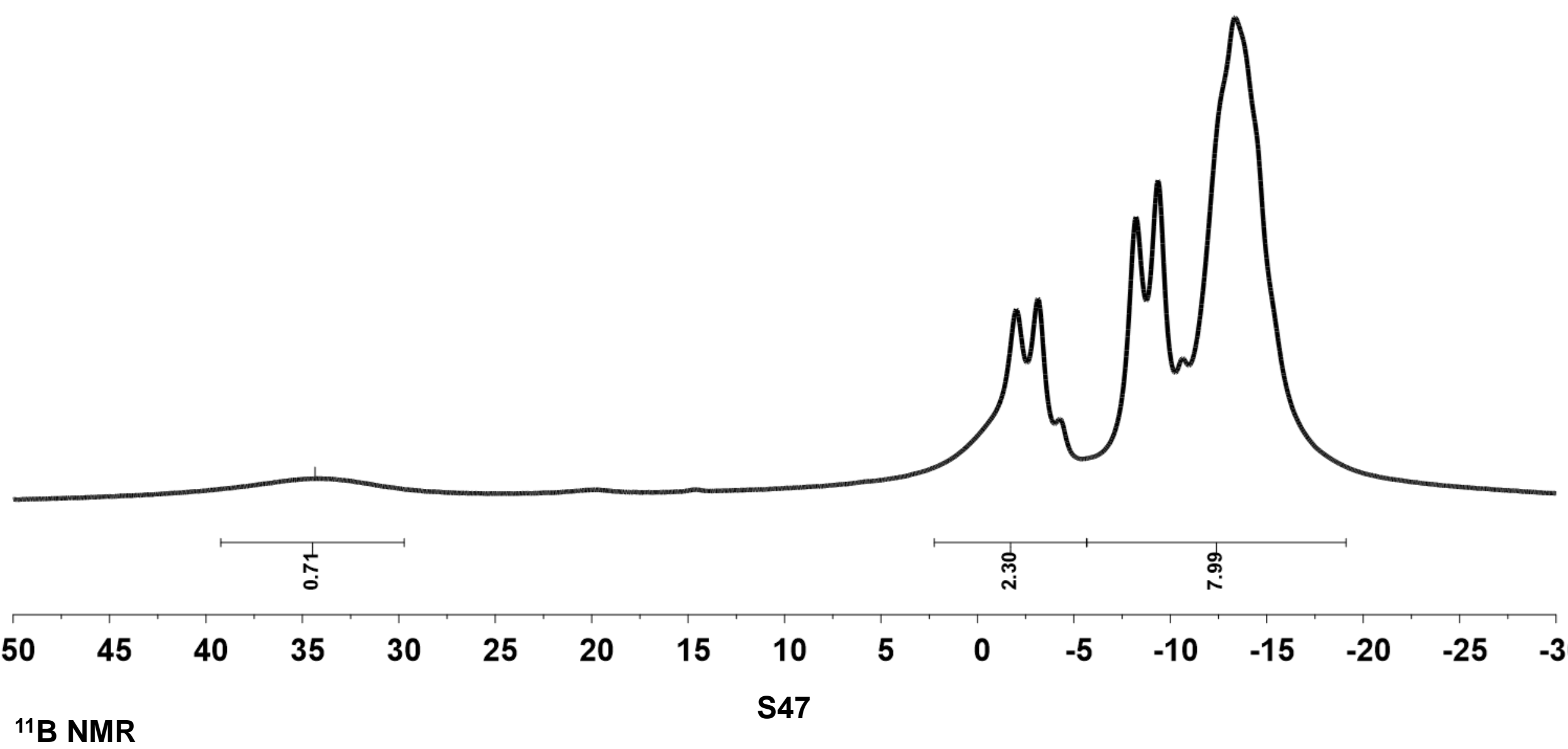




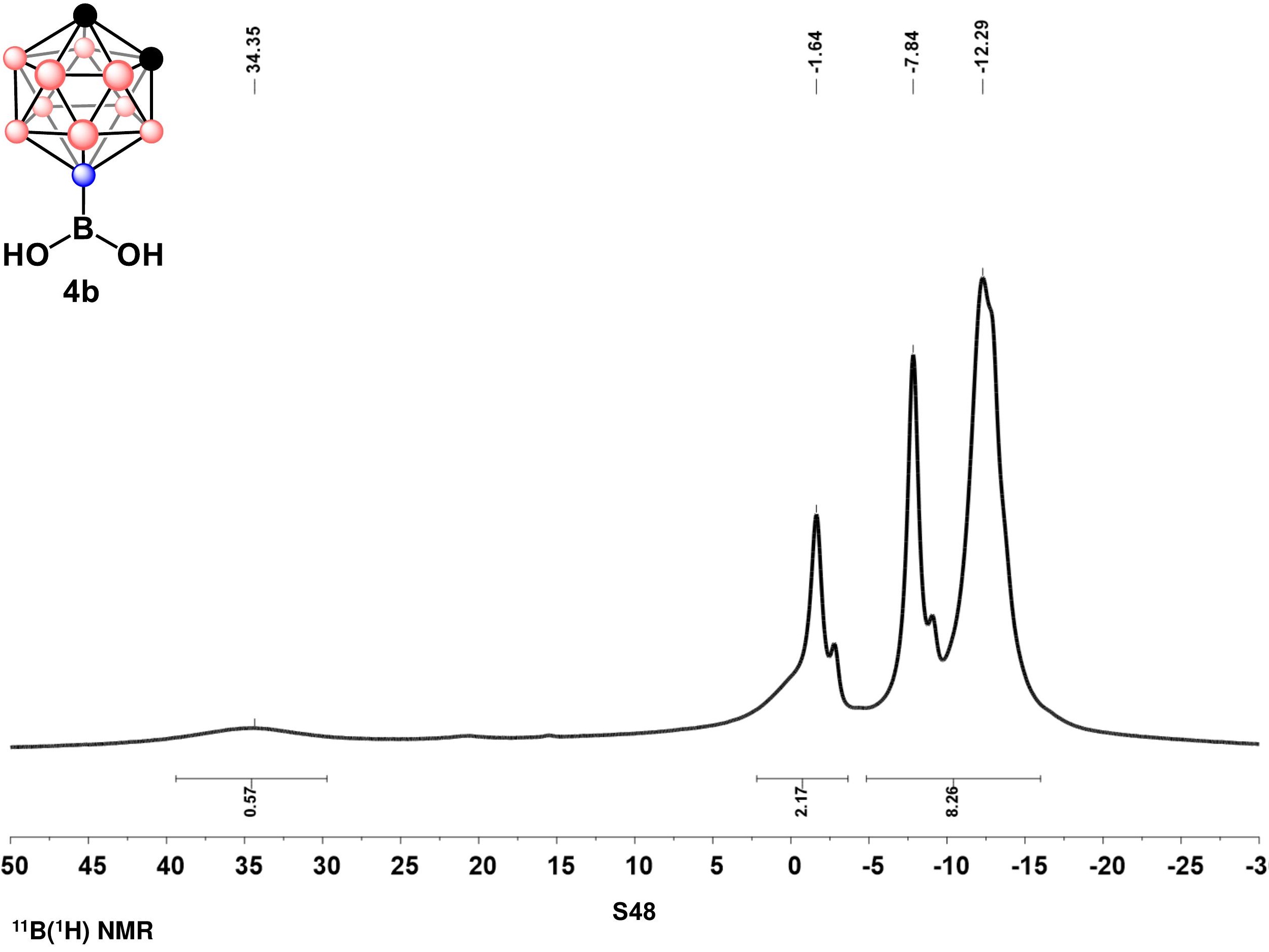




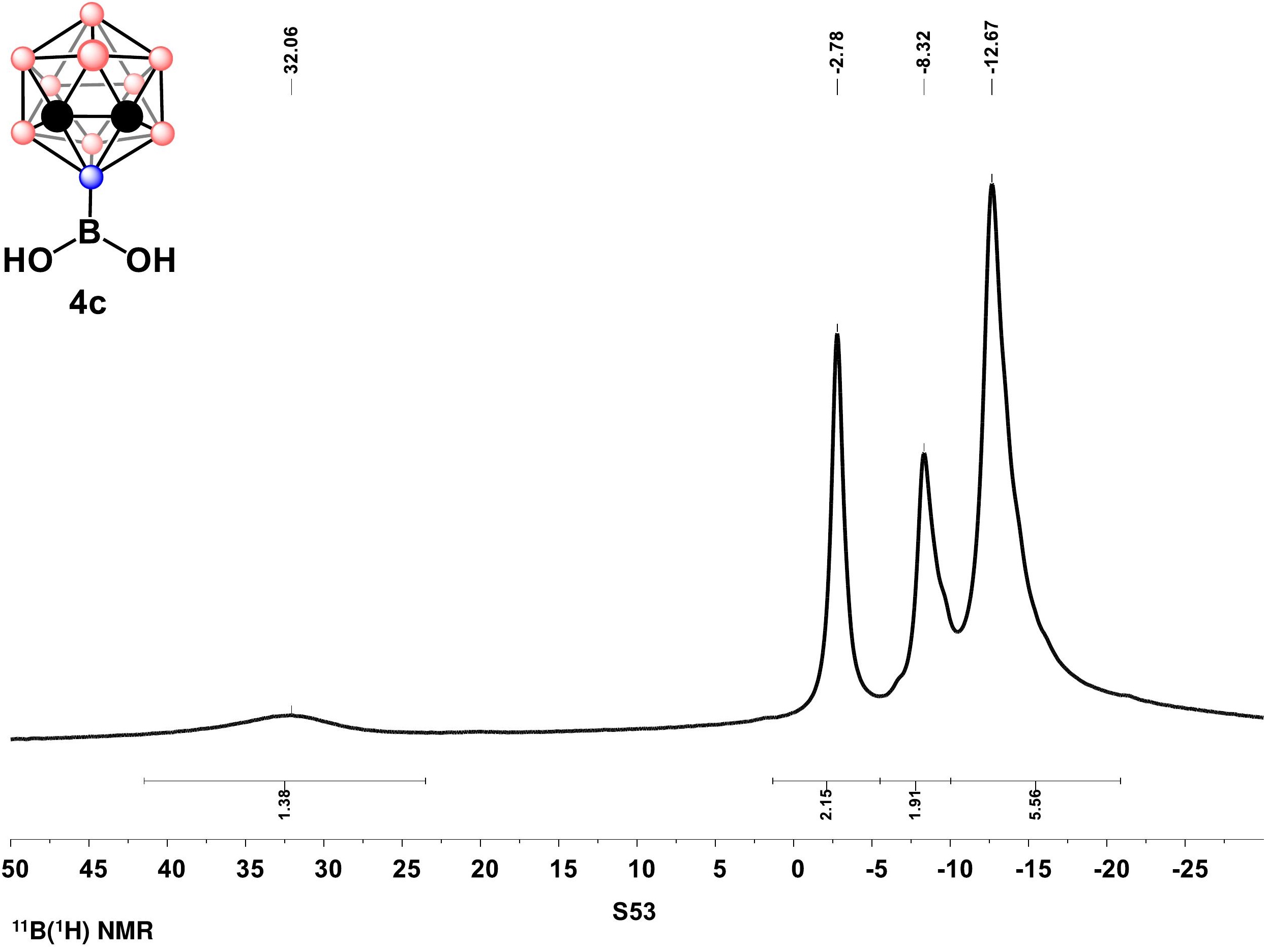




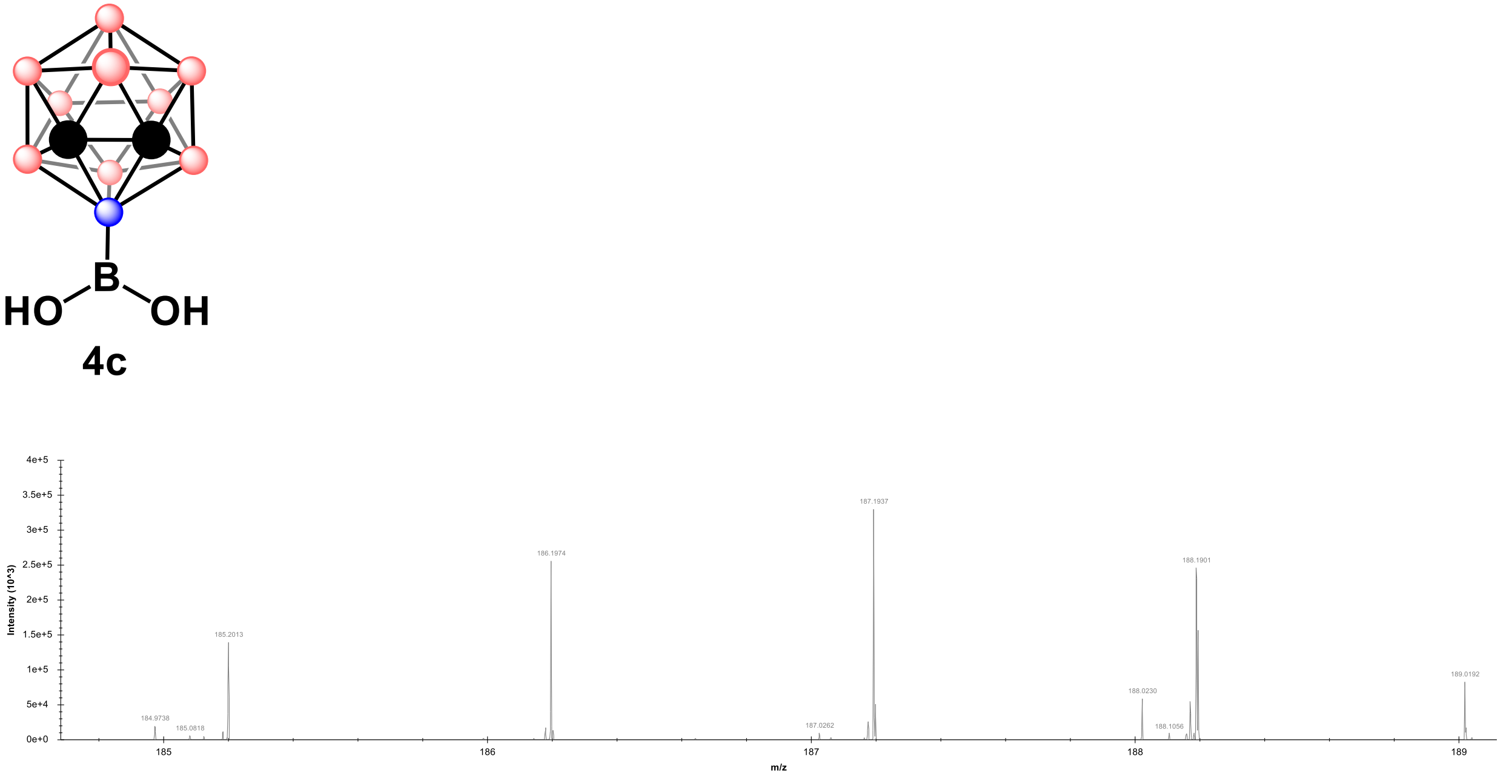

\section{DART-MS}




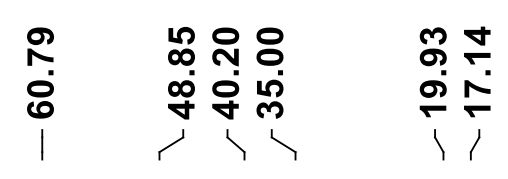

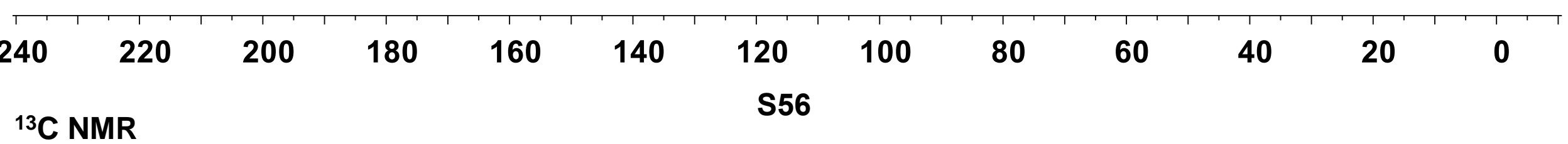




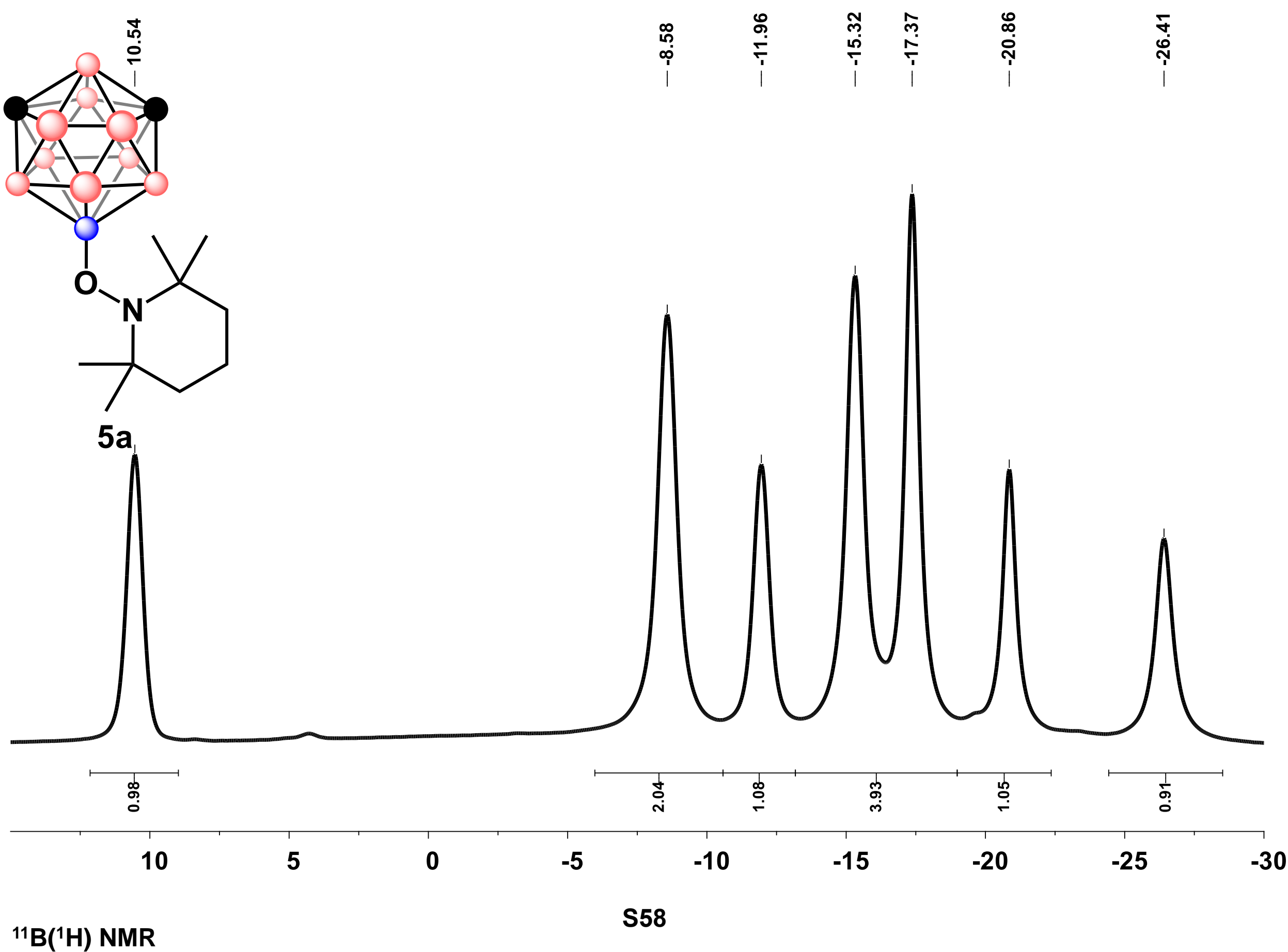




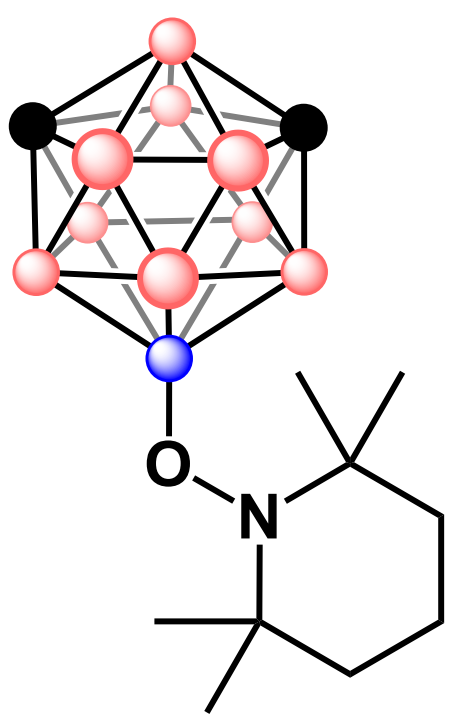

$5 a$

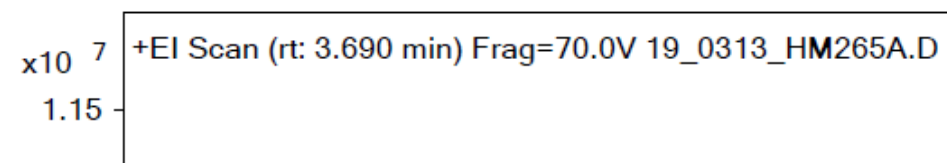

\section{HRGC-MS}

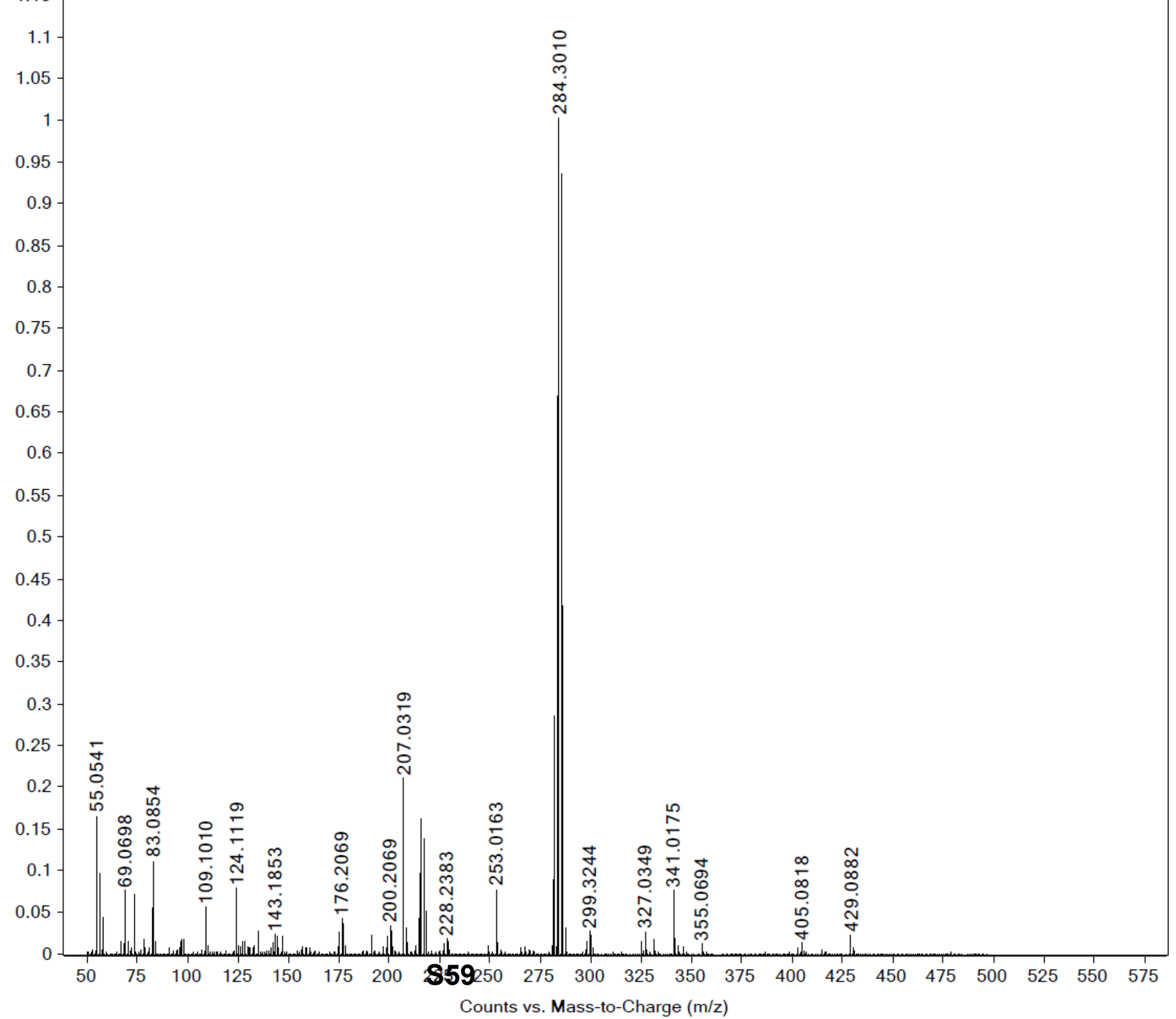


ํํำ

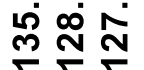

广र

นั

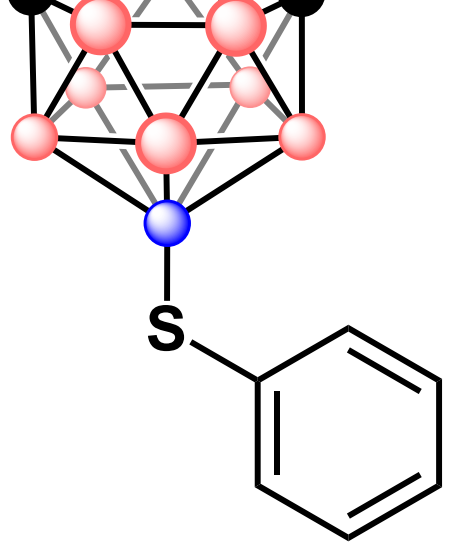

5b

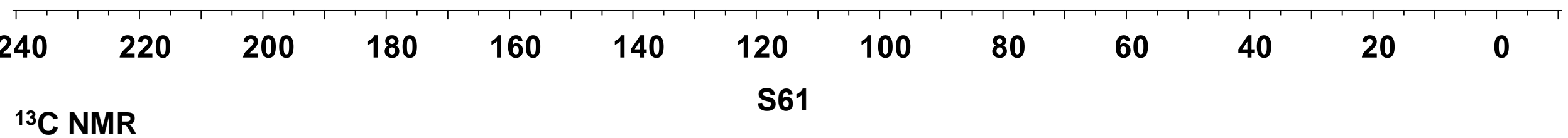




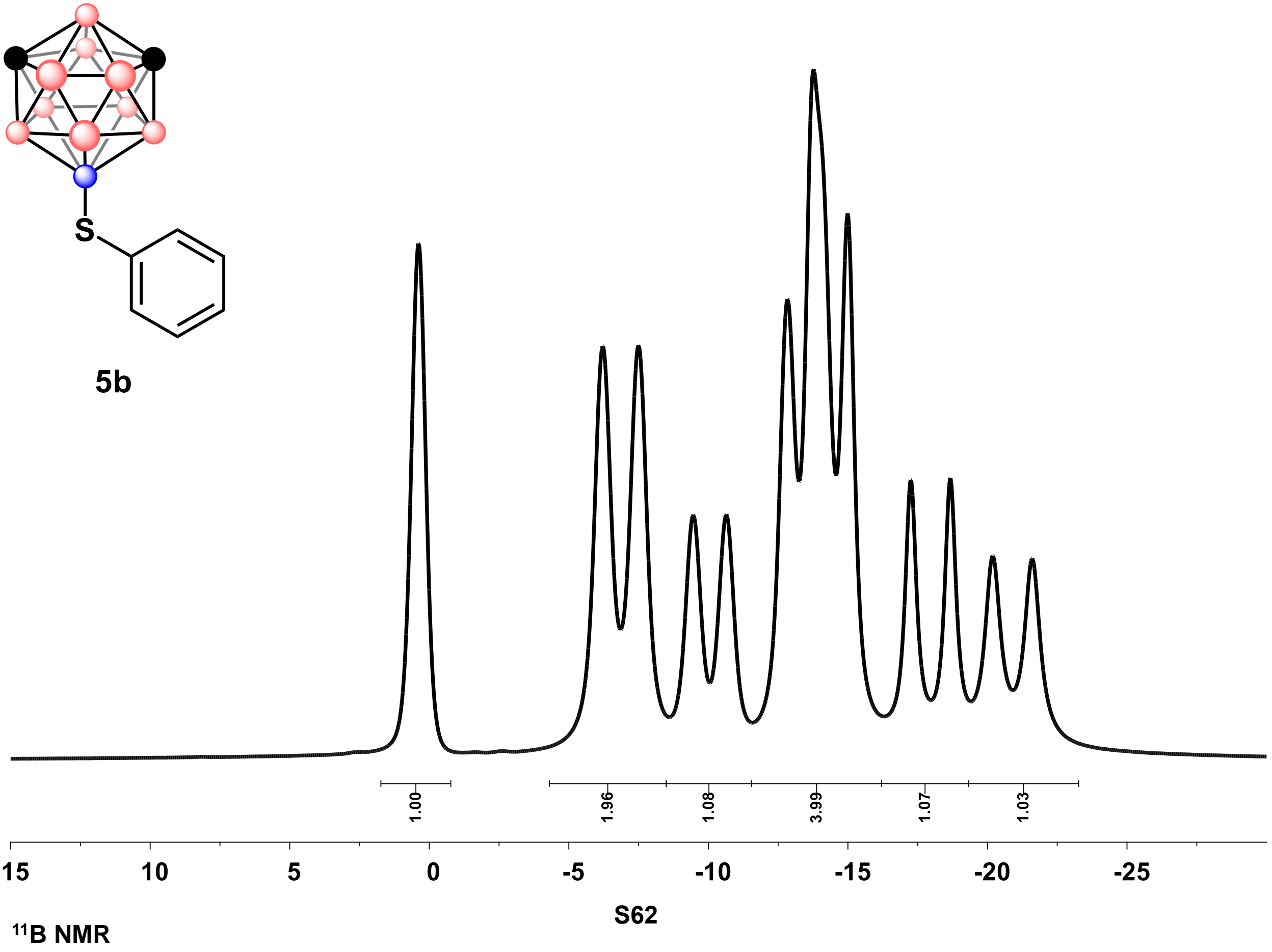




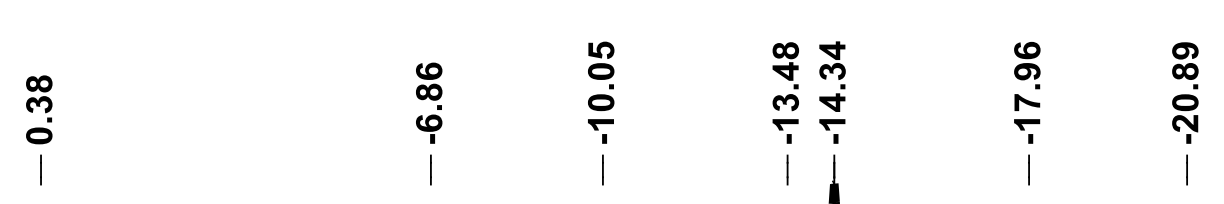

5b 


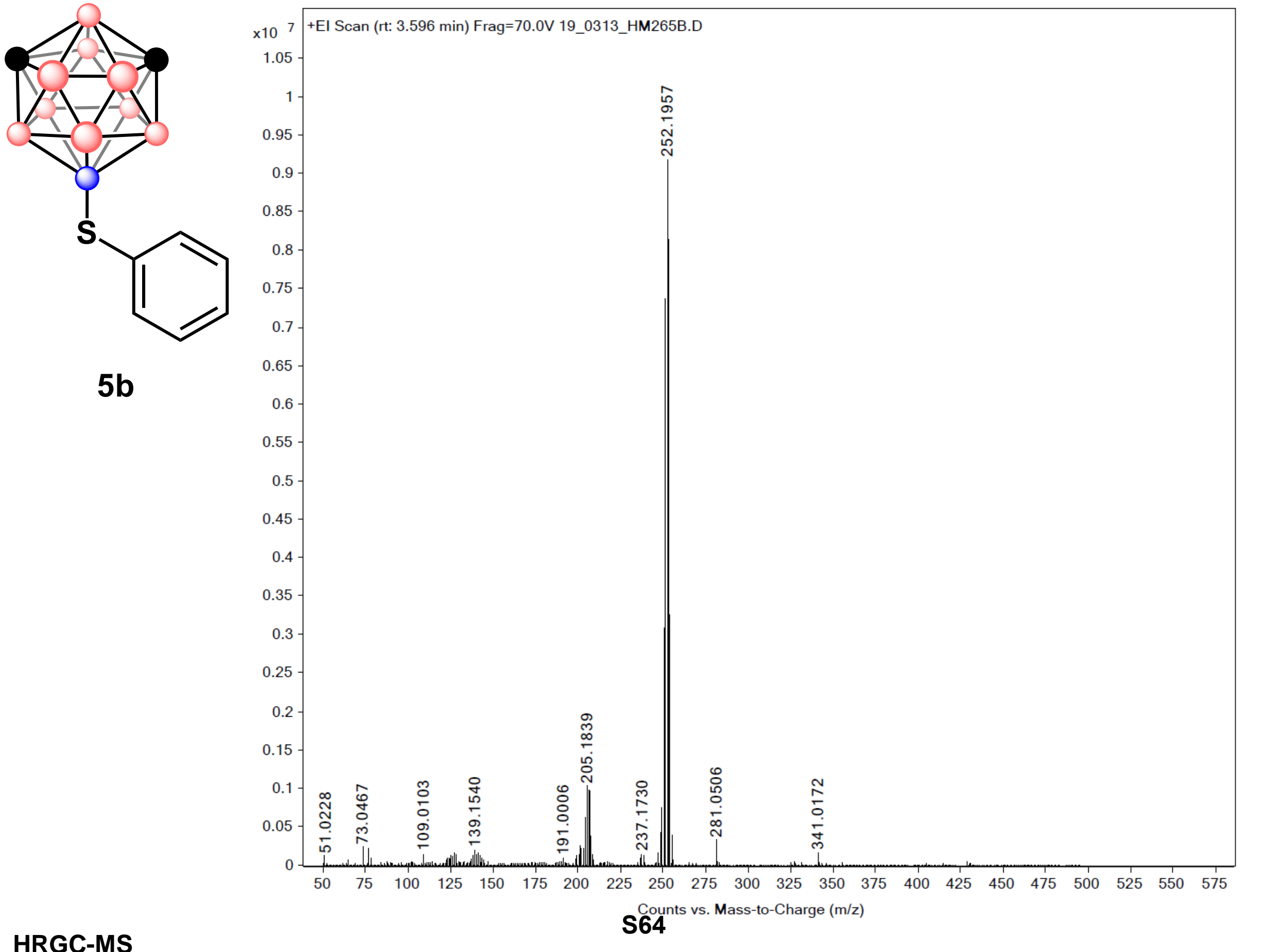

\section{HRGC-MS}




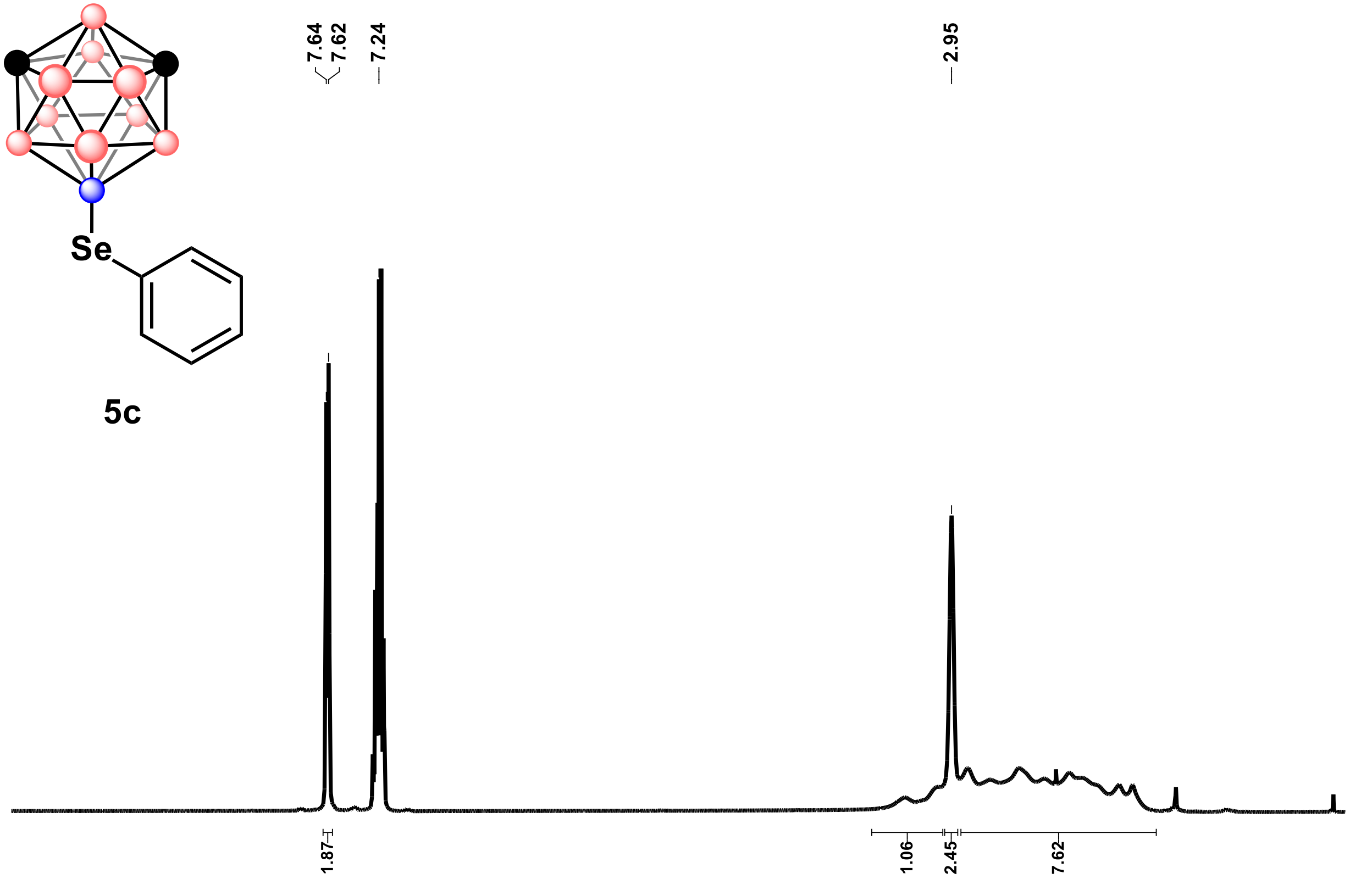

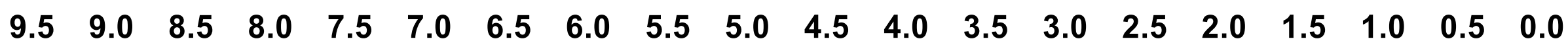
${ }^{1} \mathrm{H}$ NMR 


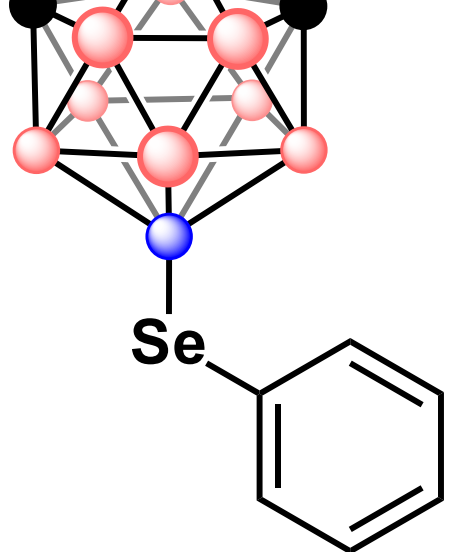

5c

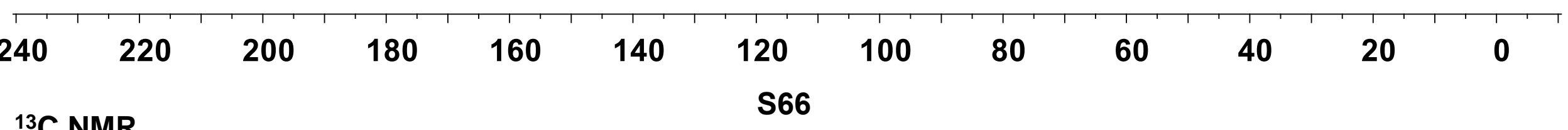
${ }^{13} \mathrm{C}$ NMR 


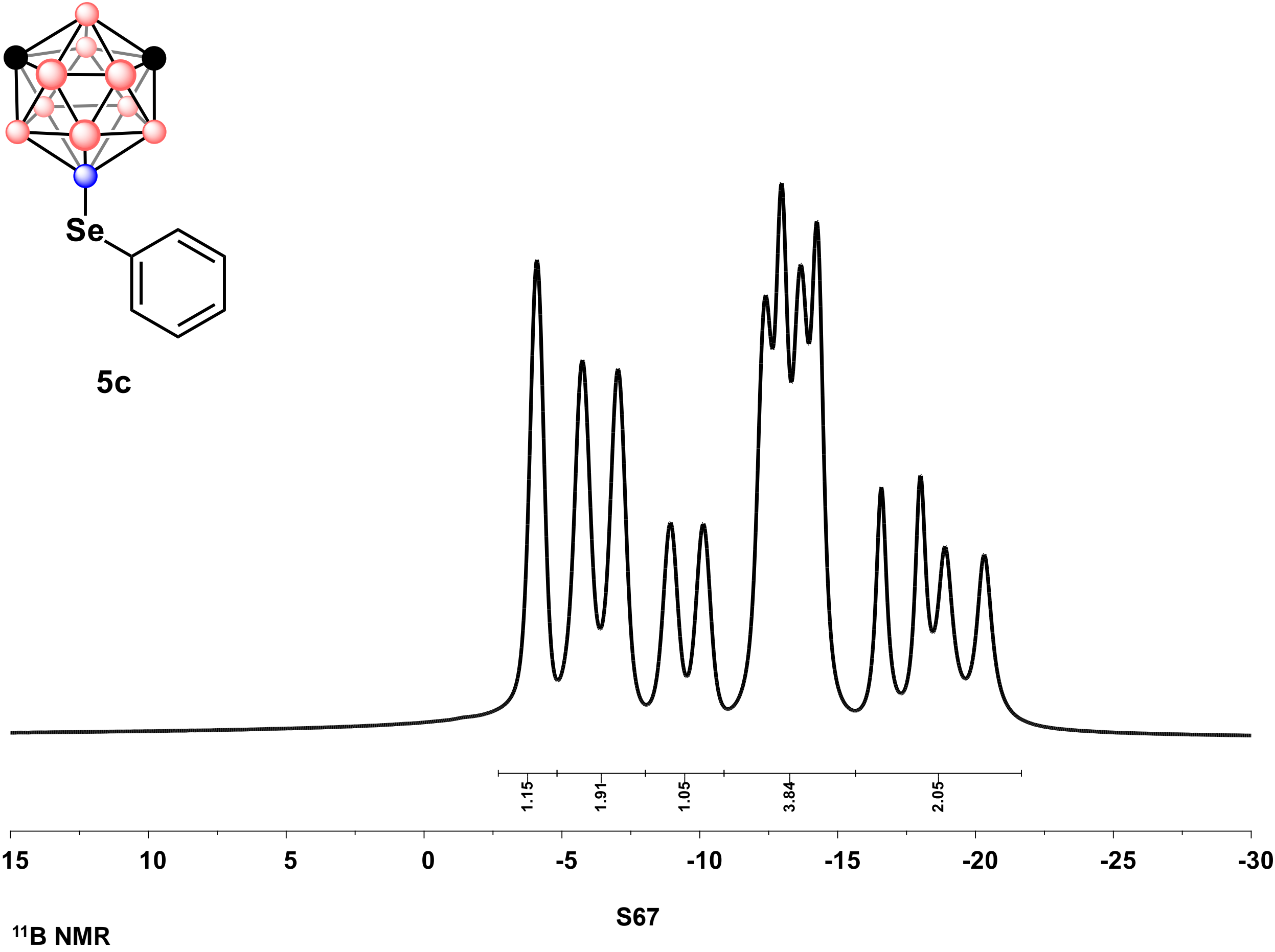




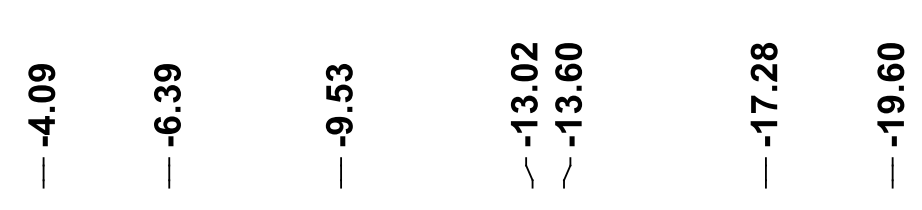

5c
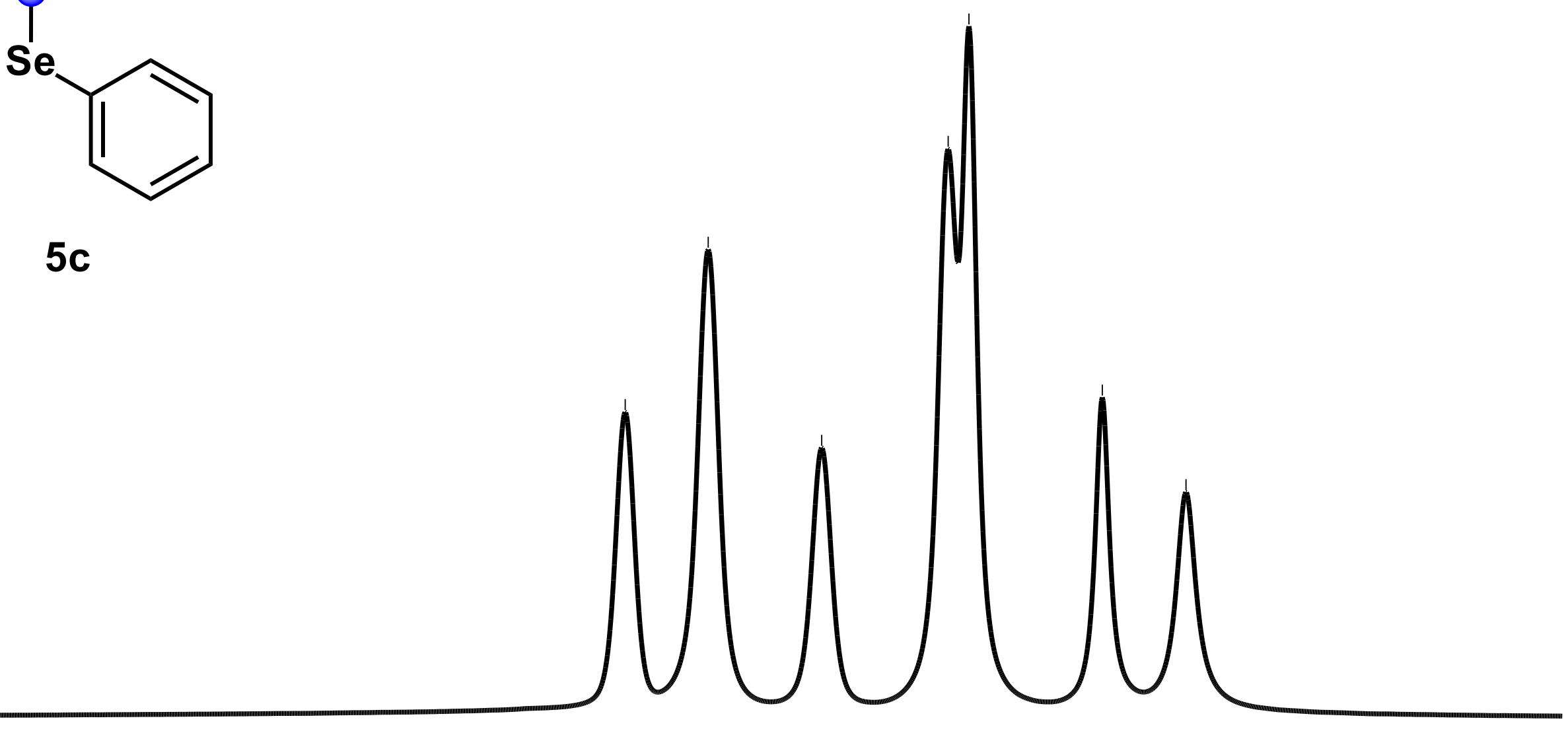

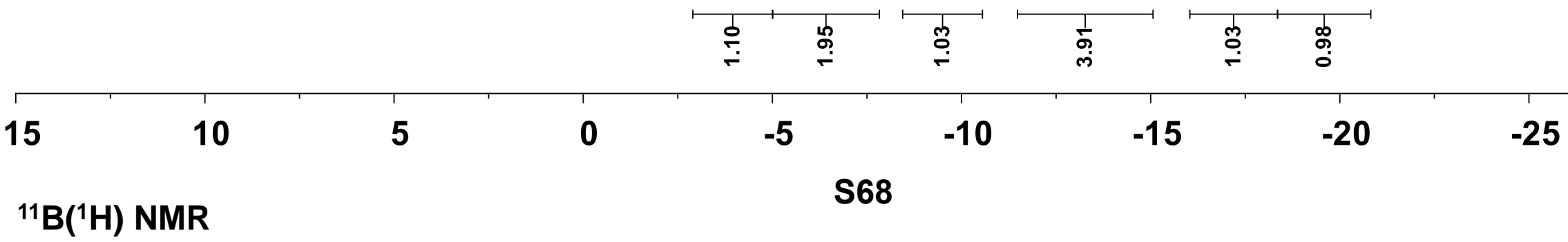


웅

-

$\backslash 11\}$

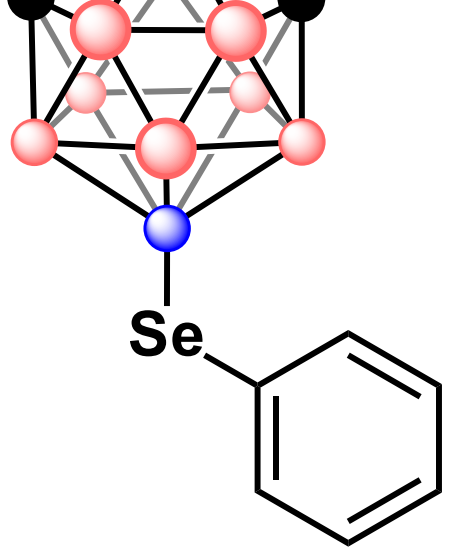

5c

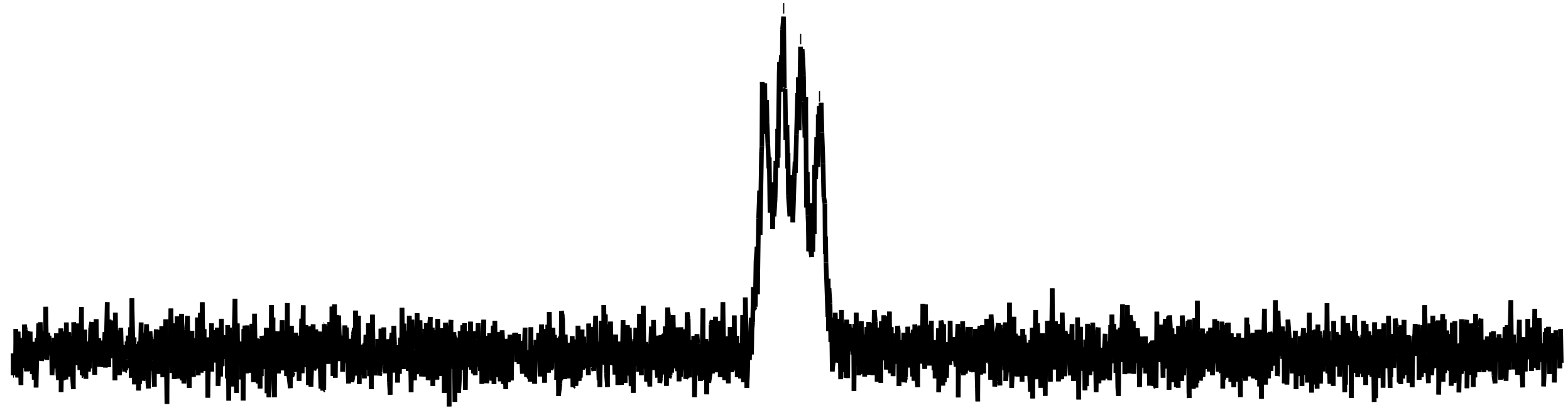




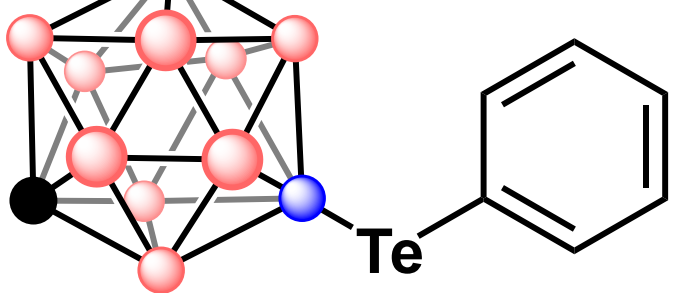

$5 d$

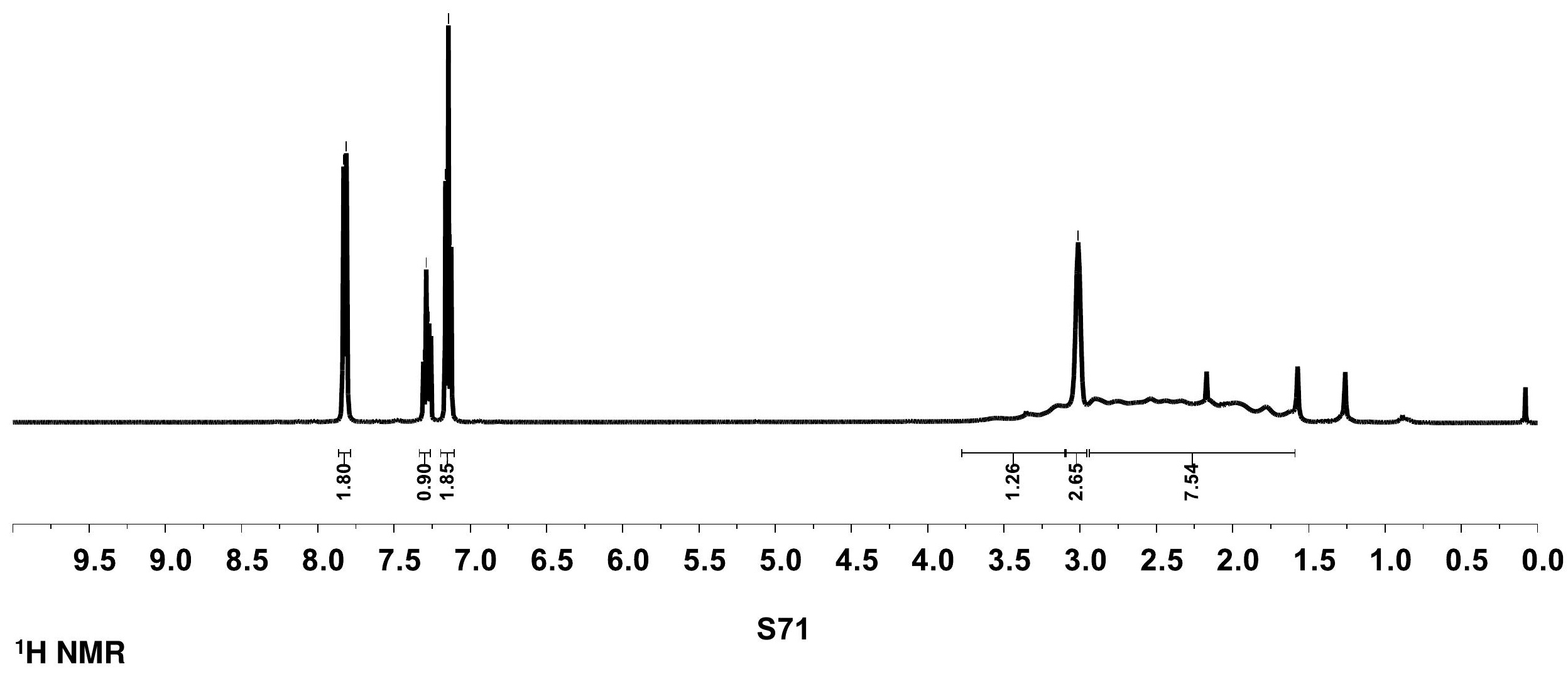




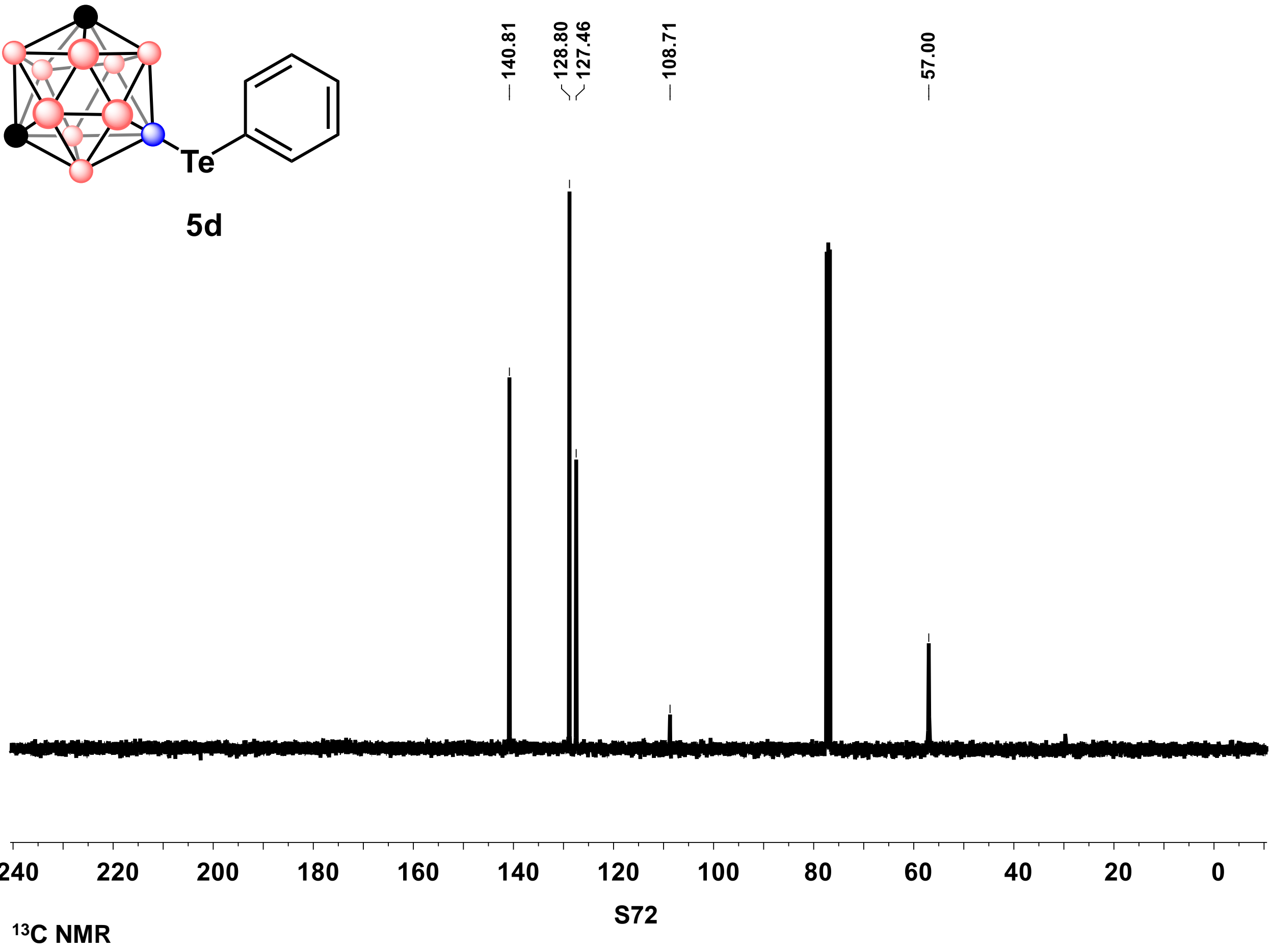




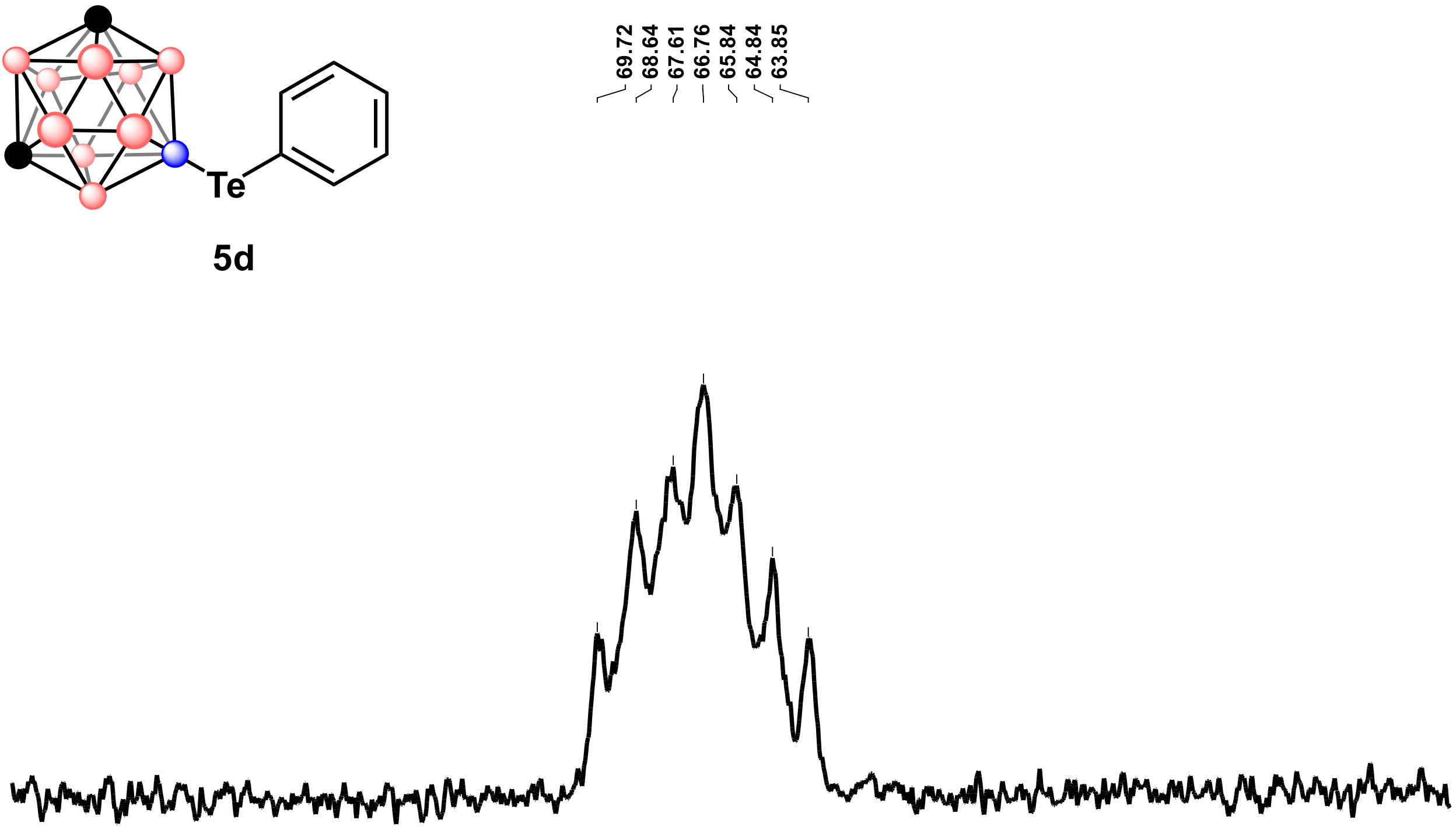




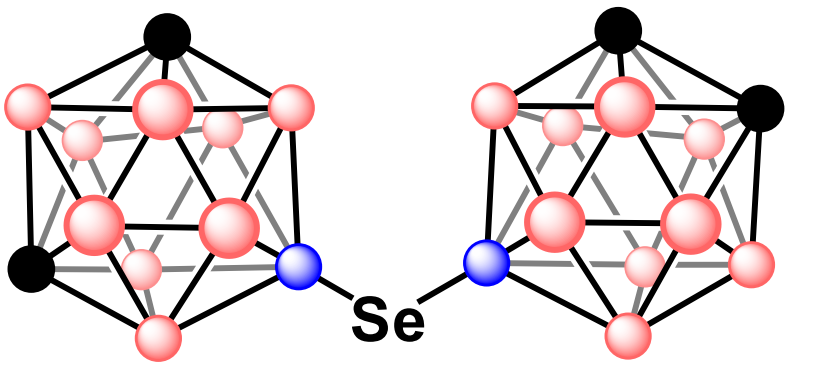

$5 e$

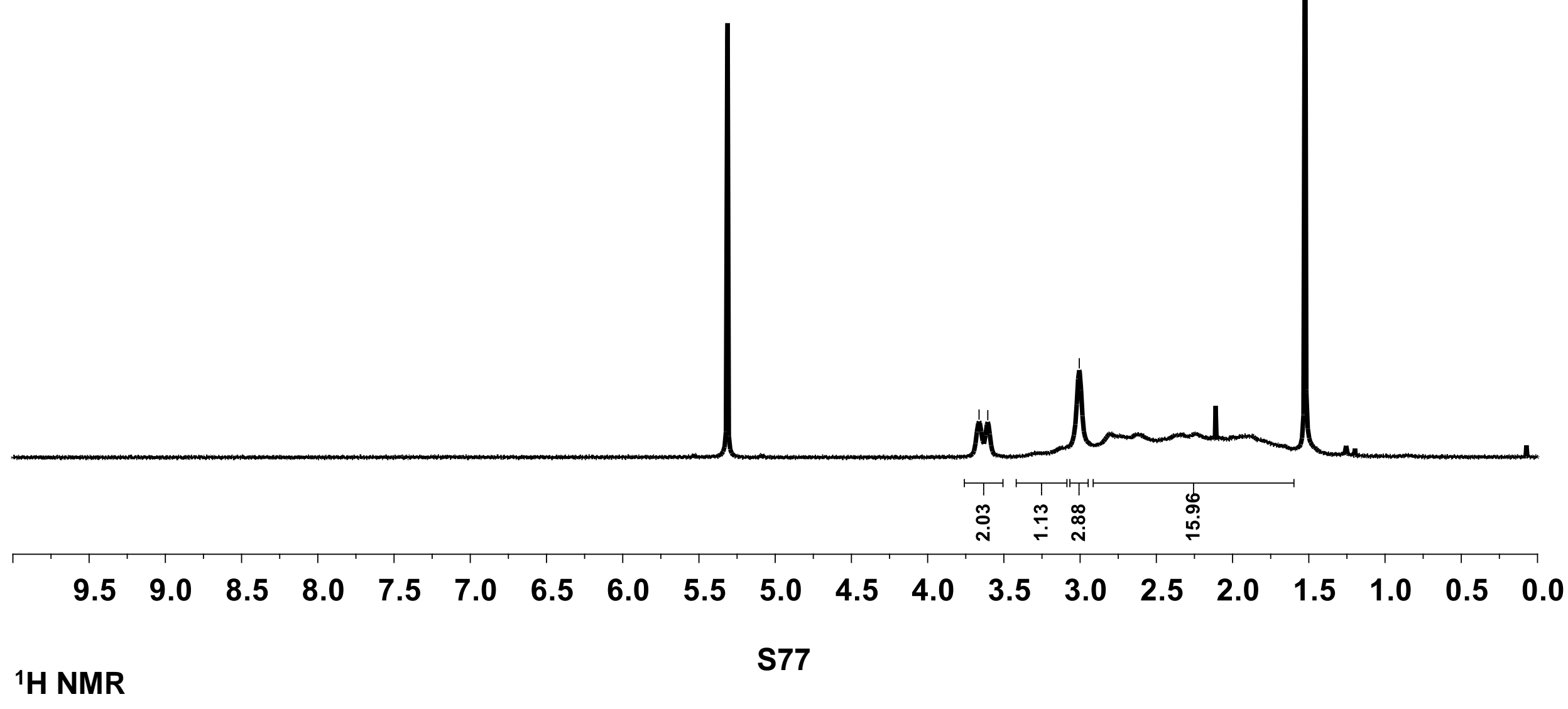


$5 e$

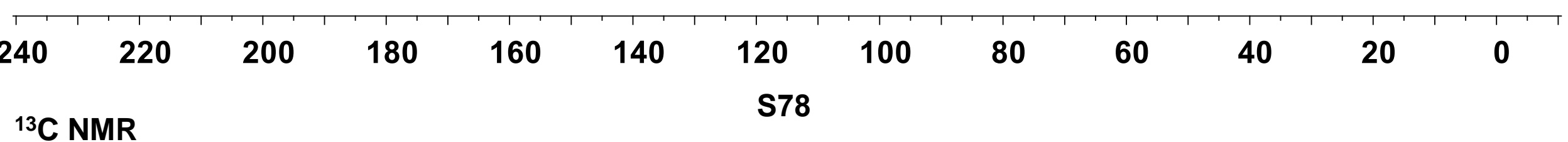




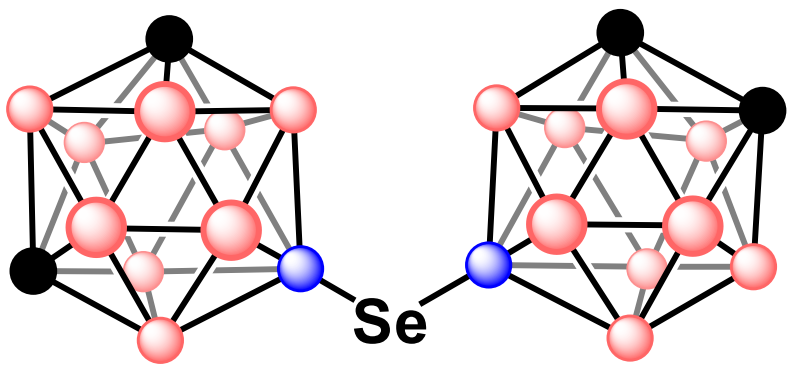

$5 e$

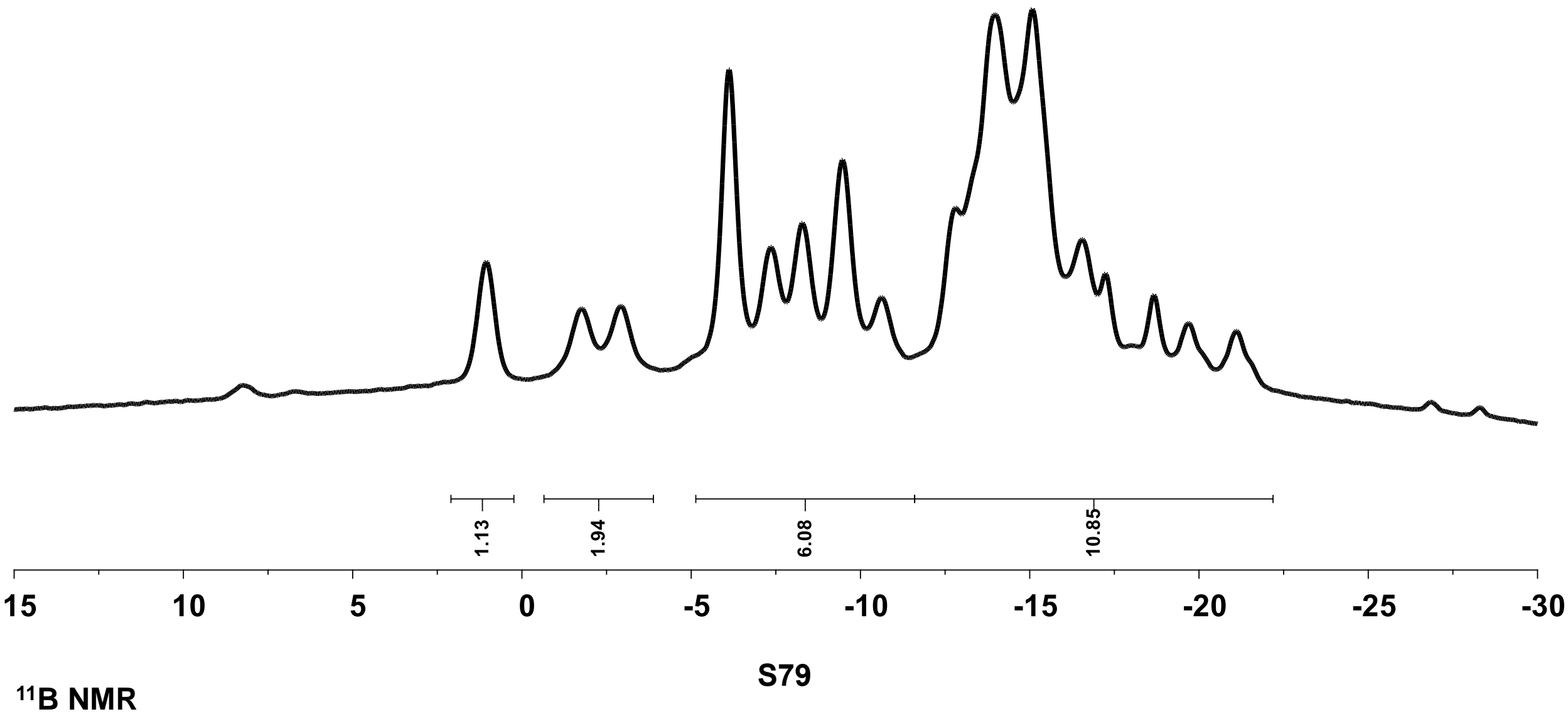




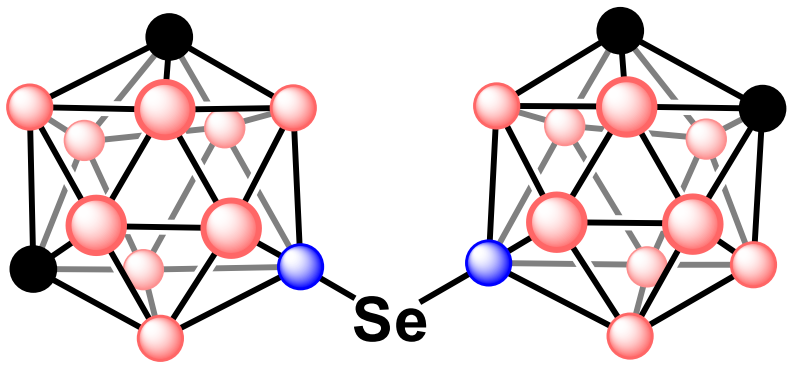

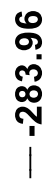

$5 e$
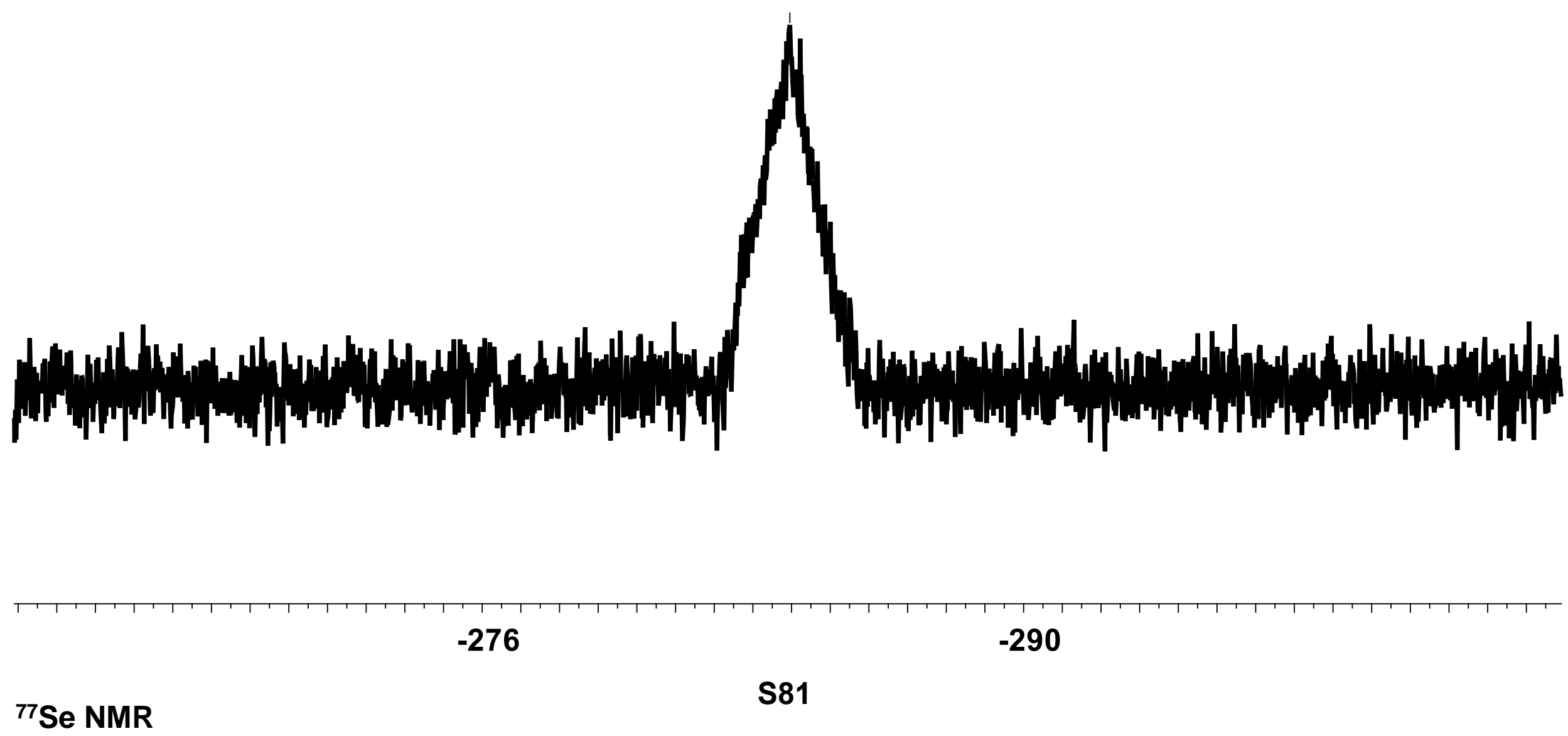


\section{$5 e$}
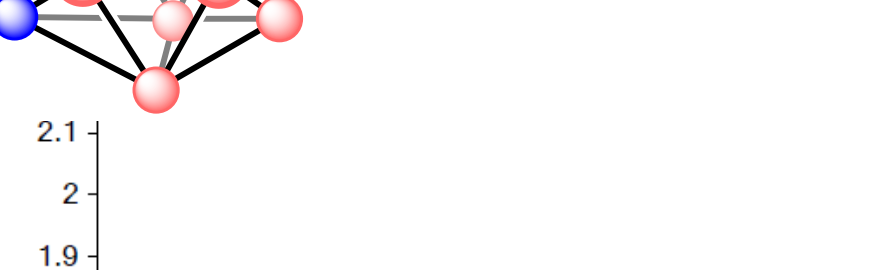

1.8

1.7

1.6

1.5
1.4

1.3

1.2
1.1 0.

0.8

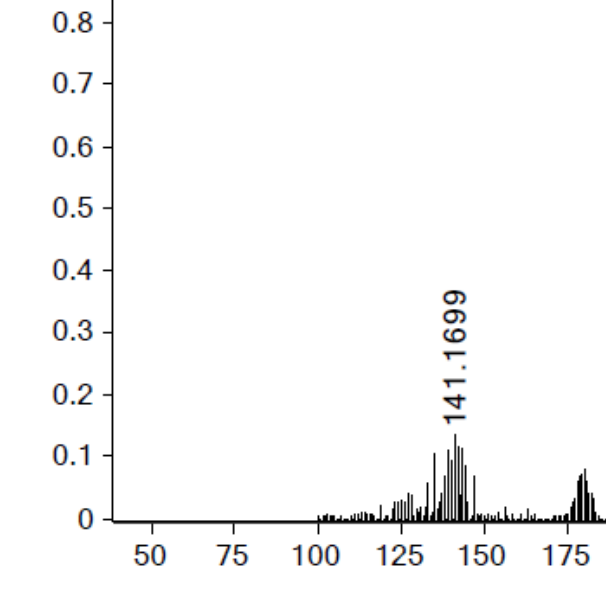

HRGC-MS

\section{S82}


กุ $\infty \infty N N N N N N N$

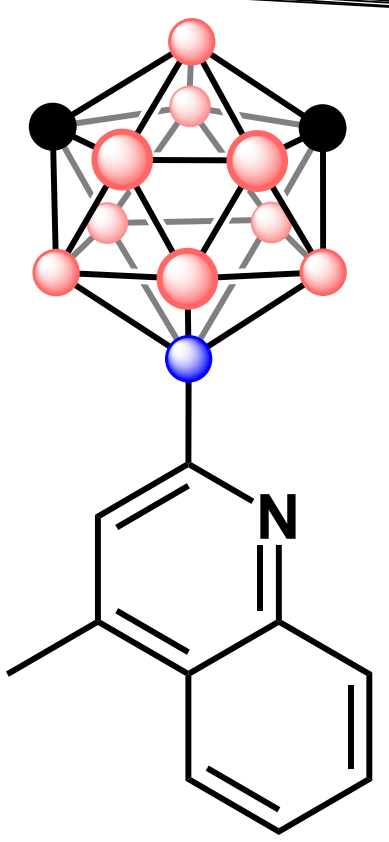

$5 f$ 


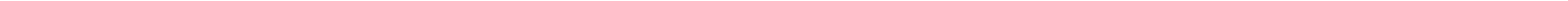




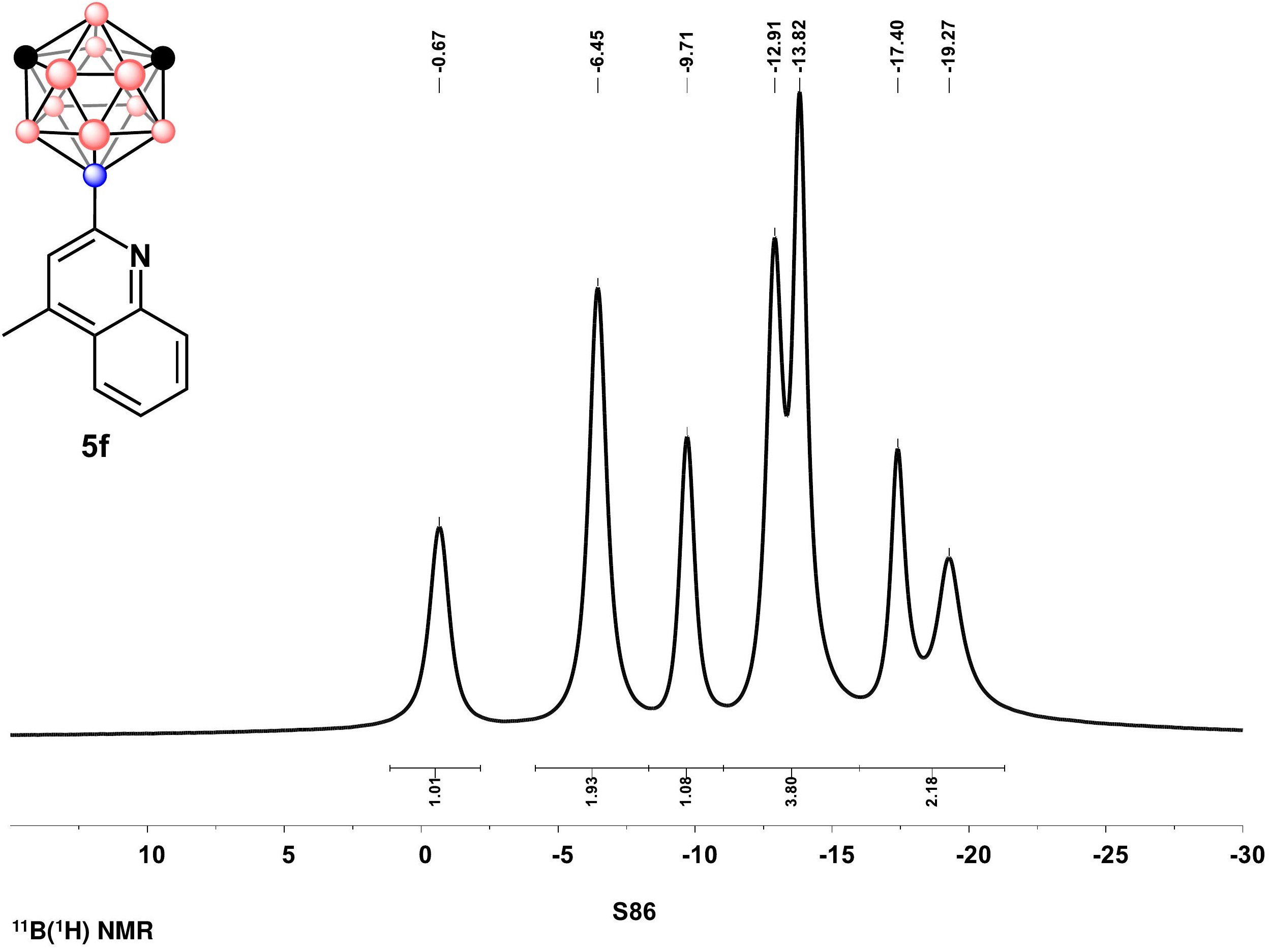




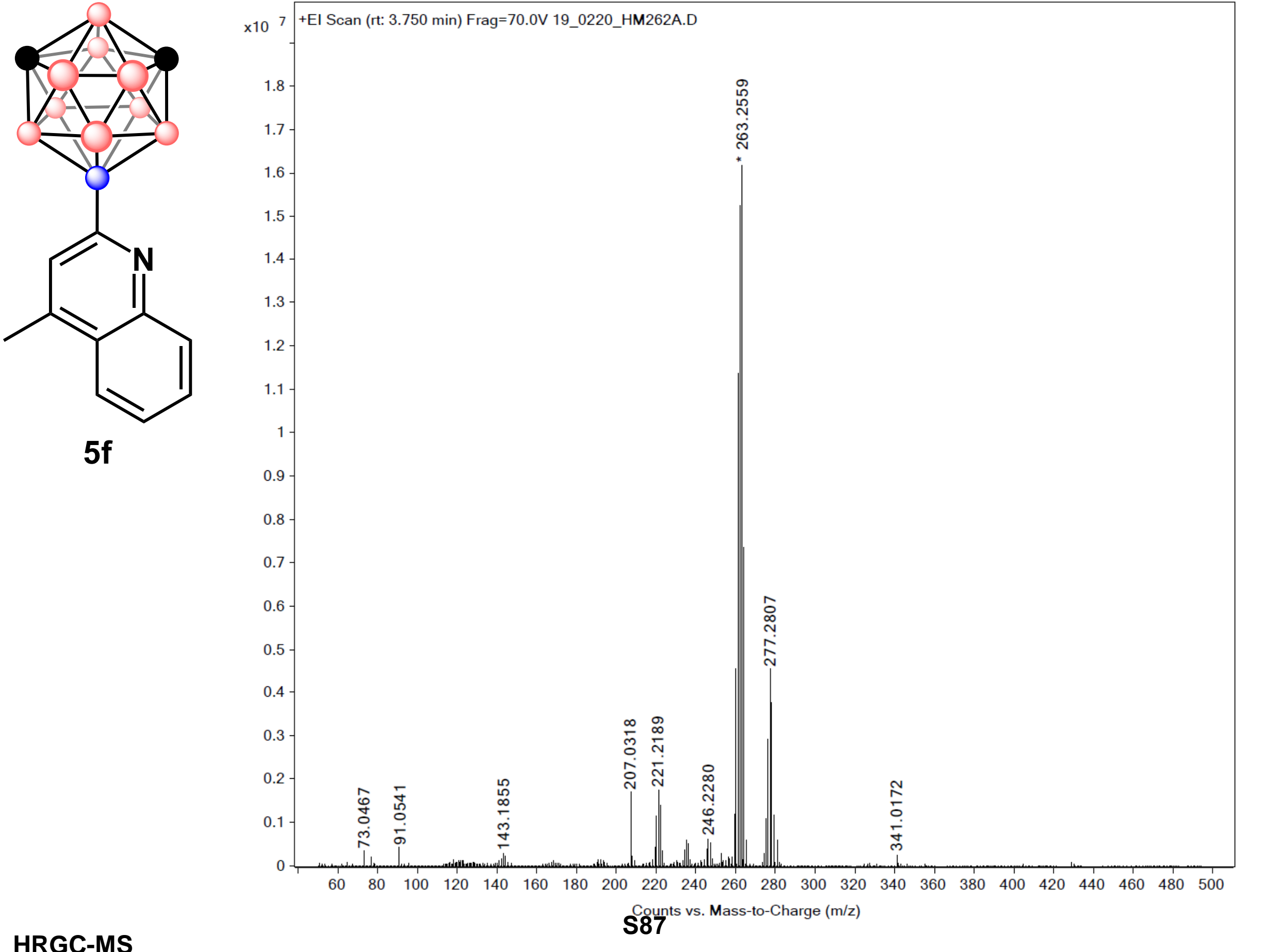

\section{HRGC-MS}




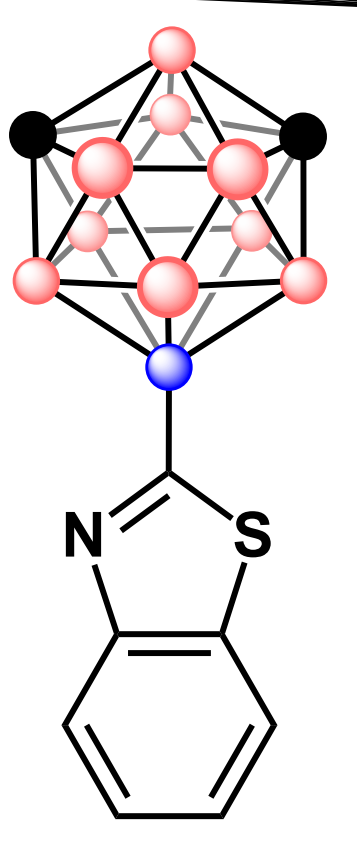

$5 g$

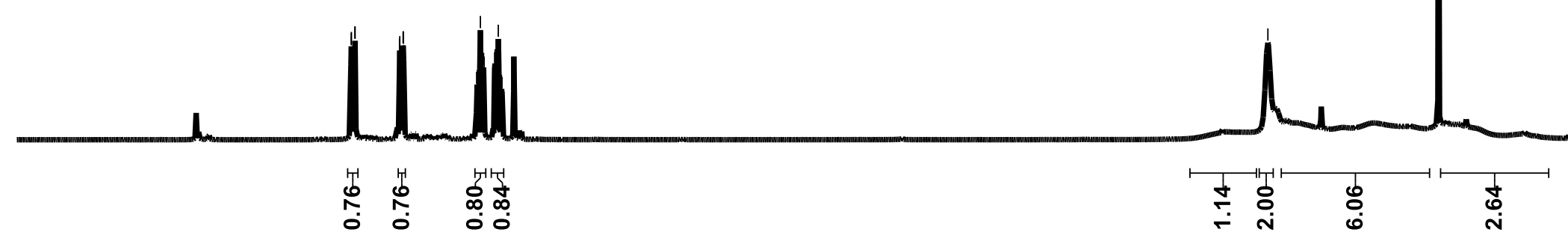

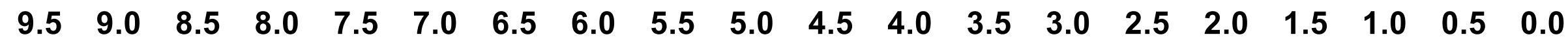
1H NMR 


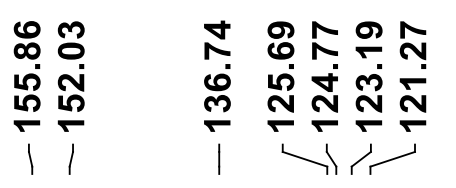

\section{$5 \mathrm{~g}$}

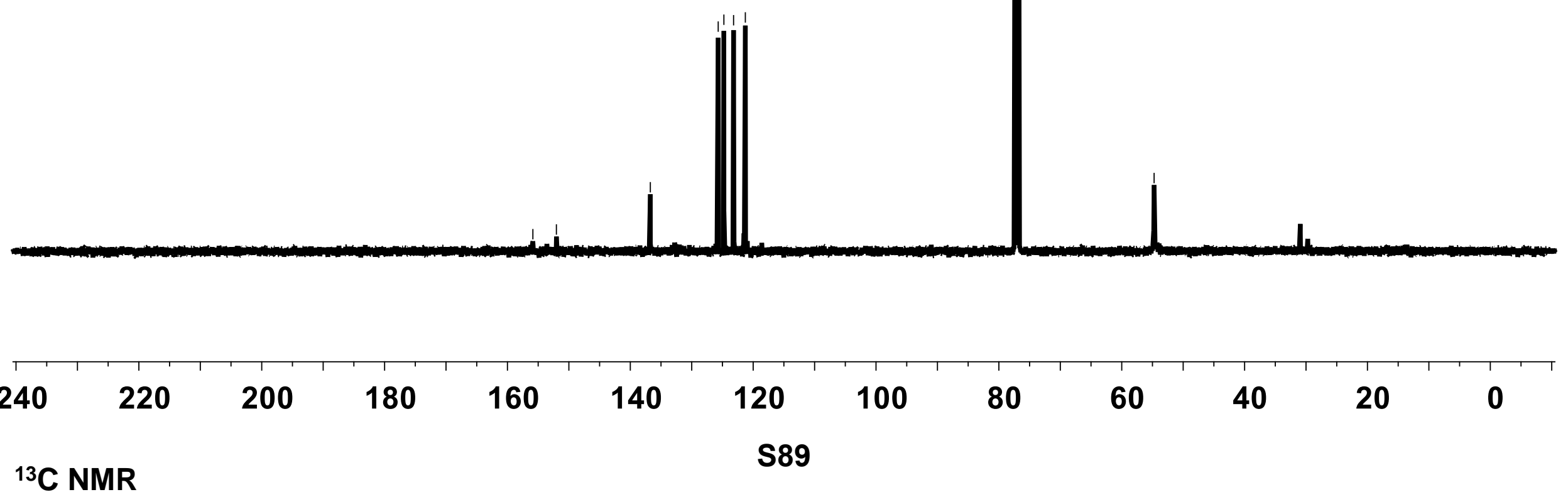




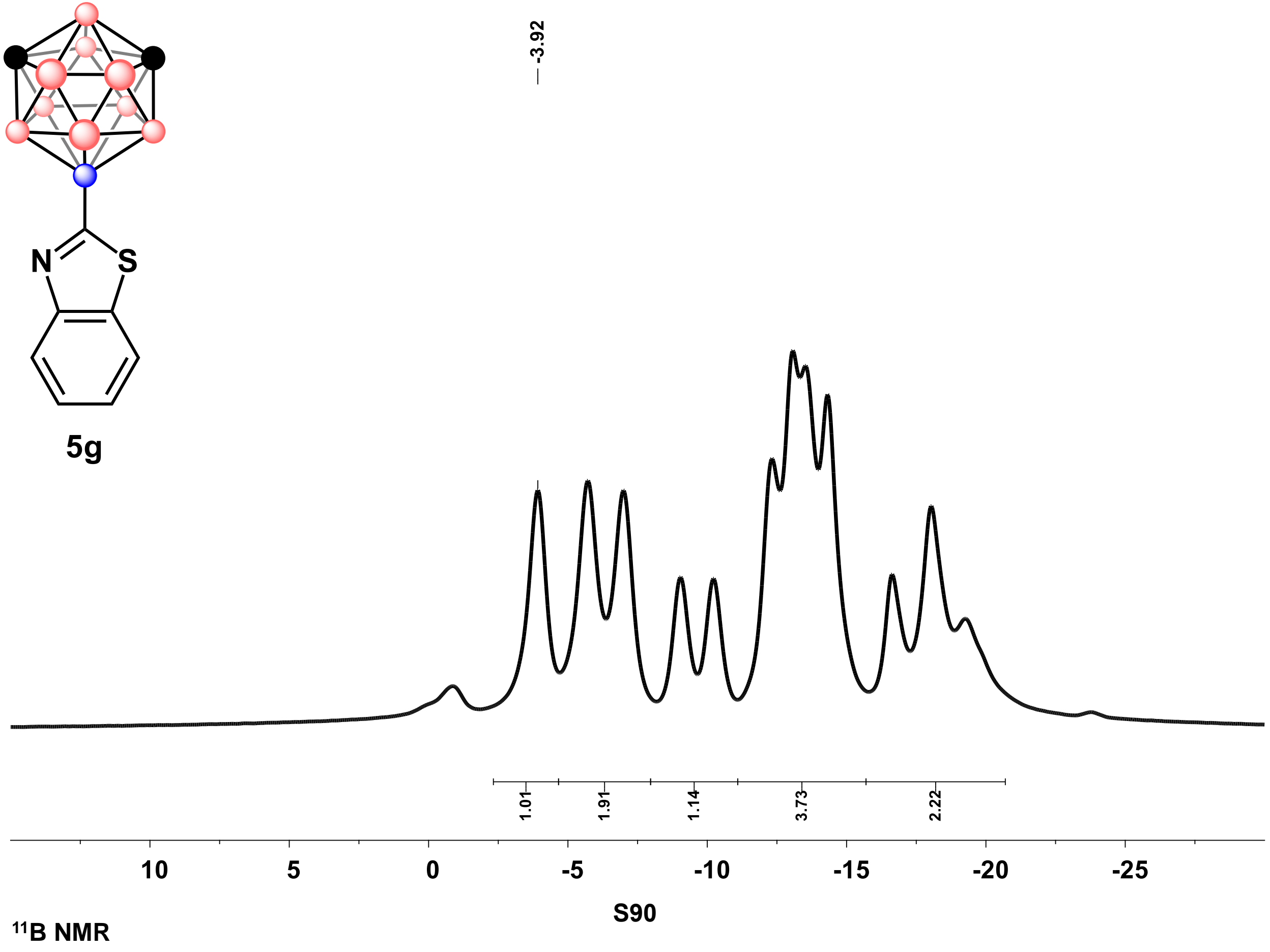



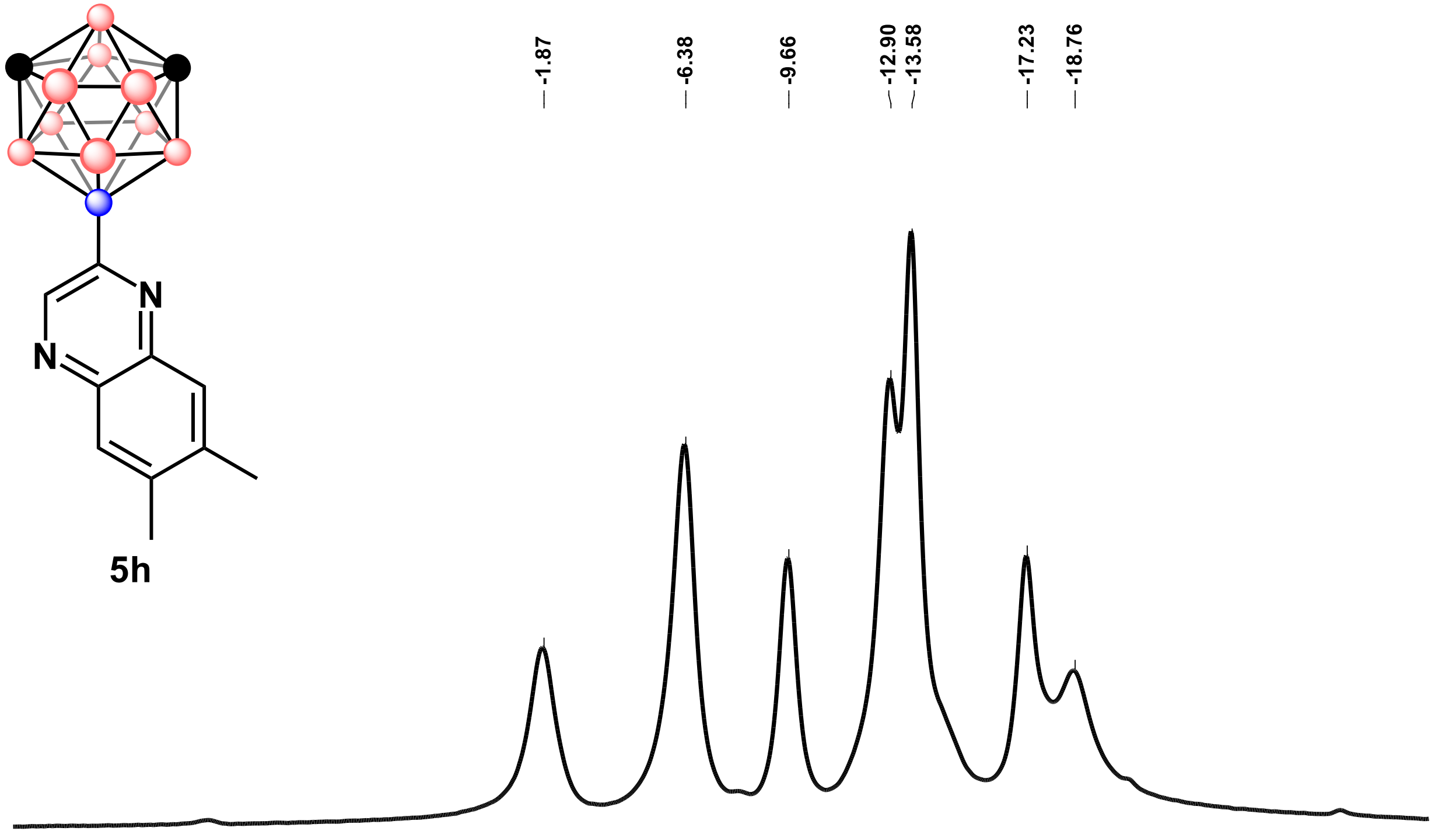

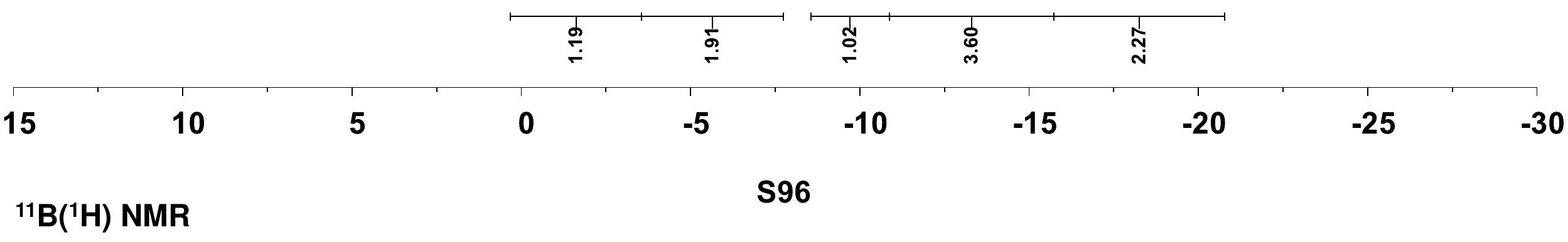




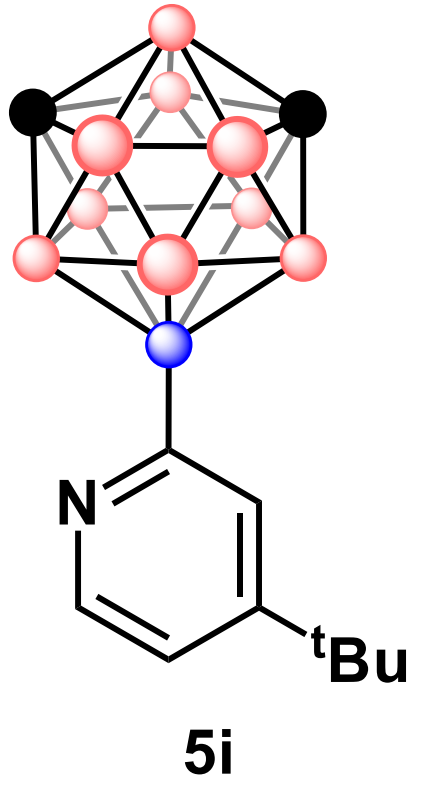

ْ̊ำ 


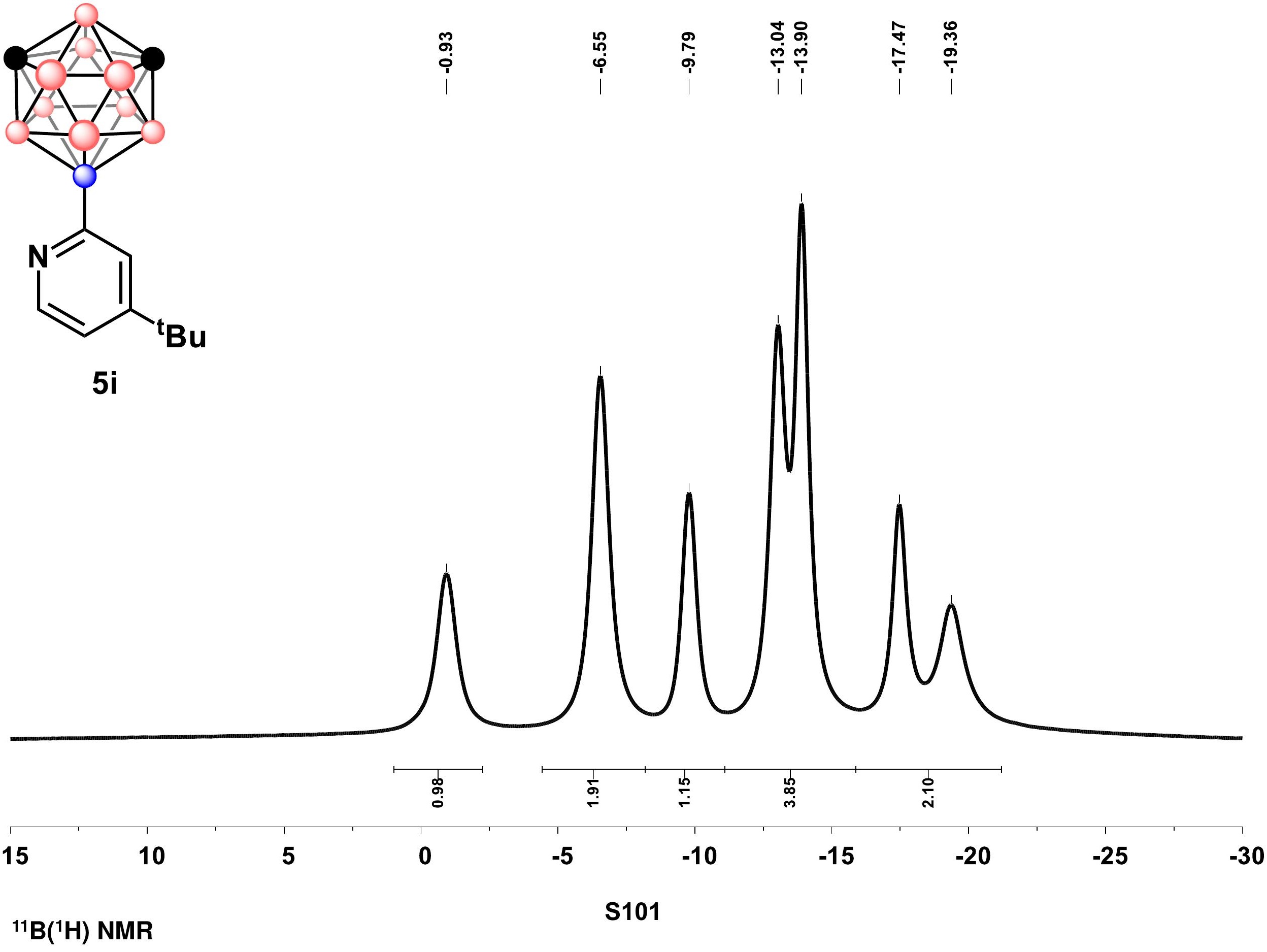



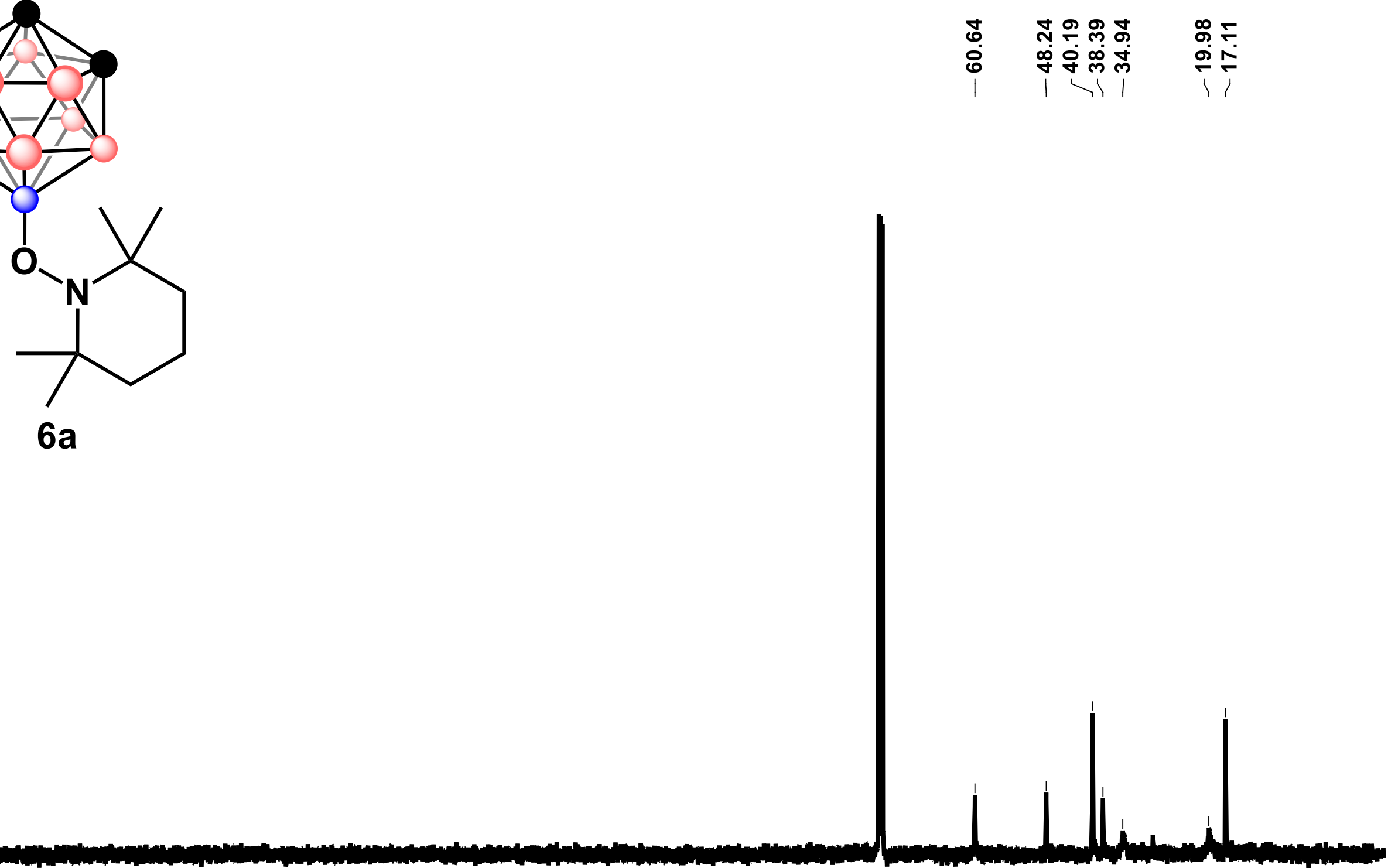

\begin{tabular}{|c|c|c|c|c|c|c|c|c|c|c|c|}
\hline 240 & 200 & 180 & 160 & 140 & 120 & 100 & 80 & 60 & 40 & 20 & 0 \\
\hline${ }^{13} \mathrm{C}$ NMR & & & & & & & & & & & \\
\hline
\end{tabular}




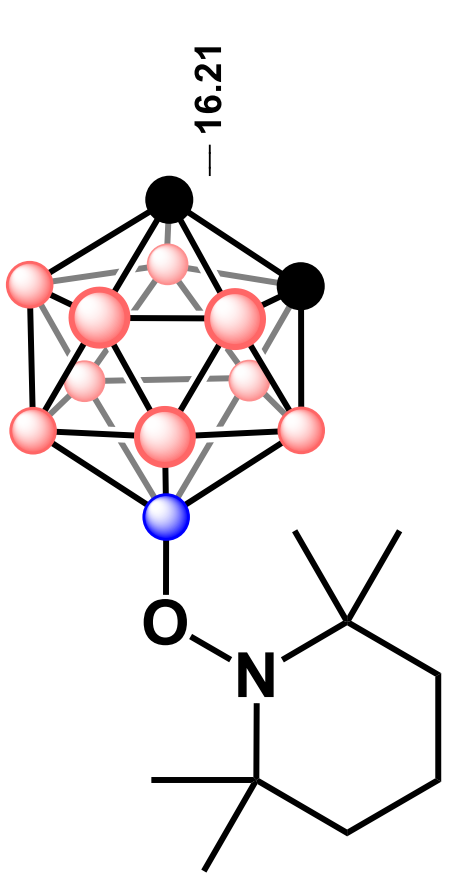

$6 a$

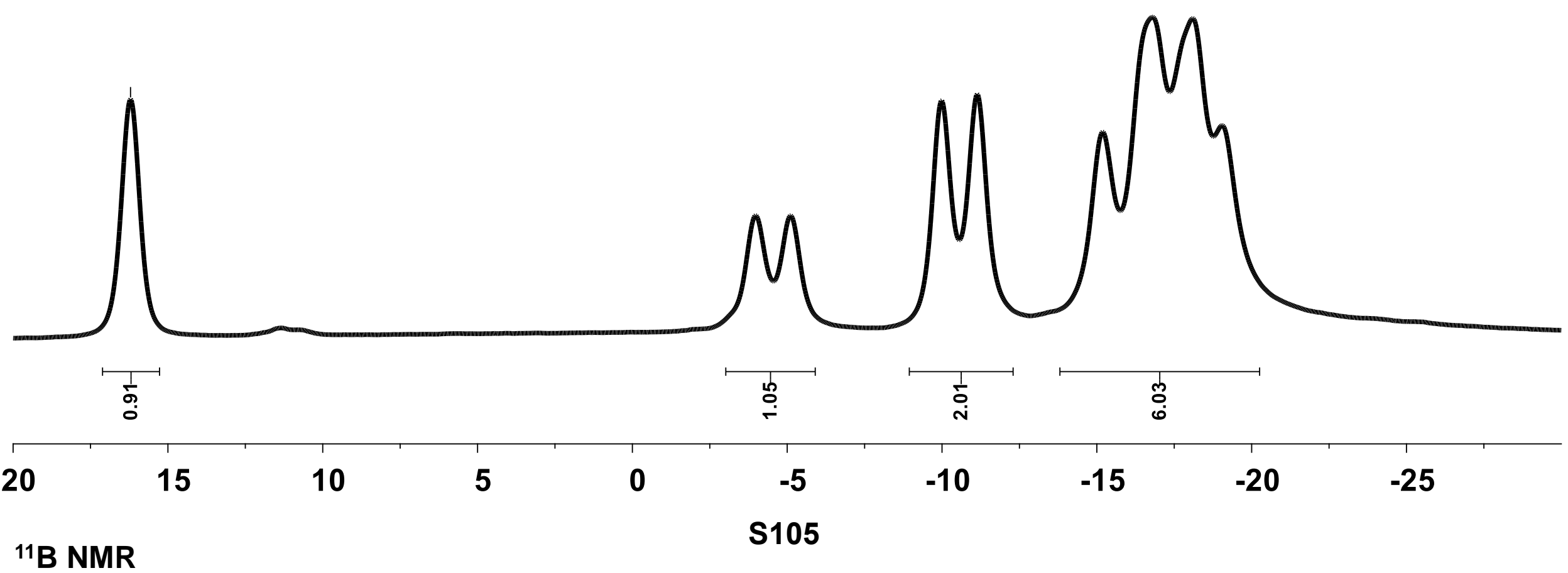




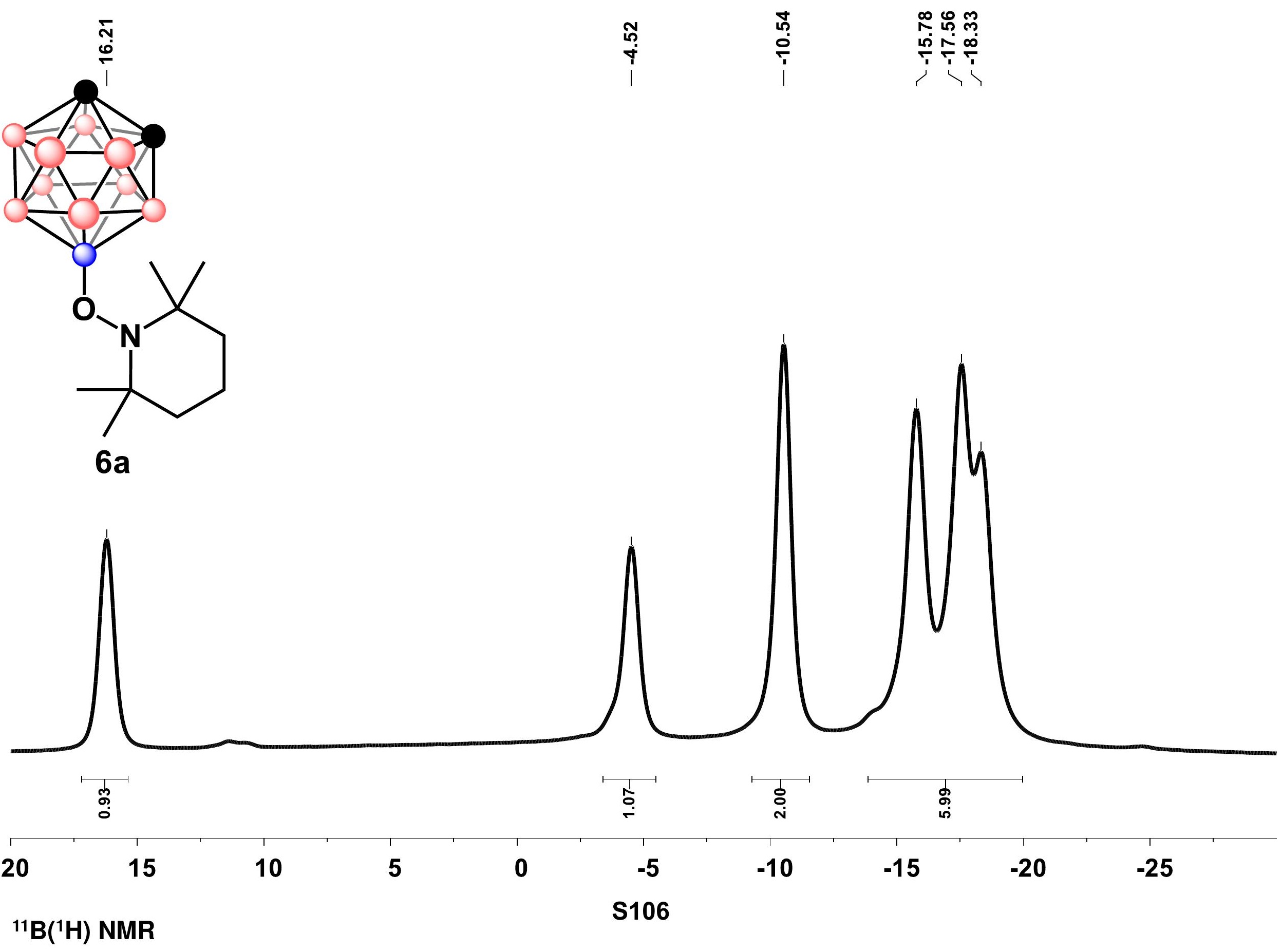




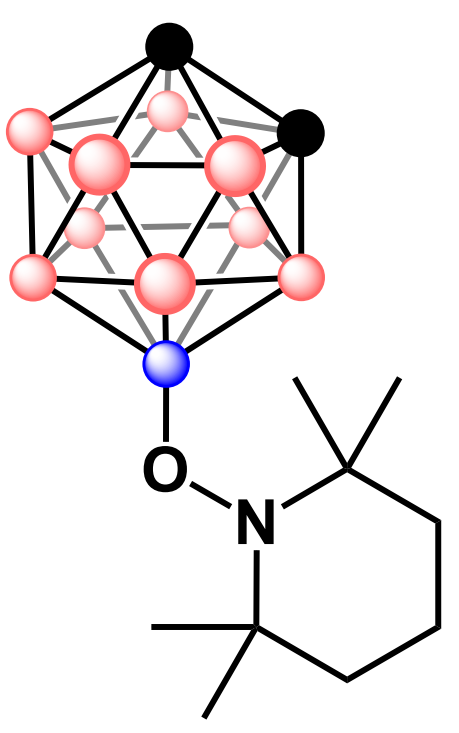

$6 a$

\section{HRGC-MS}




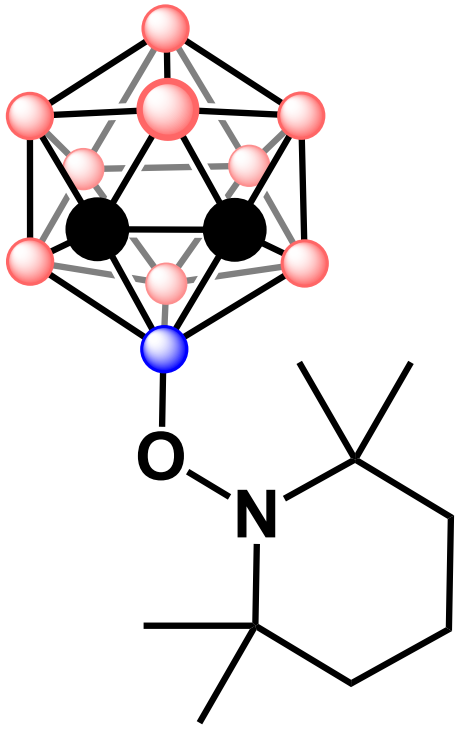

$6 b$

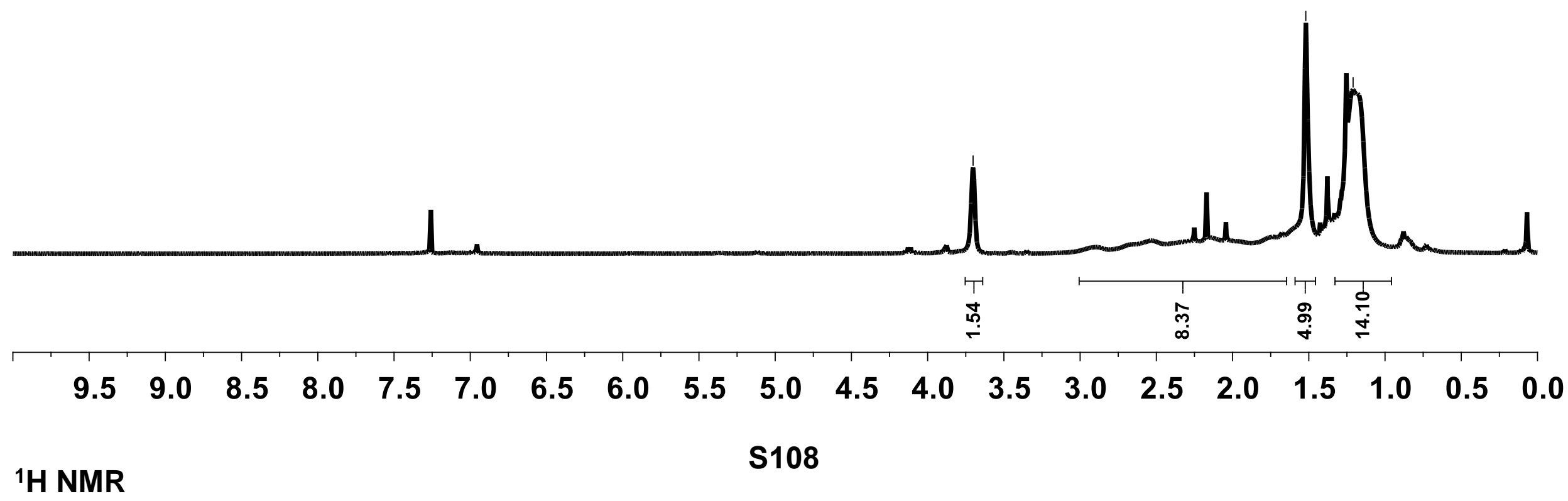



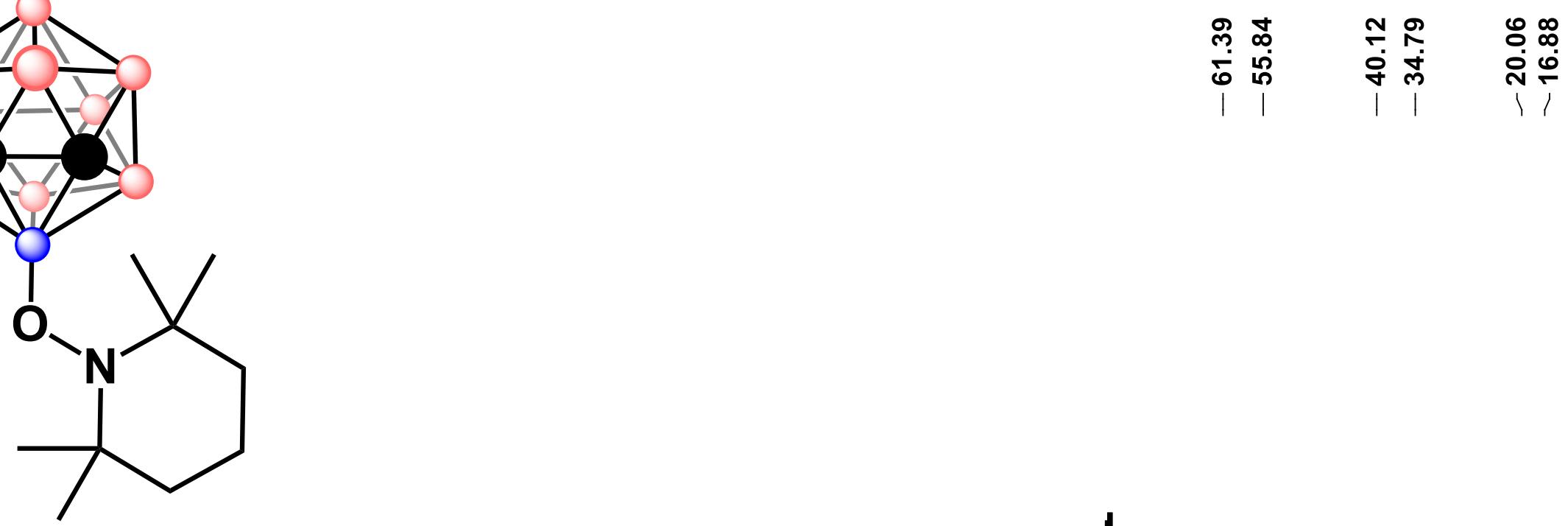

$6 b$

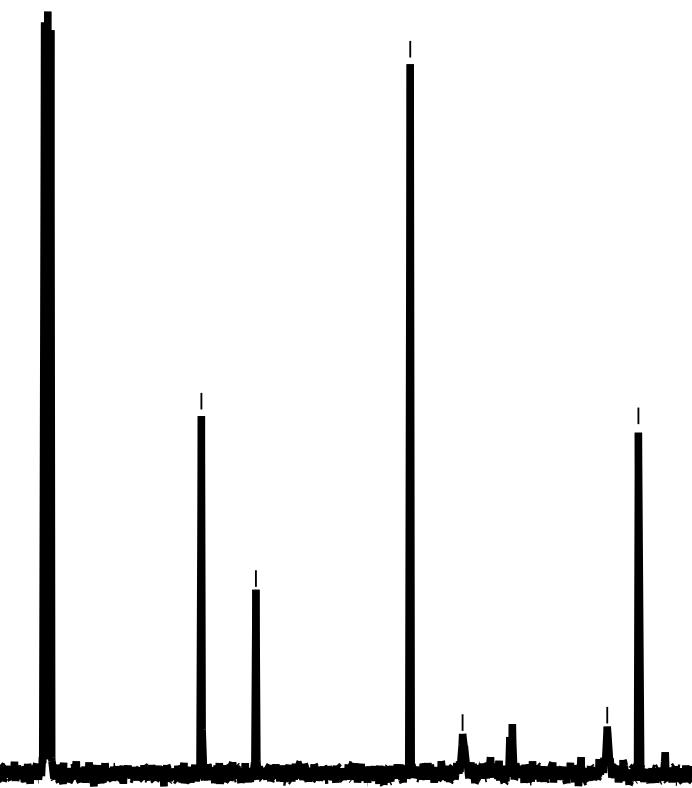

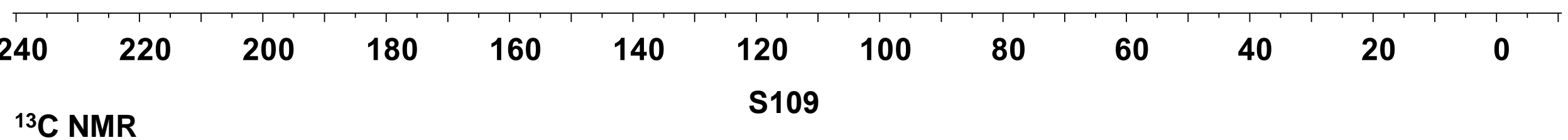




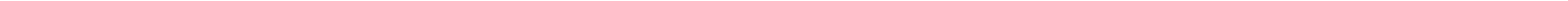




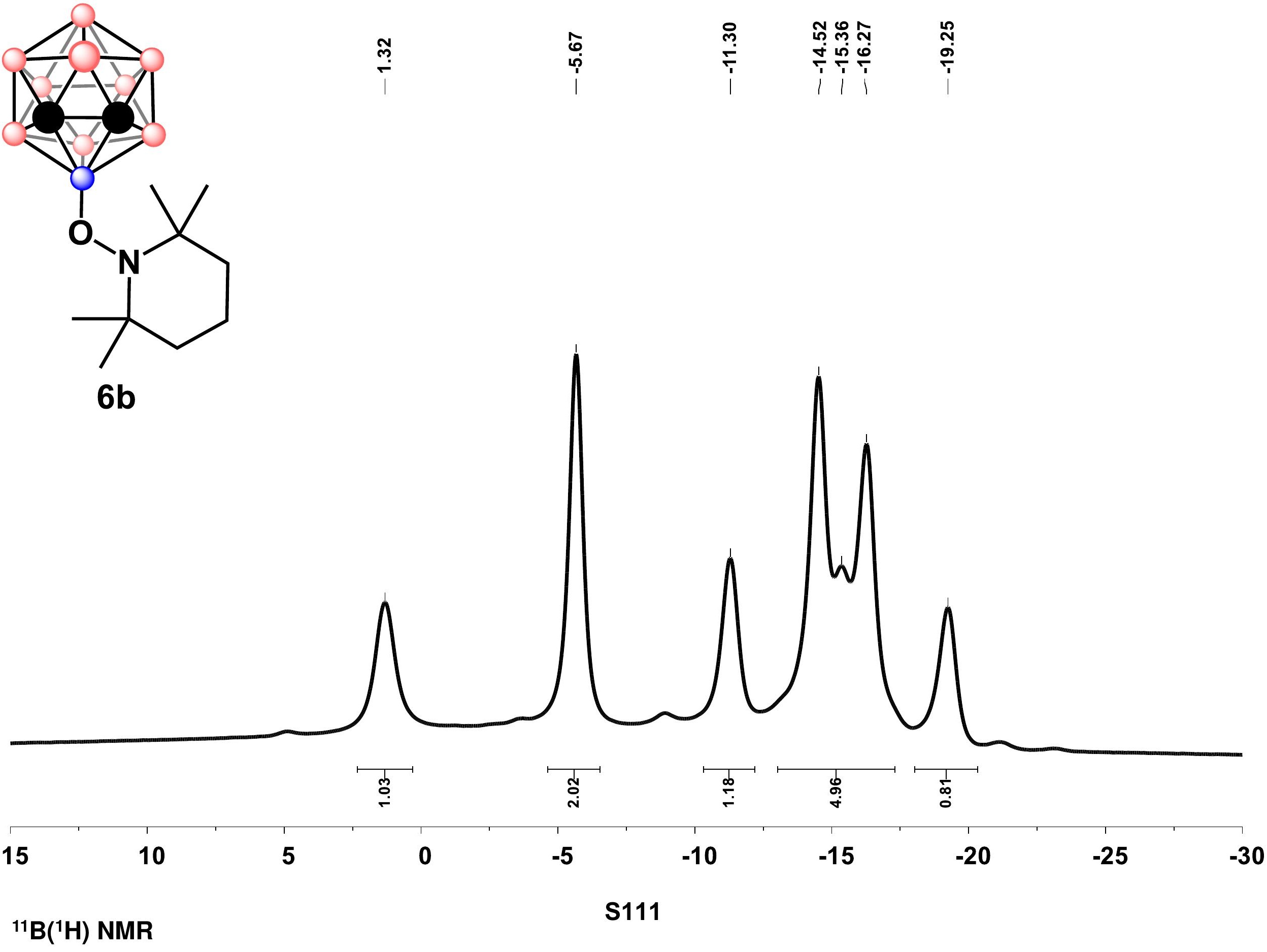




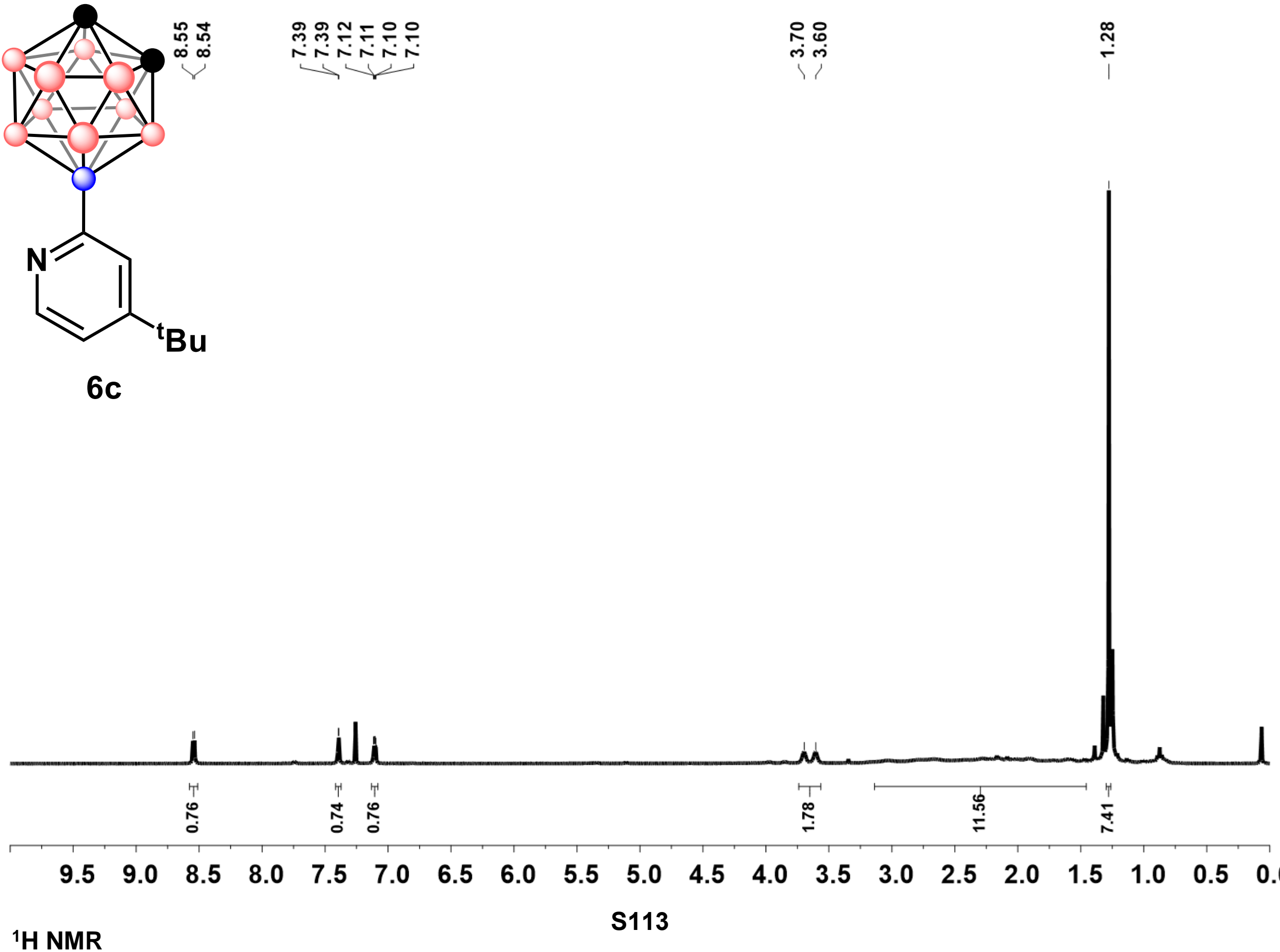




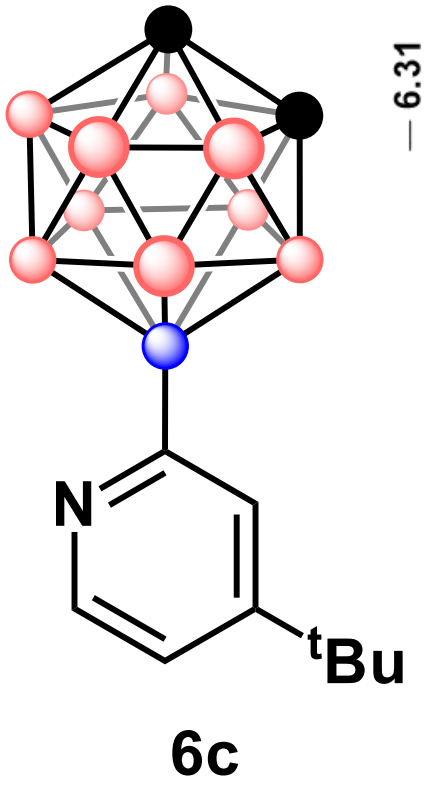

ڤं

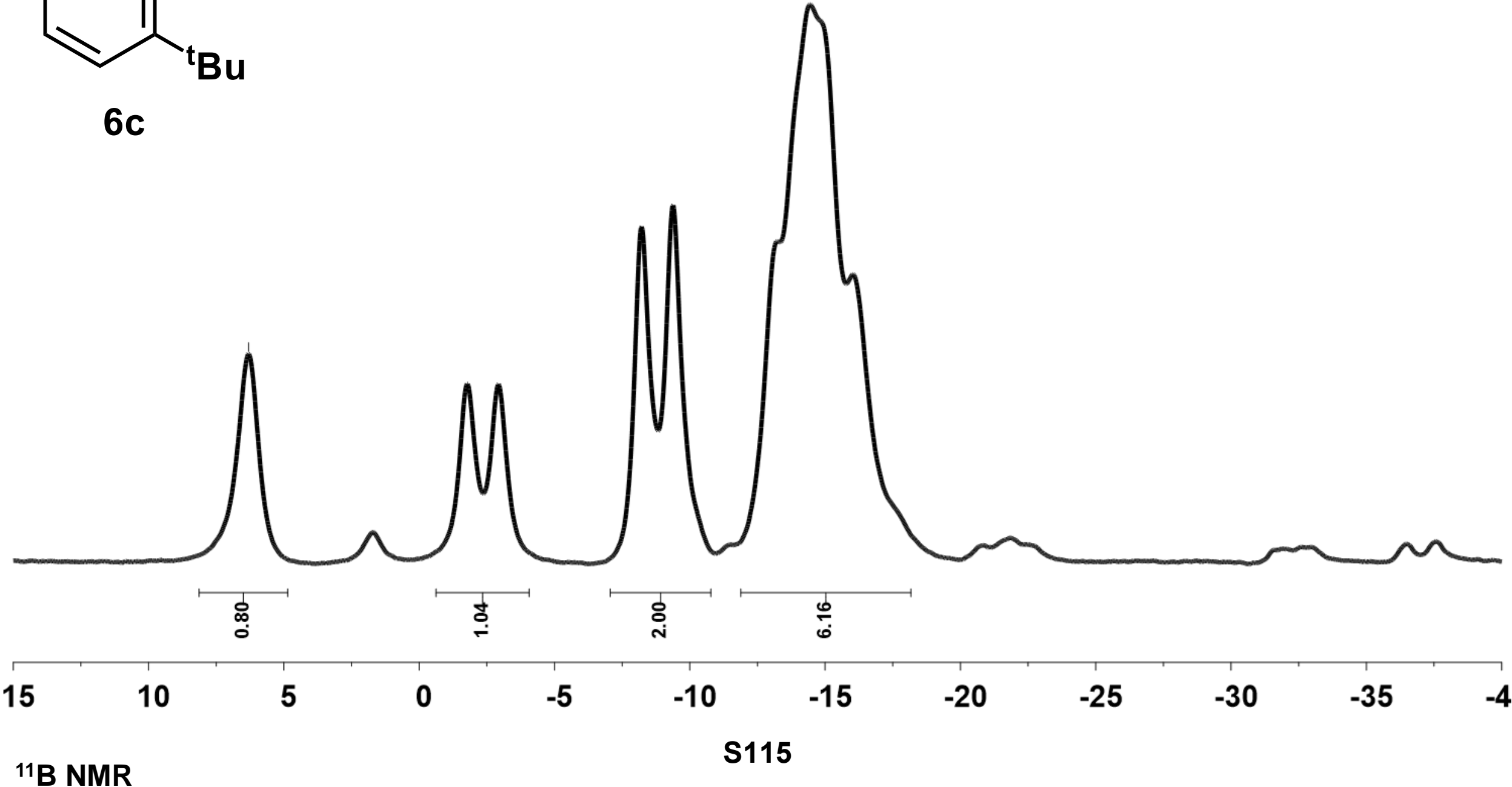




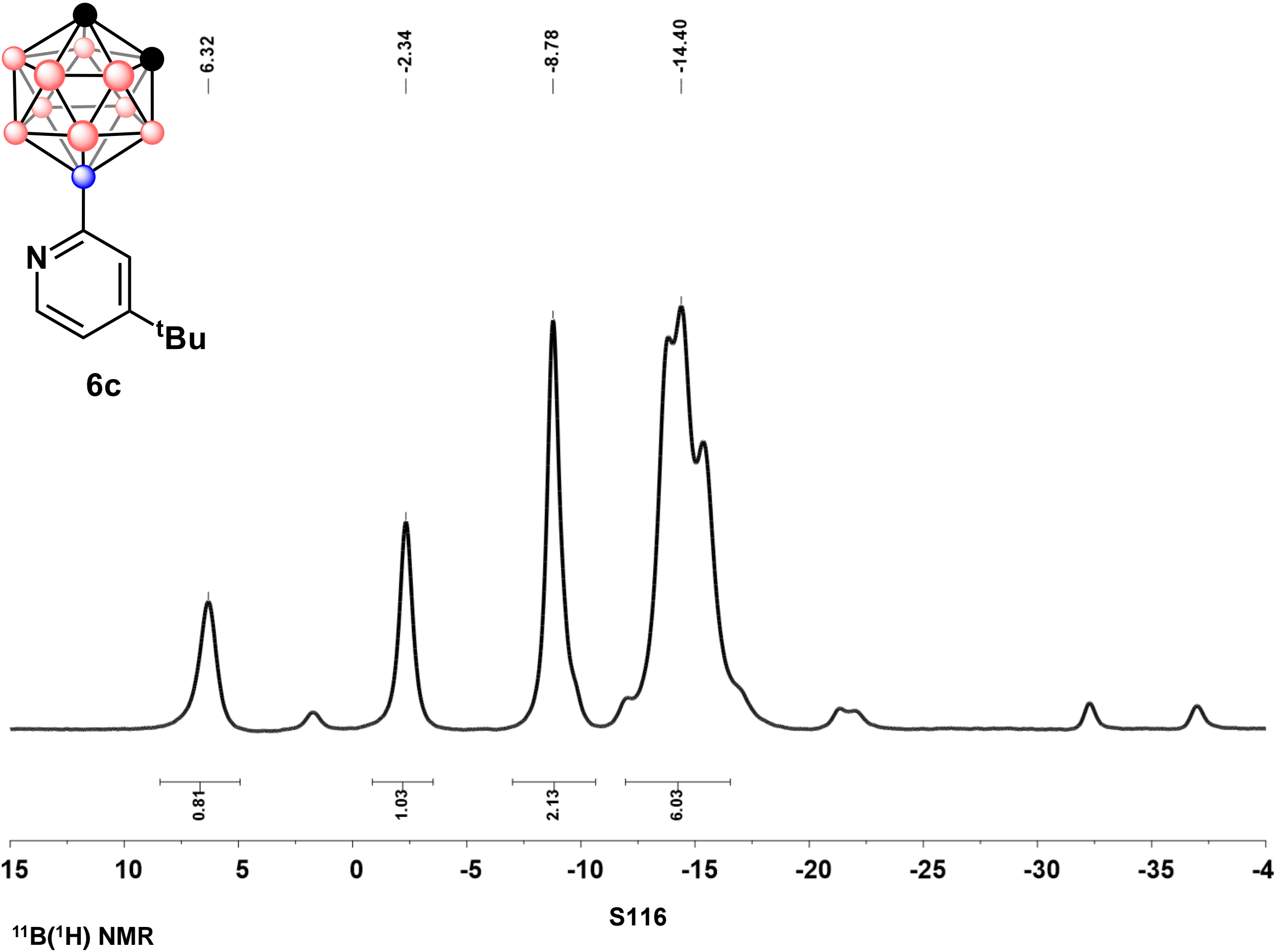


